\title{
MICHIGAN'S ENVIRONIMENTAL PROTECTION ACT OF 1970: A PROGRESS REPORT
}

\author{
Joseph L. Sax and Roger L. Conner
}

Table of Contents

I. INTRODUCTION . . . . . . . . . . . . . . 1004

II. Status of the Cases: A Brief Summary . . . . . 1007

III. Factors Affeecting Sugcess and Fallure . . . . 1010

A. Negotiated Solutions . . . . . . . . . . 1010

B. Politically Volatile Controversies . . . . . . 1014

C. The Ambitious-Gase Problem . . . . . . . 1017

IV. INTERPLAY BetWEen the EPA AND the AdMINISTRATIVE Process . . . . . . . . . . . . . . . 1019

A. Primary Jurisdiction . . . . . . . . . 1019

B. Augmentation of the Enforcement Process . . . 1027

V. JudictaI RESPONSE . . . . . . . . . . . 1031

A. Cases Tried on the Merits . . . . . . . . . 1031

1. Payant v. Department of Natural Resources . . 1031

2. Muskegon County v. Environmental Protection Organization . . . . . . . . . 1035

3. Crandall ข. Biergans . . . . . . . . . 1037

4. Tanton $v$. Department of Natural Resources 1038

5. Lakeland Property Owners Association v. Township of Northfield . . . . . . . . . . 1041

B. Restraining Orders and Preliminary Injunctions 1042

VI. IMPACT OF THE EPA ON ADMINISTRATIVE AND IndusTRIAL BEHAVIOR . . . . . . . . . . . . 1050

VII. Questions of Statutory Construction . . . . . 1054

A. The EPA as a Source of Substantive Law . . . . 1054

1. Introduction . . . . . . . . . . . . 1054

2. The Public Service Commission . . . . 1055

3. Eminent Domain . . . . . . . . . 1058

4. Roberts v. Michigan . . . . . . . . . 1059

5. Relation of the EPA to Other Statutes . . . 1060

B. Constitutionality of the EPA . . . . . . . . 1064

C. Intervention in EPA Cases . . . . . . . . 1069

D. Jurisdiction and Venue . . . . . . . . . 1072

E. Security Bonds . . . . . . . . . . . . 1076

VIII. Conclusion . . . . . . . . . . . . . . . 1080

[1003] 


\title{
MICHIGAN'S ENVIRONIMENTAL PROTECTION ACT OF 1970: A PROGRESS REPORT
}

\author{
Joseph L. Sax* and Roger L. Conner**
}

It is true that the Natural Resources Commission, upon my recommendation, approved construction. . . . It is likewise true that suit has been brought under the Environmental Protection Act by persons who disagree with that decision. The Act-one of the landmark pieces of environmental legislation in the nation-was passed for precisely that reason; to allow dissenting citizens an opportunity to register their dissents in court. Even though we have been madc the defendants in this suit, we welcome it as an expression of public interest in the environment, and another step toward redefining the law so that we can better interpret the wishes of the people. -Ralph A. MacMullen, Director, Michigan Department of Natural Resources†

\section{INTRODUCTION}

$\mathrm{T}$ THE Michigan Environmental Protection Act of 1970 (EPA) ${ }^{1}$ represents a departure from the long-standing tradition under which control of environmental quality has been left almost exclusively in the hands of regulatory agencies: it gives to ordinary citizens an opportunity to take the initiative in environmental law enforcement.

The statute is uncharacteristically brief and plain-spoken. It authorizes any person to bring suit against either a public agency or private entity for declaratory or equitable relief to protect the "air, water and other natural resources and the public trust therein from pollution, impairment or destruction."2 Once the plaintiff has demonstrated that such harm has occurred or is likely to occur, the defendant may prevail only if he can demonstrate affirmatively that there is "no feasible and prudent alternative to defendant's conduct and that such conduct is consistent with the promotion of the public

* Professor of Law, University of Michigan. A.B. 1957, Harvard University; J.D. 1959, University of Chicago.-Ed.

* Second-year student at the University of Michigan Law School. Member, Michigan Air Pollution Control Commission.-Ed.

Our research for this study has been made possible by a grant from the Council on Law Related Studies, for which we are most grateful.

$\dagger$ Letter to the Editor, State Journal (Lansing), Jan. 28, 1972, at A-6, col. 6.

1. Mrch. Comp. LAws ANN. $\$ \$ 691.1201-691.1207$ (Supp. 1972). The full text of the EPA is reprinted as Appendix H. A brief legislative history of the Act appears in Note, Michigan's Environmental Protection Act: Political Background, 4 U. MrcH. J. L. REF. 358 (1970).

2. EPA § 2(1), Mich. CoMP. LAws ANN. § 691.1202(1) (Supp. 1972).

[1004] 
health, safety and welfare ...."3 If regulatory proceedings are available to pass upon the defendant's conduct, the court is authorized -but not required-to remit the parties to such proceedings, ${ }^{4}$ and is, in any event, empowered to grant equitable relief pending the outcome of such proceedings to protect the rights recognized by the Act."

Beyond giving private citizens the right to initiate or participate in environmental proceedings, the EPA is a significant departure in another way. It enlarges the role of courts because it permits a plaintiff to assert that his right to environmental quality has been violated in much the same way that one has always been able to claim that a property or contract right has been violated. ${ }^{6}$ In taking this step, the legislature reduced the broad discretion that regulatory agencies formerly had. Previously these agencies had been given a sweeping mandate to enforce environmental standards as they thought best, and their decisions were subject to judicial review only for arbitrary and abusive use of their authority or for violation of explicit statutory language. Now these agencies must be prepared to defend themselves against charges that their decisions fail to protect natural resources from pollution, impairment, or destruction. ${ }^{7}$

This combination of increased private initiative, expanded judicial involvement, and restricted regulatory-agency authority, all brought together in Michigan's Environmental Protection Act, elicited considerable doubt: Was it unrealistic to expect private citizens and environmental groups, however well intentioned, to play a significant part in law enforcement-especially considering the technical complexity of the questions likely to be raised and the expense usually incurred in litigation? Would circuit judges be able to understand and deal with intricate environmental issues? Could court orders, issued case by case, significantly ameliorate environmental problems? Finally, would the regulatory agencies themselves find their well-developed programs subject to continual attacks in the courts?

3. EPA § 3(1), Mich. CoMr. LAwS ANN. § 691.1203(1) (Supp. 1972).

4. EPA \& 4(2), Mich. CoMp. LAws ANN. \& 691.1204(2) (Supp. 1972).

5. EPA \& 4(2), Mrch. Comp. LAws ANN. § 691.1204(2) (Supp. 1972).

6. Thus the EPA both recognizes and makes enforceable a new substantive right. The Act implements art. IV, $\$ 52$ of the Michigan Constitution of 1963:

The conservation and development of the natural resources of the state are hereby declared to be of paramount public concern in the interest of the health, safety and general welfare of the people. The legislature shall provide for the protection of the air, water and other natural resources of the state from pollution, impairment and destruction.

7. The EPA governs private conduct as well as the conduct of state agencies. 
Because these questions are difficult and important, it seemed desirable to follow the Act during its early days and to try to determine how well, or how ill, it fulfilled the expectations of those who worked assiduously for its enactment. We have attempted to monitor all the litigation instituted under the Act during its first sixteen months. ${ }^{8}$ What follows is a report on what we have learned. ${ }^{\circ}$

It did not take us long to discover that a comprehensive evaluation of even one statute within a single state over a brief period of time was beyond our competence. Plainly, a statute's influence is not limited to lawsuits actually instituted. Industrial and administrativeagency behavior may be modified by the fear of a lawsuit and its attendant publicity; developments in one suit may bring about institutional changes of behavior in similar matters; and, of course, it is never possible wholly to isolate the presence of a statute from the public atmosphere in which it was enacted. If there have been behavioral changes, it is not easy to identify them as the product of the EPA rather than as responses to increased public concern with environmental quality.

We made no effort to investigate systematically all the matters just mentioned. Such an inquiry would be useful, and we hope it can be undertaken at a later stage. We did, however, acquire some informal data about the general effects of the statute. ${ }^{10}$

To monitor suits filed, we regularly read daily and weekly Michigan newspapers, as well as bulletins and newsletters of environmental, industrial, and government organizations. We tried to attend all hearings on motions and trials on the merits; when this was not possible, we attempted to acquire stenographic transcripts or tapes. Files were also kept on newspaper publicity that the cases received. In addition we developed a state-wide network of informants, which included officials of citizen organizations, journalists, and attorneys, and we exchanged information with the Attorney General's office, which also maintained a list of suits filed. In March 1972 we sent a follow-up questionnaire to all lawyers involved in EPA cases. Our questions, with a summary of answers, appear in Appendix I.

8. See EPA \& 2(1), Mrch. Comp. Latws ANn. \& 691.1201(1) (Supp. 1972). The report is current to March 1, 1972. Additional information received after that date, but prior to publication, has been inserted.

9. One of the authors, Joseph L. Sax, drafted the original EPA. Both authors worked toward enactment of the bill. Obviously, we are interested parties. We have made no effort in this Article to conceal our own views, but we have tried to present an unbiased report on what has occurred.

10. See text accompanying notes $181-93$ infra. 


\section{Status of the Gases: A BRIEF SUMMARY}

At the time this Article was being written, no case had reached either the court of appeals or the supreme court.11 Thus every significant legal issue, including the Act's constitutionality, remains unresolved by appellate courts. ${ }^{12}$ This in itself is interesting and invites speculation about the way in which a statute like the EPA evolves.

Despite a much-invoked fear that enactment of the EPA would flood the courts with suits, only thirty-six cases have been filed in sixteen months, and they have been evenly distributed over that period, with two or three filed each month. ${ }^{13}$ The modest number of cases filed is neither cause for joy nor for gloom. It implies that both the proponents and opponents of the Act were wrong; the statute is not as easily accessible a tool as its supporters had hoped or its opponents had feared.

The cases have been widely spread among the circuit courts in the state. Only two counties have had more than two cases filed.14 In one sense, this dispersion of cases is caused by the provisions of the statute, for the EPA limits plaintiffs to the circuit court "where the alleged violation occurred or is likely to occur."15 Plaintiffs have not wholly been deprived of choice of forum, however, in those cases in which a state agency is a defendant and the issuance of a

11. But see note 170 infra. The status of the cases is set out in Appendices F \& G infra.

12. The constitutionality of the EPA is discussed at notes 24466 infra and accompanying text. See also text at note 71 infra.

13. See Appendix A infra. Cases cited in this Article are referred to by name only; other citation details are contained in Appendix A. Two of the thirty-six matters are not court cases, but are administrative-agency interventions. Three new cases have been filed since this Article was completed. (1) Irish v. Green, No. 14306-C (Cir. Ct., Ingham County, filed April 12, 1972) challenges a subdivision development in West Traverse Township, Emmet County. A change of venue was granted to Emmet County, where the file number is No. 162-3 (Civil). (2) Wayne County Health Dept. v. City of Dearborn, No. 203110-R (Cir. Ct., Wayne County, filed April 1972) seeks a preliminary injunction to stop open burning of trash pending the outcome of the lawsuit. A hearing was held April 7, 1972, and continued to May 5, 1972, when testimony was taken. An order has not yet been issued. (3) McPhail v. Corps of Engineers, No. 205-941R (Cir. Ct., Wayne County, filed April 24, 1972) challenges a channelization project on the Rouge River. The case was removed to the United States District Court for the Eastern District of Michigan where the file number is 38203 .

A fourth case, just discovered, Braun v. Detroit Edison Co., No. 5552. (Cir. Ct., Washtenaw County, amended complaint filed Jan. 18, 1972) challenges condemnation proceedings for a transmission line easement. See text accompanying notes 220-24 infra.

14. See Appendix A infra.

15. EPA \& 2(1), Mich. COMP. LAws ANN. § 691.1202(1) (Supp. 1972). 
permit or license is an alleged wrong. ${ }^{16}$ In such cases, plaintiffs may sue at either the state capital or at the place where damage to the environment occurs. Thus four cases have been filed in the circuit court for Ingham County, the site of the State Capital, in three of which the conduct of a state regulatory agency has been at issue. The only other circuit in which more than two cases have been filed is Wayne County, which includes Detroit; there the Wayne County Health Department has been the most frequent user of the Act.

Public agencies have been plaintiffs under the Act more often than was anticipated. Government entities, including cities and counties, have been plaintiffs in about one third of the cases filed.17 They have been defendants in about one half of the cases. ${ }^{18}$ Some agencies, not surprisingly, have been both plaintiffs and defendants in different cases, ${ }^{19}$ and in one case there is a state agency on both sides. ${ }^{20}$

Environmental organizations-despite their intense efforts to obtain enactment of the law-have not used the bill frequently. ${ }^{21}$ Apparently, environmental groups in Michigan were not well prepared to use the law when it came into force. Although several of these groups have the benefit of volunteer attorney-members, no Michigan group retains regular litigation counsel. These groups have thus far neither the funds nor the staff to undertake an organized litigation program. ${ }^{22}$ More surprising, perhaps, is the fact that no group has clearly defined a target problem (such as air pollution or highway construction) or a target industry (such as foundries) for which to develop a well-defined legal strategy. This observation is not made critically; it well may be that these organizations, poorly funded and insufficiently aided by technically skilled professionals, are not now prepared to do much beyond responding to problems that are brought to their attention. Perhaps, too, they have been spread thin in valiant efforts to "plug the dike." The problem is exacerbated by the absence of public interest law firms in the state. In light of the preceding observations, it should come as no surprise that suits under the EPA have varied widely in character and have shown no

16. For a discussion of venue, see text accompanying notes 280-97 infra.

17. See Appendices B \& C infra.

18. See id.

19. See id.

20. Water Resources Commn. v. Chippewa County [Water Resources Commission hereinafter WRG (State Highway Department as third party defendant).

21. See Appendices B \& C infra. Only organizations with more than local interests and membership are included in the figures. Many cases involve groups of local residents and ad hoc organizations.

22. For comments on the economics of EPA litigation, see Appendix I infra. 
evidence of a concerted attack on any one phase of environmental problems. ${ }^{23}$

Two encouraging features in the EPA's early history are the expedition with which most cases have been handled ${ }^{24}$ and the willingness of the courts to face up to the environmental issues that truly divide the parties. The thirteen cases already concluded have averaged approximately six months in length. ${ }^{25}$ Of course, most of these cases have been settled out of court, but a number of them were controversies that had previously dragged on for years. Plainly, the EPA is serving as a useful prod to negotiated settlements.

Of the eighteen cases that are still active, only a few have stood for much more than six months without decisive action..$^{26}$ Five have gone to trial on the merits. Most of the others have been quite promptly brought on for hearings on motions for preliminary relief. ${ }^{27}$ One case is being held in abeyance because the issue is not yet ripe for decision. ${ }^{28}$ We are aware of no case in which a defendant is under a restraining order and ready for a trial that is being delayed either by the plaintiffs or by court congestion. ${ }^{29}$

Beyond the willingness-indeed, the expressed eagerness-of the judges to bring pending cases to trial, ${ }^{30}$ there has been an admirable readiness to get to the merits of the cases as soon as possible, rather than to tolerate delaying technical issues interposed by the parties. The courts have, in almost every instance, resisted the temptation to dispose of cases on jurisdictional grounds as a way of avoiding the merits. ${ }^{31}$ When the environmental issues have been presented, the

23. See Appendix E infra.

24. See Appendix G infra. Slower moving cases are WRC v. Chippewa County (delay in getting to trial despite judge's efforts) (see note 78 infra); Lakeland Property Owners Assn. v. Township of Northfield (seven months from trial to issuance of decision); Beaman v. Township of Summit (summary judgment expeditiously granted, but appeal has delayed termination); and Blunt v. Apfel (partial summary judgment granted for defendant; confusion concerning next steps).

25. See Appendix $G$ infra.

26. See id.

27. Preliminary injunctions and restraining orders are discussed in text accompanying notes $151-80$ infra.

28. Leelanau County Bd. of Commrs. v. DNR, Order of Judge Brown (June 14, 1971) (denying motion for summary judgment).

29. Of course, when an EPA suit has been joined with an action for damages in a jury case, there is delay. Bise v. Detroit Edison Co. is the only such case so far.

30. E.g., Ray v. Raynowsky, Transcript of Fearing on Plaintiff's Motion for Temporary Injunction (Nov. 23, 1971) (Ray went to trial on June 19, 1972); WRC v. Chippewa County, (Sept. 1, 1971) (authors' notes from pretrial hearing) (see note 90 infra). In Tanton v. DNR, Judge Brown quickly brought the case on for full trial, rather than hearing extended testimony on preliminary motions.

31. See text accompanying notes 280-97 (venue and jurisdiction), 72-101 (primary jurisdiction) infra. See also Appendix I infra. 
courts have in the vast majority of cases understood them and been able to cope with them intelligently. ${ }^{32}$ To be sure, some of this judicial success is attributable to the limited scale of the cases brought thus far; but perhaps this limited scale is a desirable feature of an evolutionary process.

\section{Factors Affecting Success and Failure}

\section{A. Negotiated Solutions}

Experience thus far suggests that the EPA, at least during its early development, is most likely to be successfully applied ${ }^{33}$ in what may be called the natural small-scale case. ${ }^{34}$ One of the most inter- esting of these cases is Wayne County Health Department $v$. Chrysler Corporation. Chrysler's Huber Avenue foundry in Detroit had installed modern air pollution control equipment that broke down with disconcerting frequency. Efforts over a period of several years by the Wayne County agency to correct the situation had been unavailing: ${ }^{35}$ Chrysler knew that in the event of litigation, a trial judge might respect Chrysler's need to keep the foundry operating lest automobile production lines be forced to close down.

As the Wayne County Health Department (WCHD) viewed its authority prior to the EPA's enactment, it had only two alternatives from which to choose when handling problems like those in Chrysler. It could in some situations seek a judicial order closing the plant, a stern remedy it had never previously invoked; or it could institute a criminal misdemeanor proceeding and recover a $\$ 100$ fine, a tactic it had followed frequently in other cases with predictably unsatisfactory results. ${ }^{36}$ Once the EPA was enacted, however,

\footnotetext{
32. See text accompanying notes 113-50 (trials), 151-80 (preliminary relief) infra.

33. See Appendix F infra for a "won-lost" record.

34. Frequently the scale of a case depends on the lawyer's strategy. West Michigan Env. Action Council v. Betz Foundry, Inc., involving industrial air pollution, might well have been developed on a larger scale. Some cautious preliminary skirmishing by plaintiff, West Michigan Env. Action Council's [hereinafter WMEAC] lawyer led the company-which had not complied with Air Pollution Control Commission regulations for four years-finally to order control equipment. The case might have been used as a vehicle to challenge the Commission's casual enforcement policy and its generous
} use of the variance.

35. Morris, What Pollution Has Cost a Community: A Four-Year Record of a "Clean" Foundry, Detroit Free Press, Nov. 22, 1970, at 1-B, col. 1.

36. Wayne County, Mich., Health Department, Air Pollution Division Regulations art. XIV, \& 14.3 (1972), provides that suit can only be brought with formal approval of the County Health Board after findings of repeated violations. However, this provision was inapplicable in Chrysler's case, since art. VI, \$ 6.6 of the regulations exempted "upset conditions" or "breakdowns." This exemption has recently been eliminated. Adopted Amendments and Revisions to Wayne County, Mich., Health Department, Air Pollution Control Regulation (July 22, 1971). 
the agency's attorney immediately used the new statute to file suits against three large industries. One of these was Chrysler, with which he had unsuccessfully sought negotiated solutions. ${ }^{37}$

It was clear from the first day suits were filed that the agency's attorney intended to use the case as a lever to extract a settlement from Chrysler rather than take the case to trial. He knew that a hard-fought suit by so substantial a defendant could be protracted and expensive; yet he was obviously sensitive to the fact that this prospect could be used to his advantage in negotiating a settlement. If Chrysler appeared to be recalcitrant in front of a busy judge, who was unlikely to be interested in trying a complex air pollution case, the plaintiff would have a powerful weapon with which to force Chrysler to the bargaining table.

But the defendant had a counter weapon. The statute was new and its constitutionality untested. Chrysler's lawyers gave warning that if too much were demanded of them, they would be willing to turn the case into a test litigation.

For several months, negotiations seemed stalemated. Ultimately, the dilemma was resolved in a most interesting way. Several hundred local residents, who had damage suits pending against Chrysler under the common law of nuisance, intervened as plaintiffs in the Chrysler case. $^{38}$ This action broke the stalemate by casting the WCHD as a moderate and by setting determined, private plaintiffs against a determined, industrial defendant. ${ }^{39}$

With their eyes on their own damage cases, the private plaintiffs insisted that Chrysler, as part of the settlement, admit to its wrongdoing. Such an admission was the last thing Chrysler wanted. A search was thus begun for a compromise solution. The demands of the WCHD began to appear eminently reasonable.

Within sixty days, a proposed settlement was presented to the judge. ${ }^{40}$ It provided that Chrysler would carry a ten-day inventory at all times so that if the foundry had to close down for repairs of the pollution control equipment, the automobile production lines would not have to close down as well. In addition, the proposed settlement required Chrysler to closè down its foundry if the equipment malfunctioned and could not be repaired within twenty-four

37. Subsequently, five more cases were filed; see Appendix A infra; note 13 supra. 38 Intervention is permitted by EPA \& 5(1), Mich. CoMP. LAws ANN. § 691.1205(1) (Supp. 1972).

39. Ulimately, the judge dissolved the intervention order; see text accompanying notes 272-79 infra.

40. The consent judgment was entered by Judge Rashid, Oct. 14, 1971. 
hours. Chrysler was also required to make periodic reports to the WCHD in a form of imposed self-surveillance.

The order exemplifies an innovative response to a troublesome conflict between the demands of a major industry for continuity and the demands of the community for air pollution control. Without judicial intervention to prod Chrysler toward compliance, it seems likely that negotiations with the county might have continued interminably. Without private intervenors to give an added push to a well-meaning, but cautious agency attorney, the case might have been permitted to slip onto the inactive docket. The Chrysler case represents a most important success under the EPA in respect of the scope of the order issued.11 It also typifies the expeditious and inexpensive solution that the EPA seems best suited to promote. ${ }^{42}$

Another in this species of case is Trout Unlimited $v$. Milliken. The controversy here arose when a heavy winter snowfall raised cottage-lined Otsego Lake to record levels, threatening the homes with flooding. The Governor declared a state of emergency and requested the United States Corps of Engineers to assist local officials in the designing and funding of a lake drainage project. ${ }^{43} \mathrm{~A}$ proposal was made to dig a channel from the lake to the nearby $\mathrm{Au}$ Sable River, one of the most famous trout streams in Michigan, and to drain the Lake into the Au Sable at up to eighty cubic feet per second.

Fearing erosion, siltation, and eutrophication of the river from the drainage, a coalition of conservation groups, led by Trout Unlimited, threatened a lawsuit if the proposal were approved in its existing form. Local officials responded to the expressed concerns with an agreement to limit maximum drainage to forty cubic feet per second, to install a shutoff valve, and to allow the Natural Resources Commission to monitor the project. On this basis the Commissiondespite a staff report ${ }^{44}$ that delineated the problems inherent in the project-gave its approval, and the Governor authorized the project. ${ }^{45}$

The next day Trout Unlimited, several property owners along the Au Sable, and the Board of County Commissioners-dissatisfied

41. Communications from local residents indicate that the foundry is still causing environmental problems; thus the effectiveness of the consent order remains in question. 42. A consent judgment was also expeditiously obtained in WCHD v. American Cement Corp., Consent Judgment of Judge O'Hair (Dec. 8, 1971). The other WCHD cases are still in negotiation.

43. Detroit Free Press, June 18, 1971, at 3-A, col. 2.

44. DNR Statement on the Environmental Consequences of the Otsego Lake De. Watering Project into the North Branch Au Sable River, June 14, 1971.

45. Detroit Free Press, June 18, 1971, at 4-A, col. 6. 
with the agreement approved by the Commission-filed suit under the EPA. The court granted a temporary restraining order, and the following day the defendant county officials sat down to bargain in earnest with the plaintiffs. The plaintiffs knew exactly what concessions they would require: a reduction in the maximum rate of flow, an explicit monitoring agreement that spelled out the conditions under which the flow would be reduced or stopped, and control over the shutoff valves in the hands of the Department of Natural Resources (DNR) rather than under the control of the County Road Commission's engineers.

Each of these demands, as the intensive bargaining sessions demonstrated, was consistent with the cottage owners' minimum needs. Under the shadow of an imminent courtroom hearing, each was accepted; a detailed order formalizing the results of the bargaining session was then signed by the judge. ${ }^{46}$

Trout Unlimited was a classic version of successful citizeninitiated litigation in which plaintiffs who know what they wantbut who also know that what they need is somewhat less-are prepared to negotiate with their adversaries. In such circumstances, a court is used most efficiently, for its potential power gives leverage to the plaintiffs and suggests to both parties that they ought to hone their demands down to the point that would be sustainable if the case went to trial. This manner of using the courts to change the balance of power, while leaving the court itself in the background, has been one of the most successful tactics for plaintiffs under the EPA. It suggests that in a number of environmental controversies a central problem has been a power imbalance among the interested parties-a concern that was central during the legislative consideration of the bill..$^{47}$

Trout Unlimited suggests also that the EPA works most efficiently when used as a lever to press regulatory agencies into seeking new solutions to environmental problems. Although the Natural Resources Commission had done a study on the Otsego Lake drainage, it had not fully considered all the alternatives; and the negotiations carried on under the threat of a trial pushed into the foreground other possible solutions, including-as it turned out-one sufficient to satisfy all the participants.

46. Trout Unlimited v. Milliken, Interlocutory Consent Order of Judge Hughes (Aug. 9, 1971).

47. Testimony of Joseph L. Sax on H.B. 3055, before the Committee on Conservation and Recreation, Michigan House of Representatives, Jan. 21, 1970, excerpts reprinted in 14 Mich. Law Quad. Notes 27 (1970). 
Finally, the case demonstrates the usefulness of a law like the EPA in "liberating" regulatory agencies from political pressure. Given the highly political content of the controversy, which included meetings with the Governor, it would have been difficult without the EPA for the Commission to hold out for important, but not highly visible, constraints-such as a detailed procedure for monitoring rather than a simple, more general agreement, and use of its own staff rather than that of the Road Commission to control the shutoff devices. Yet, when forced to anticipate what might have to be proved in a courtroom-in a suit instituted by a private citizen under the EPA - the Natural Resources Commission was able to respond more professionally and less politically. As the assistant director of the Commission described the outcome of Trout Unlimited in responding to an inquiry about the case: "The settlement definitely strengthens our hand with respect to controlling any possible adverse effects .... I am certain that without the order, we would not have [been able] to completely control the situation." 48

\section{B. Politically Volatile Controversies}

Trout Unlimited was only one of several cases in which the EPA has been a useful device for relieving pressures in highly charged political controversies. These cases emphasize the special importance of permitting private citizens to take legal initiatives.

Michigan United Conservation Clubs v. Anthony ${ }^{40}$ was filed under the EPA to require Indians to comply with State fishing regulations. The controversy, arising out of a concern with the depletion of Great Lakes fisheries, reached an interim crisis in 1971 when the Michigan supreme court decided People $v$. Jondreau. ${ }^{50}$ The defendant in that case, a Chippewa Indian, was prosecuted for violating the State fishing laws; the court concluded that the law could not be applied to him because a treaty between his tribe and the United States guaranteed him certain rights to hunt "without limitation, restriction or burden." 51

The Attorney General orally advised the DNR that the decision applied to all Indians, and the DNR, as a result, suspended enforcement of game and fishing laws against all Indians. ${ }^{52}$ Shortly thereafter

48. Letter from A. Gene Gazley, Assistant Director, DNR, to Roger Conner, Aug. 2,1971 , on file with author.

49. See text accompanying notes 175-77, 290-97 infra.

50. 384 Mich. 539, 185 N.W.2d 375 (1971).

51. 384 Mich, at 552, 185 N.W.2d at 381.

52. Evening News (Sault Ste. Marie), Sept. 1, 1971, at 1, col. 3. The DNR con- 
Donald Anthony, an Indian, began fishing with large, mesh-nylon gill nets. Given the long struggle to control the use of gill nets and existing tension between whites and Indians, the ensuing conflict was not surprising. Reports began to circulate that Indians could wipe out sport fisheries in Grand and Little Traverse Bays in a year with their gill nets, ${ }^{53}$ and rumors that sports fishermen were threatening to "[d]estroy the Indians' nets, sink their boats and, even, shoot the netters," 64 ran rampant.

Finally, the Governor, in an attempt to bring the opposing factions together, personally intervened by calling a meeting. The tone of the meeting was bitter. "We will make up our own peace force and do what we have to do to protect ourselves and our equipment," one Indian warned darkly. ${ }^{55} \mathrm{~A}$ task force was appointed by the Governor, but-beyond recommending that the DNR work with Indian leaders to seek a solution-it was unable to find a compromise acceptable to all parties. In a sense, government was paralyzed; the buck had been passed from the DNR to the Attorney General, to the Governor, to a task force, and back to the DNR.

With tensions continuing to rise and no solution in sight, Michigan United Conservation Clubs (MUCC) filed suit under the EPA to enjoin all Indians not specifically covered by Jondreau from violating state fishing regulations. The suit relieved the pressures mounting from newspaper attacks and focused attention on legal issues that would have to be resolved in the courtroom. Following an extensive hearing, in August 1971 the court issued a preliminary injunction requiring compliance with fishing regulations..$^{56}$ The decision, though not warmly received by the Indians, at least provided an opportunity for passions to cool. By September the DNR had announced that, while it would begin enforcing the fishing laws against the Indians, it would nevertheless issue some free "compassionate" commercial licenses to Indians for areas in which additional netting "[w]ill not place undue pressure on Great Lakes Fish stocks."כ̄7

tinued its suspension of enforcement of the law against Indians even after the supreme court in denying a petition for rehearing on Aug. 30, 1971, clarified its Jondreau opinion indicating its narrow application to particular bands of Indians. See Evening News (Sault Ste. Marie), Sept. 1, 1971, at 8, col. 1. This is indicative of the politically heated nature of the controversy.

53. North Woods Call, June 30, 1971, at 6, col. 1 .

54. Id.

55. Pontiac Press, July 8, 1971, at C-3, col. 3.

56. MUCC v. Anthony. The hearing and order are discussed at text accompanying notes 175-77 infra.

57. Michigan Daily, Sept. 22, 1971, at 3, col. 5; State Journal (Lansing), Jan. 26, 1972, at B-4, col. 1; North Woods Call, Feb. 9, 1972, at 5, col. 1. 
In Payant v. Department of Natural Resources, 88 the EPA was used effectively to moderate another highly controversial local issue - the hunting of antlerless deer. The DNR's policy of allowing antlerless-deer-hunting was strongly opposed by public opinion in Dickinson County, where suit was brought to enjoin the Department's program shortly before the beginning of the 1971 hunting season.

In 1970 , the county commissioners had held a referendum in which the county's citizens voted by a three-to-one margin to support a three-year moratorium on the hunting of antlerless deer. ${ }^{50}$ This referendum placed the DNR in an unenviable position. It was enforcing a program it believed to be scientifically sound, but the program was in perpetual jeopardy because of political pressures generated by its unpopularity. At the same time, the DNR feared the outcome of a lawsuit in hostile territory. When suit was finally instituted-by the state legislator who represented Dickinson County - the Department's worst fears seemed to be coming true. It was reported that "two of three judges assigned to the case were known to be lacking in sympathy for the deer management program," one DNR staff biologist was quoted as saying that "an Upper Peninsula judge might give more credence to 'some old hunter's opinion than to ours. ... " 61 The suit was prominently played up in local newspapers, the court galleries were filled during the trial, and pickets paraded outside the courtroom. ${ }^{22}$ One of the judges even received anonymous threatening phone calls. ${ }^{63}$ The case promptly went to trial, and soon thereafter the court issued an opinion completely vindicating the defendant DNR.

Perhaps the final comment on this subject should be left to A. Gene Gazley, Assistant Director of the DNR:

With respect to the Payant case, it is certainly true that the Department is better off after proving its case than it would have been

58. See text accompanying notes 113-23, 198-99, 237-38 infra.

59. Payant v. DNR, Complaint 6.

60. Letter from A. Gene Gazley, Assistant Director, DNR, to Roger Conner, Dec. 14, 1971, on file with author [hereinafter Gazley Letter]. Three judges were appointed to hear the case under Mrch. CT. (GEN.) R. 9253 (1969). It is interesting to note the availability of this rule in controversial local cases. It eases the responsibility of any single judge without requiring abdication of judicial responsibility.

Three judges were also appointed in Muskegon County v. Environmental Protection Org., another highly controversial case.

61. North Woods Call, July 21, 1971, at 1, col. 4.

62. Interview with Judge Brown, Jan. 29, 1972, on file with authors.

63. Id. 
had the case never occurred ... the unanimous opinion that resulted from the trial was a ringing endorsement of our program.

It is reasonable to expect that an opinion of this sort is bound to impress some of the people that were either skeptical or against our management program ... the fact that the complaint was dismissed in the homeland of the adversary was reassuring and a definite credit to our management program. It should make it easier to win some of the future battles that are certain to occur in the Legislature and on the home front over this very controversial topic of deer management. ${ }^{64}$

\section{G. The Ambitious-Case Problem}

Having discussed some of the prototype small-scale suits under the Act, we turn to a case that was intended to be big and important, Roberts $v$. Michigan. ${ }^{\circ 5}$

The plaintiff in Roberts was an inventor of equipment for the control of automobile exhaust emissions. ${ }^{60}$ Concerned that the state had been lax in controlling automobile air pollution, Roberts could have brought suit against the Michigan Air Pollution Commission and challenged their program of monitoring, regulating, and enforcing automobile exhaust. Instead, he chose a much more radical course, suing the State, the Secretary of State, and the Director of the State Department of Highways. Roberts alleged first that the Secretary of State violated the EPA by granting licenses to operate motor vehicles that polluted the air and by failing to adopt standards and regulations to control motor-vehicle-caused pollution. The plaintiff sought to have adequate standards imposed by court order and to have the licensing and operating of motor vehicles enjoined until such standards were established and enforced.

Roberts also alleged that the State Highway Department was violating the EPA by allocating tax money for construction and maintenance of highways in the state, the use of which caused air pollution. Plaintiff sought the establishment of regulations to govern pollution arising from the use of the highways, and also asked that highway construction be enjoined unless and until adequate safeguards dealing with this problem were adopted.

64. Gazley Letter, supra note 60 . The issue is not yet dead; some still oppose antlexless-deer-hunting. Ann Aurbor News, March 19, 1972, at 34, col. 1.

65. See text accompanying notes 225-30, 239-41, 256-60 infra for further discussion of Roberts.

66. So far as we know, Alvin E. Bertrand, Inc. v. City of Detroit is the only other EPA case in which the plaintiff was a business competitor. Bertrand has a disposal business, and the suit involved an allegedly polluting city incinerator. 
While the underlying issues in Roberts-the adequacy of Michigan's automobile air pollution regulations and their enforcementwere hardly shocking, it was inevitable that the relief sought would impair whatever value such a case might have had in calling attention to the automobile exhaust question. Newspaper reports on the case were predictable: A typical one was headed "Pollution Foe Bids Roadbuilding Halt," 67 but a more extreme article contained the heading, "Inventor Sues to Halt Pollution by Eliminating Cars,"08 and began with the sentence: "Michigan will have to go back to the horse and buggy for transportation if Charles G. Roberts has his way."

The Roberts case cannot be put aside simply as a valiant, if misguided, early effort to use the EPA to its fullest extent in dealing with a serious environmental problem. Indeed, Roberts demonstrates one of the most troublesome issues arising out of the enactment of a law designed to benefit what may loosely be called a movement or a cause-the inability of any leadership to control the kinds of cases brought or the manner in which they are litigated. Ironically, the real problem is quite the opposite of that feared by those who opposed the EPA's enactment; these critics had been worried that overzealous environmentalists might concertedly organize to tie the hands of regulatory agencies or to attack in overwhelming fashion certain agricultural or business interests. ${ }^{68}$ Instead, the danger is that inadequately planned litigation will produce damaging legal precedents and will generally impair the reputation of plaintiffs who use the statute.

Roberts also potentially opened one of the most complex questions in environmental law: Upon which regulatory agencies does the task of environmental management rest? ${ }^{70}$ The EPA, properly in our judgment, is drafted so that the issue can be raised. The disturbing thing about Roberts is that the plaintiff seemingly stumbled into this question, posing a dilemma for the judge. If the question of what parties were proper defendants was to be resolved, difficult legal issues, which none of the lawyers were prepared to confront,

67. Grand Rapids Press, Oct. 28, 1970, at 8-C, col. 4.

68. Detroit News, Oct. 29, 1970, at 17-A, col. 1 .

69. See Mining Journal, Jan. 22, 1970; Michigan State Chamber of Commerce State Legislation Report, Jan. 15, 1970 at 2; Michigan Riparian, Sum. 1970, at 4, col. 1.

70. See, e.g., Zabel v. Tabb, 430 F.2d 199 (5th Cir. 1970) (duty of Corps of Engineers to consider effects other than navigational); New Hampshire v. AEC, 406 F.2d 170 (lst Cir.), cert. denied, 395 U.S. 962 (1969); Calvert Cliffs Coordinating Comm. v. AEC, 419 F.2d 1109 (D.C. Cir. 1971) (obligations of the AEC other than protection against radiation hazards). 
had to be untangled. Predictably, the judge responded by lashing out at the statute itself, finding it in part unconstitutional as applied to the facts of the case.

Fortunately, the opinion on unconstitutionality in Roberts has not been treated as a significant precedent in other EPA litigation. Roberts has been appealed, and it appears that the plaintiff-appellant will substantially tone down his case in an effort to win a reversal of the trial court's order of dismissal. ${ }^{71}$

\section{INTERPLAy BeTWEen THE EPA AND THE Administrative Process}

\section{A. Primary Jurisdiction}

The EPA permits lawsuits to be instituted on matters cognizable before administrative agencies even though administrative action has not been completed. ${ }^{22}$ Our single-track tradition in law enforcement, which is manifested in the primary jurisdiction doctrine, is so well established that considerable concern was expressed about the feasibility of an enforcement system in which different legal routes for dealing with a given environmental problem would be simultaneously available.

The theoretical potential for conflict is obvious, but the legislature was persuaded that in two respects the risk was worth taking. Because regulatory agencies are not always diligent, it was hoped that private plaintiffs, using the potential power of a court order, could, when necessary, prod the agencies to a more energetic fulfillment of their responsibilities. In addition, it was thought that the range of environmental problems is sufficiently great that a more flexible arsenal of enforcement techniques would be helpful. Thus, while

71. Roberts v, State appeal docket, No. 13640, Mich. Ct. App. In Marble Chain of Lakes v. Water Resources Commn., the only other "big" case brought thus far under the EPA, the WRC was challenged for allowing discharges of water that are of lesser quality than the receiving water. In short, the case questioned the legitimacy of using water for waste assimilation. The complaint was filed in December 1970, and the case was voluntarily dismissed by the plaintiff on May 10, 1972. Certainly, the plaintiff would have faced great diffculty in obtaining the extraordinary technical evidence that would have been necessary in such a far-reaching case. In essence, he sought to obtain by judicial mandate what other environmentalists hope to accomplish through the pending federal Water Pollution Control bill: a no-discharge rule for Michigan streams and lakes. See S. 2770 \& H.R. 11896 (92d Cong., 2d Sess.) (1972). A weaker version of H.R. 11896 was passed by the House March 29, 1972. N.X. Times, March 30, 1972, at 18, col. 4.

The federal bill is itself hotly controverted as an unrealistic aspiration-even for ten years hence when the bill takes effect and even with a multibillion dollar authorization for treatment works construction. The bills are discussed at length in Barfield, The National Journal, Jan. 15, 1972, at 84, Jan. 22, 1972, at 136.

72. EPA \& 4(2), Mich. CoMp. LAws ANN. \& 691.1204(2) (Supp. 1972). 
in some cases it is no doubt more appropriate to follow the elaborate process of notice-hearing-final order that many regulatory statutes incorporate, ${ }^{73}$ there are also cases in which immediate resort to the courts for injunctive relief might be more serviceable.

Because the most desirable enforcement technique could not be easily identified and reduced to a statutory formula, the EPA left considerable flexibility to a judge before whom suit was brought to decide whether to carry the case directly through the judicial process or to return it, in whole or in part, for administrative action. The statute provides in section $4(2)$ that whenever administrative pro. ceedings are available to determine the legality of the challenged conduct and suit is brought under the EPA, "the court may remit the parties to such proceedings," 74 and in doing so may grant interim equitable relief if necessary to protect the interests governed by the Act.

While in theory the alternative-route approach should solve the problem of the need for judicial maneuverability, whether such flexibility would in practice be achieved was one question that could only be answered after the EPA had been in effect for some time. Though several Michigan statutes incorporate similar schemes, 76 vigorous application of the primary jurisdiction doctrine by the Michigan courts ${ }^{76}$ has made administrative proceedings, for the most part, the sole legal tool available to complainants.

In Water Resources Commission v. Chippewa County, the EPA's alternative-route strategy was soon put to the test in a rather unexpected setting. The Water Resources Commission (WRC) brought suit against Chippewa County and the Board of County Road Commissioners alleging a violation of the EPA. ${ }^{77}$ The conduct challenged by the Commission was the storage of salt for winter road-clearing on the Road Commission's land. Allegedly, the salt seeped into the

73. See, e.g., Air Pollution Act § 7-14, Micr. CoMr. LAws ANN. § 336.18-.24 (1967); Water Resources Commission Act § 7-13, Mich. Comp. LAws ANn. \& 323.7-.13 (1967), as amended, (Supp. 1972).

74. Mich. CoMp. LAws ANn. \& 691.1204 (Supp. 1972) (emphasis added).

75. For instance, the Water Resources Commission Act \& 6(c), Mrcr. Comp. LAws ANN. \& 323.6 (1967), as amended, (Supp. 1972), allows the Attorney General to abate water pollution as a public nuisance while section 12-12(a) of the Act, MicH. CoMP. LAws ANN. \& 323.12-.12(a) (1967), explicitly makes the Act ancillary and supplementary to the existing law governing water pollution.

76. White Lake Improvement Assn. v. City of Whitehall, 22 Mich. App. 262, 279-80, 177 N.W.2d 473, 481 (1970).

77. The suit also alleged that the conduct constituted a continuing trespass upon the underground waters of the state and a public nuisance under $\S 6$ of the Water Resources Commission Act, Mrar. Comp. LAws ANN. \& 323.6 (Supp. 1972), abatable pursuant to the Revised Judicature Act, $\S 2940$, Micr. CoMp. LAws ANN. $\$ 600.2940$ (1968). 
ground water from which nearby residents took their domestic water supply by wells.

Under the facts as asserted by the plaintiff WRC, the case was impressive. The concentration of chlorides in the nearby wells had been within the limits established by the United States Public Health Service prior to the defendant's act, but shortly thereafter it was found to be substantially in excess. As a result, the residents had to transport water from a nearby city in five- and ten-gallon cans twice a week.

The salt stockpile had been removed by the time the case began, but one problem still remained. There was no feasible way in which to decontaminate the already saline water. The suit, therefore, must have been brought to obtain at least one of two practical solutions for the nearby residents: the acceptance of financial responsibility by the Road Commissioners for an interim supply of water, ${ }^{78}$ or an arrangement to tap the residents on to the nearest municipal water supply.

One is naturally curious why the WRG departed from its customary administrative procedures and went directly into court under the EPA, for there was no evidence that the WRC was searching for a case in which it could test the EPA. A likely answer is suggested by examining the background of the controversy. Following complaints by local residents, the WRG undertook an investigation that demonstrated to its satisfaction that there was contamination caused by the salt storage. ${ }^{79}$ At that time the WRG called in the Board of Road Commissioners to try to work out a solution. ${ }^{80}$ The Road Commissioners, however, refused to take any corrective action,

78. The complaint did not expressly seek damages. It sought an injunction against further storage and "to the extent that abatement ... is necessary ... [a] mandatory order directing said Defendants to pump, or otherwise remove, said contaminants from the underground waters." WRC v. Chippewa County, Complaint at 6. This relief was probably designed to force the defendant to accept financial responsibility for the costs of an alternate supply, for there is no accepted way to decontaminate the ground water. As to a claim that any damages would have to be sought in the court of claims, the court held that the Court of Claims Act did not oust a circuit court of jurisdiction it otherwise had under a statute. WRC v. Chippewa County, Opinion and Decision of Judge Hood (May 27, 1971) (denying defendant's motion for summary judgment or accelerated judgment). The following comment was recently made concerning this litigation in a letter from Raymond $F$. Clevenger, attorney for defendant, to Joseph L. Sax, May 31, 1972, on file with author: "[T] his case was scheduled for trial in May [1972]. But it wasn't tried, and I still doubt that it will be-or should be . . . . At the 'final' pre-trial, a greater consensus was found that the entire matter should be resolved by building a water system. The cost . . is now estimated at $\$ 220,000$. In addition, the property owners want approximately $\$ 40,000$. We're trying to find the money."

79. Affidavit of Ralph Purdy, Executive Secretary WRC, Feb. 10, 1971, at 2.

80. Id. at 1-2. 
arguing that they were merely agents for the State Highway Department. ${ }^{81}$

Chippewa County thus presented none of the usual problems for which the WRC's ordinary administrative approach was especially useful. The WRC was satisfied that the facts had been established; the usual problems of financing or scheduling that arise in an ordinary industrial- or municipal-pollution case were not present. The case called for an imaginative solution to the question of who should bear the costs for the harm done. The local residents were, understandably, seeking as expeditious a solution as possible; and the sticking point seemed to be a purely legal question: upon whom did responsibility lie, the county or the State Highway Department?

Ghippewa County must have seemed a particularly appropriate case for the invocation of the new direct-action EPA. The WRG referred the case to the Attorney General, and suit was filed in February 1971. Predictably, the defendant County Road Commissioners, seeking indemnity for any liability imposed upon them, joined the State Highway Department as a third-party defendant. ${ }^{82}$

At this point the Board of County Road Commissioners sought summary judgment on the ground that the plaintiff WRG had not complied with its own regulatory statute, which, the motion asserted, "requires that said Water Resources Commission give notice of any violation of said act and that its findings be made after proper Hearing, with a resultant Order . . . . No Hearing was had and no Order has been made by Plaintiff to this Defendant."83

Judge Hood, noting two often forgotten provisions of the Water Resources Act, responded that there is no statutory requirement and no state policy requiring all water pollution controversies to follow the WRC's routine administrative procedure:

The Water Resources Act contemplates and permits alternate procedures where a violation of the act is claimed. One procedure

81. Id. at 3.

82. This development created the unusual situation in which the Attorney General was counsel for both plaintiff and defendant. Apparently, no serious problems developed from this extraordinary arrangement; separate lawyers were assigned to each client and each seems to be representing his client with appropriate vigor. Of course, the Highway Department attorney is not invoking constitutional objections to the EPA, but that is consistent with a policy of the Attorney General's office in all cases under the EPA. During the legislative consideration of the EPA, the Attorney General sup. ported the bill's enactment; and he has also testified in favor of similar federal legisla. tion. Hearings on H.R. 49 \& 5074, Before the Subcomm. on Fisheries and Wildlife of the House Comm. on Merchant Marine and Fisheries, 92d Cong., Ist Sess. at 7 (1971).

83. Motion of Defendant for Summary or Accelerated Judgment, April 28, 1971, WRC v. Chippewa County. Reference is to Water Resources Commission Act \& 7, Mich. Comp. Laws AnN. § 323.7 (Supp. 1972). 
involves notices, hearings, findings and orders by the Water Resources Commission itself, as set forth in Section 7 of the Act; but the alternate procedure is direct court action as set forth in Sections 3 and 6.c of the Act. If direct court action is used, notices, hearings, findings or determinations by the Commission are neither necessary or pertinent to the court action; and it is immaterial that the Water Resources Commission may have had some proceedings without proper notice or proper hearing. ${ }^{84}$

Turning then to the court-made doctrine of primary jurisdiction, Judge Hood noted the view of the court of appeals ${ }^{85}$ that administrative agencies, such as the WRG, "normally should not be bypassed." ${ }^{86}$ However, he continued:

[As] the Court of Appeals indicated, there are no hard and fast rules for application of the "primary jurisdiction" doctrine; and whether to apply it to a particular case depends upon many circumstances. In the White Lake case the Water Resources Commission had taken jurisdiction and acted after a dismissal order had been entered in the Circuit Court suit ... to take the matter out of the hands of the Water Resources Commission and return it to the Circuit Court would require the Circuit Court to duplicate the efforts of the Water Resources Commission. It was noted that considerable sums may already have been expended on engineering and other like work in connection with the implementation of the existing Water Resources Commission orders. . . I In our case there has been no agreement, decision or order by the Water Resources Commission. ... The interest of justice will not be served by the Court passing the problem back to the Water Resources Commission at this time. ${ }^{87}$

What Judge Hood did not say, although it may perhaps be read between the lines of his opinion, is that it would push the primary jurisdiction doctrine- a doctrine that cautions against excessive judicial intervention in the administrative process-to a ludicrous extreme if it were enforced against the very administrative agency that has itself come into court as a plaintiff seeking judicial aid and has

84. Chippewa County Opinion, supra note 78, at 3. Water Resources Commission Act § 3, Mrch. CoMr. LAws ANN. § 323.3 (Supp. 1972) provides: "The Commission shall be authorized to bring any appropriate action ... either at law or in chancery as may be necessary to carry out the provisions of this act, and to enforce any and all laws relating to the pollution of the waters of this state." Section 6(c) of the Act, MIct. CoMr. Laws ANN. \& 323.6 (Supp. 1972) provides: "Any violation of any provision of $\$ 6$ shall be prima facie evidence of the existence of a public nuisance and in addition to the remedies provided for in this act may be abated according to law in an action brought by the attorney general in a court of competent jurisdiction."

85. White Lake Improvement Assn. v. City of Whitehall, 22 Mich. App. 262, 279, 177 N.W.2d 473, 481 (1970).

86. Chippewa County Opinion, supra note 78, at 4.

87. Id. 
asserted that "further administrative proceedings would not alleviate or correct the [problem]." 88

Finally, the judge made clear that whatever rigors might have been thought to characterize the law of primary jurisdiction previously, the EPA had added a significant statutory dimension to the question:

This Court notes that under the Environmental Protection Act of 1970 the court under some circumstances, while retaining jurisdiction, may remit the parties to proceedings before administrative agencies. It may be that during the course of these proceedings such remission will appear advisable and may be ordered. At this stage, however, the Court feels that the interest of justice will be more swiftly served by this case proceeding as rapidly as possible to issue before this Court. After the case is at issue, determination can be made as to the procedural steps then to be taken. Perhaps it will then appear expedient for this Court to decide certain factual issues which might dispose of the case; or which could furnish the foundation for remitting the parties to the Water Resources Commission for determination of the measures to be taken to eliminate contamination. ${ }^{89}$

Beyond its usefulness as a precedent on the relationship between the EPA and the doctrine of primary jurisdiction, the salt pollution case is important because it suggests that the EPA may be playing a significant role in liberating both the administrative agencies and the courts from their traditional approach to disputes. To be sure, the WRG might have brought a suit similar to this one as a conventional public nuisance suit; but that power has long existed and has been used very rarely in situations subject to the routine hearingorder practice. Similarly, judges might have been able to break away from traditional notions of primary jurisdiction, but in the absence of the new EPA, such a move might have seemed unduly innovative.

There is, naturally, a large measure of speculation in these analyses of the EPA's impact, but it is important to consider that the legal system, like all institutional structures, is highly inertial, and that a strong statutory invitation, such as that provided by the EPA, may be most significant in its power to suggest new ways of doing business. Plainly, the EPA cannot press an agency or a court to take initiatives that it feels are imprudent. But if, as seems to be the case, the WRC felt frustrated with the recalcitrance of the Board of Road

88. Purdy Affadavit, supra note 79, at 3-4.

89. Chippewa County Opinion, supra note 78, at 5-6. 
Commissioners and uneasy about the efficacy of its usual procedures; and if a judge feels that the case is an important one, ${ }^{90}$ and one that he is likely to be able to handle, the EPA can work as an effective catalyst.

The primary jurisdiction problem arose in a more conventional setting in Lakeland Property Owners Association v. Township of Northfield. The defendant township was piping its treated sewage some miles and discharging it into bodies of water situated near the plaintiffs. The plaintiffs, claiming that the waters constituted pollution, challenged a proposed enlargement of the treatment plant and sought an alternative place of discharge. Among the plaintiffs' allegations was the complaint that the public needed effuent standards more restrictive than those established by a WRC order ${ }^{91}$ previously issued against the defendant township.

The WRC-having issued the order just mentioned-was apparently finished with the case except for possible monitoring of compliance. When suit was filed under the EPA, however, the defendant sought a remand to the WRG under the doctrine of primary jurisdiction..$^{22}$ The plaintiff replied that among its claims were issues not cognizable by the Commission, such as trespass and nuisance; andmost important-that it was challenging "the reasonableness of orders of the Water Resources Commission, and it would thus be improper to remit this action to the Commission and ask it to pass on the reasonableness of its own orders." 93

Certainly, the court was not being asked to interfere with any ongoing proceeding before the $\mathrm{WRG}^{94}$ nor was it obvious that there

90. The judge opened the pretrial Sept. 1, 1971, with the following comments:

How close is the matter to being ready for trial? ... This is an important case.

The situation should be resolved as soon as possible. If there is responsibility in

one of the defendants or not, it should be known at the earliest possible time. ...

Is there anything I can do to push this along? ... There is no point in playing

games with witnesses and discovery.

Authors' notes taken at hearing.

91. Final Order of Determination, Proceedings Against the Township of Northfield for Abatement of Pollution of the Horseshoe Drain and the Huron River, No. 1316 (August 20, 1969).

92. The defendant relied heavily upon White Lake Improvement Assn. v. City of Whitehall, 22 Mich. App. 262, 177 N.W.2d 473 (1970).

93. Response and Memorandum of Plaintiff in Opposition to Motion for Reference to WRC at 2, Jan. 7, 1971, Lakeland Property Owners Assn. v. Township of Northfield.

94. See text accompanying note 90 supra. See also note 84 supra. See discussion of Lakeland in text accompanying notes 146-50, 171, 261-66 infra. A variant situation arose in WMEAC v. Betz Foundry, Inc. See note 34 supra. The foundry had failed to comply with the Air Pollution Control Commission's regulations for almost four years. The Commission began to take an active interest in the case just as the lawsuit was filed and, shortly thereafter, negotiated an agreement with the foundry for the installation of control equipment. To protect itself, the plaintiff, after filing suit, 
was any further contribution of technical expertise that the Commission was prepared to provide for the suit. Accordingly, the judge held that

there were matters before this court not triable by the ... Water Resources Commission or any administrative tribunal. It was the further opinion of this court that the court would retain jurisdiction of the suit now pending in those areas where it does have primary jurisdiction with specific reference to the setting of effluent levels currently being discharged by defendant. ... The court was further of the opinion that the convenient administration of justice would necessitate retaining jurisdiction..$^{85}$

He then denied the motion for reference to the WRC, adding "this order shall not be construed to deprive ... the Water Resources Commission of any jurisdiction they may have under the statutes ... and such administrative bodies may pursue any proceedings they are currently engaged in with respect to Northfield Township's sewage treatment facility. ...."98

With this decision the judge maintained a posture of great flexibility. He permitted a significant controversy to go forward by reject-

sought to intervene in the Commission proceedings under \& 5(1) of the EPA, MIcr. COMP. LAws ANN. \& 691.1205(1) (Supp. 1972), while the court maintained jurisdiction. The agency denied the application for intervention, and the court refused to requirc the Commission to permit the plaintiffs to intervene before the agency. The court stated that "the plaintiffs have no inherent right to be joined [in the Commission's proceedings against Betz] without the consent of the Commission." WMEAC v. Betz Foundry, Inc., Opinion of Judge Hoffus at 4 (Dec. 10, 1971). The reason given for denying intervention was that "to permit each and every interested person . . . to be made a party to the administrative proceedings . . . could so deter the Commission that it could fail by reason thereof to carry out its responsibilities." Id. The court observed that the plaintiffs could get review of Commission action through the review procedures provided by the Air Pollution Act and the Administrative Procedures Act. In short, the judge simply ignored the plaintiff's right to sue under the EPA, and he thus failed to take advantage of the opportunity to integrate the pending court case with the pending administrative proceeding involving the same parties. This decision has been appealed. WMEAC v. Betz Foundry, Inc., appeal docketed No. 143355, Mich. Ct. App., Grand Rapids.

95. Lakeland Property Owners Assn. v. Township of Northfield, Decision and Order of Judge Mahinske at 1-2 (Jan. 26, 1971) (denying motion for reference to WRG). See also Lakeland Decision of Judge Mahinske at 20 (Feb. 29, 1972):

... this Court is not unmindful of the law set out in White Lake Improvement Association v. Whitehall. . . . This Court is of the opinion that White Lake, and the rules set out therein, is no longer controlling in that [the EPA] specifically \& 2 thereof, denies the Water Resources Commission primary jurisdiction in matters such as are now before the Court. The primary jurisdiction doctrine was the controlling factor employed by the Court of Appeals in its disposition of White Lake but such doctrine was coupled with considerations of the lack of advance judicial proceedings when such doctrine was asserted and the fairness or unfairness of remitting plaintiff therein to another proceeding, and further, such doctrine was employed in the absence of the language now found in [the EPA]. It should be understood that this Court does not disagree with the rationale for nor the necessity of the primary jurisdiction doctrine but merely points out that the same is not absolutely controlling herein.

96. Lakeland Decision and Order of Jan. 26, 1971, supra note 95, at 2. 
ing defendant's argument that an appeal under the Water Resources Act was the only way the plaintiffs could challenge the standards in the Commission's order. And he retained the opportunity to pass on those issues raised by the plaintiff that were not cognizable by the Commission without depriving the WRG of any contribution it might wish to make by taking independent action or by participating in the litigation.

This judicial ploy was successful. Having lost the primary jurisdiction motion, the defendant went back to the WRG and obtained a revised, and more detailed, order of determination that set specific effluent standards for a number of substances. ${ }^{97}$ The new order, according to a Commission expert, contained "some of the strictest standards which have ever been applied to any municipal sewage treatment plant." ${ }^{88}$ Thus the suit prodded the WRG to far-reaching action of a kind it had previously failed to take.

As subsequent events demonstrated, the WRC did not go far enough to satisfy the court. Following a full trial, Judge Mahinske issued a decision in favor of the plaintiffs, holding, inter alia, that compliance even with the new standards, was not sufficient in all respects to prevent unlawful pollution. ${ }^{99}$ Judge Mahinske, when later interviewed by the press regarding his decision, noted that the standards he imposed in Lakeland "are a compromise between the zero-pollutant levels one expert witness ... called for in testimonythat is, pure drinking water ... and the WRG original standards."100 Thus far, Lakeland is the only EPA case in which detailed quantitative standards of an administrative agency have been revised. ${ }^{101}$

\section{B. Augmentation of the Enforcement Process}

Kelley v. Tannehill o DeYoung, Inc., involving the Northern Reduction Company, a rendering plant that manufactures pet food,

97. Amended Final Order of Determination, Proceedings Against the Township of Northfield for Abatement of Pollution of the Horseshoe Drain and the Furon River, No. 1478 (March 18, 1971). trial).

98. Testimony of Mr. F.B. Frost, at trial, July 22, 1971 (authors' notes taken at

99. Lakeland Decision of Feb. 29, 1972, supra note 95.

100. State Journal (Lansing), March 6, 1972, at B-5, col. 5-6. The judge said that he relied on the WRC Water Quality Standards for total body contact waters that were devised for Northfield.

101. The detailed deer hunting regulations of the DNR were vindicated in Payant v. DNR (discussed in text accompanying notes $113-23$ infra) and more general agency authorizations have been put in question in a number of other cases. E.g., Blunt v. Apfel (WRC new use permit; Dept. of Public Health septic tank approval); Ray v. Raynowsky and Gang of Lakes Env. Org. v. Gee (Dept. of Agriculture orders); Tanton v. DNR (dam permit). 
dealt with what may be the most notorious case of industrial recalcitrance in recent Michigan environmental history. The history of this case dramatically demonstrates what can happen when an industry committed to delay faces an agency with almost limitless patience operating under a statute that requires it to use "conference, conciliation and persuasion . . . to the fullest extent possible." 102

After a Health Department site visit in 1963, which was prompted by local complaints of nauseating odors coming from the plant, regulatory officials wrote, pleaded with, and issued orders to the company, hoping to induce some cooperation from Northern in eliminating the odors. Prior to 1968, Northern had undertaken some housekeeping reforms to eliminate the odor, presumably to pacify the Health Department, but when approached by the Air Pollution Control Commission in 1968, Northern claimed that the odor, which was caused by its waste treatment lagoon, would soon disappear. When complaints continued to be made to the Commission-many of these from a nearby factory manager who claimed that his employees were made sick by the smell-the Commission threatened further action. Northern responded this time by agreeing to apply an "odor counteractant" (a deodorant). The Commission staff was convinced that more extensive controls on the company's cookers would be necessary, but still the Commission took no formal action that would lead to a judicially enforceable order. In 1969, the stench still emanated from Northern's plant. The Commission sent Northern a letter requiring a cleanup by November, but it then gave the company a thirty-day variance, ${ }^{103}$ thus suspending enforcement of its regulations during that period. Just prior to this action, a staff officer of the Commission had made another in a long line of site visits, and he later reported:

Every person interviewed felt that the odors from this plant were

102. Air Pollution Act § 8, Mich. Comp. Laws ANN. 336.18 (1967). The Air Pollution Act was enacted in 1965. Prior to that time jurisdiction was in the Department of Health.

103. The function of a variance under the Air Pollution Act is not clear. The statute provides that the Commission may suspend enforcement of any rule or regulation if enforcement would be inequitable or would create an unreasonable hardship, and that the Commission should take into consideration the progress that the person requesting the variance has made in eliminating air pollution. Air Pollution Act $\$ 819$. 20, Mrch. CoMr. LAws ANN. \& 336.29-30 (1967).

The statute also sets out a procedure for enforcing rules and regulations, which begins with issuance of a notice of violation and progresses through a hearing to a final order of determination. It seems that a final order is a prerequisite to invocation of penalties for a violation, and thus it is not clear why the Commission issues variances prior to the time that it issues a notice of violation. The polluting company does not appear to need a variance during this period to protect it from penalties. See tcxt accompanying note 185 infra. 
severe and resulted in an unreasonable insult to the community. I personally found the odors from this plant to be sickening at a distance of over a mile from the plant. ${ }^{104}$

After the counteractant failed to eliminate the odor, the company promised to build an afterburner (equipment the Commission had recommended), and the Commission granted an additional six-month variance during which time the afterburner was to be installed. ${ }^{105}$ Instead, without further notice or permission, the company installed a quite different kind of equipment that the Commission had not approved. This equipment failed to solve the problem.

At this point, spring 1970, the Commission activated its enforcement machinery for the first time. A notice of violation was issued, a statutorily required hearing was held; and in November 1970 the Commission issued a final order of determination that required the odor to be eliminated by May 1, 1971. On April 30, one day before the pollution control equipment approved by the Commission was to have been installed and operative, the company sought permission to install yet another type of equipment, a so-called wet scrubber. The long-suffering Commission gave its approval, but by June 1971 the staff, having visited the plant again, reported that "nothing has been done since the permit to install was approved by the Commission."106

Simultaneously with the expiration of the final order of determination, the company filed an application to the court for relief from the operation of the order, a tactic authorized by the procedureladen Air Pollution Act. ${ }^{107}$ The company did not prosecute its appeal, and the odor persisted as the summer of 1971 dragged on. The Commission, finally infuriated by this flagrant demonstration of its impotence, referred the case to the Attorney General for prosecution. The Attorney General took no action even though it was during the hot summer months that the odors from the plant were particularly noxious.

During this period, one of the public members ${ }^{108}$ of the Com-

104. Air Pollution Control Section, Staff Activity Report on Northern Reduction Co., Tannehill \& DeYoung, Inc., Sept. 11, 1969, at 2.

105. Kelley v. Tannehill \& DeYoung, Inc., Opinion of Judge Fitzpatrick at 4 (Feb. 9, 1972).

106. Conversation between an Air Pollution Staff Investigator and Roger Conner, notes on file with authors.

107. Section 13 of the Act, Mich. Comp. LAws ANN. § 336.23(2) (1967), permits a petition to be filed in the circuit court claiming that the order is "unreasonable or prejudicial." The Act also requires de novo review and places "the burden of proving the correctness of [the] ... order" on the Commission.

108. The member was Roger Conner, a co-author of this article. The Air Pollution Act $\& 3$, Mrct. Comp. Laws ANn. \$ 336.13(2) (1967) provides: "Of the 6 citizens so 
mission began taking steps to file suit himself under the EPA. The Attorney General entered the dispute when this member sought to obtain a supporting affidavit from Lee Jagar, the chief technical official of the Commission's staff; Jagar regretfully declined, reporting that the Attorney General's office advised him not to submit an affidavit for a private litigant, but to wait and make his affidavit for the state in the event that the Attorney General should decide to intervene on the side of the plaintiff.

For lack of an interested local lawyer, the proposed private suit was not filed, but the preparations for such a suit, which were known to a good many people-including members of the press-made apparent the need for the Attorney General to act. Finally, in October 1971 the Attorney General and the local prosecutor filed suit alleging a public nuisance and a violation of the EPA. The court granted a preliminary injunction on February 9, 1972.100

Undoubtedly, suit could have been brought in this case without the EPA; the law of public nuisance would probably have provided a sufficient cause of action, especially since the right to make such a claim is expressly preserved in the Air Pollution Act. ${ }^{110}$ The value of the EPA in such a case lies principally in its use as a psychological prod. By arming the ordinary citizen with authority to go to court, the EPA presses a reluctant public official to take action himself lest he be embarrassingly pre-empted. By setting out an unequivocal mandate authorizing judicial action, the EPA eliminates technical excuses that might be made to support inaction. ${ }^{111}$

Certainly, the EPA should not have been needed in Tannehill b DeYoung. Had the Commission moved more energetically, it could have obtained judicial action under the older Air Pollution Act. Likewise, the Attorney General might have filed a nuisance suit in the early 1960's. And, at the least, he could have been ready with a complaint to be filed on the first of May 1971 when the due date under the Commission's order arrived. Unfortunately, we live in a world of less than perfect regulatory action. It is for these situations that the EPA was enacted, and the Act has already indirectly paid a handsome dividend to the public in the form of a preliminary injunction against the Northern Reduction Company. ${ }^{112}$

appointed by the governor, 2 shall be representatives of industry $\ldots 2$ shall be representatives of local governing bodies ...2 shall be representatives of the general public."

109. See text accompanying notes 172-74 infra.

110. Air Pollution Act § 24, Mich. Comp. LAws ANN. § 336.34 (1967).

111. E.g., primary jurisdiction claims. See discussion of Chippewa County and Lakeland in text accompanying notes 77-101 supra. 1972).

112. Kelley v. Tannehill \& DeYoung, Inc., Decision of Judge Fitzpatrick Feb. 9, 


\section{Judictal Response}

\section{A. Cases Tried on the Merits}

\section{Payant $v$. Department of Natural Resources}

Even the most enthusiastic proponents of the EPA were reluctant to claim that the bill was desirable because it would give regulatory agencies an opportunity to vindicate controversial or unpopular programs in the courtroom. Yet that is precisely what happened in Payant v. Department of Natural Resources.

During legislative hearings on the EPA, the DNR had supported the bill, but with some reluctance. The DNR feared the consequences to some of its programs if private citizens could initiate suits. For example, the DNR had adopted a game management program for deer hunting that it believed to be scientifically sound. Yet the program was quite unpopular in some areas of the state. The DNR feared that a suit brought by private citizens to enjoin the program's enforcement would be tried before popularly elected local judges who might be responsive to community desires or who might be unable to appreciate the scientific evidence upon which the program was based.113

The only response that could be given the Department was that there was, indeed, a risk inherent in the bill; but it was a risk the Department ought to be willing to take to obtain the advantages the bill offered. Moreover, it was suggested that the DNR might be underestimating the professional integrity and competence of the judiciary.

Little did the DNR know how prophetic were its fears. Less than a year after the bill's enactment, suit was brought by a state legislator to enjoin the Department's deer-management program in Dickinson County, where public opinion was strongly opposed to the Department's allowance of antlerless-deer-hunting.

The immediate question raised by the case was whether limited. regulated hunting of antlerless deer helped or hindered the restoration of the state's declining deer population. People in the community felt that the prohibition of antlerless-deer-hunting until the herds were restored in size would be the most appropriate solution to this problem. The DNR, on the other hand, declared that the source of the problem was not hunters, but severe winters, overgrazing, and lack of adequate forage; the size of the deer population,

113. Letter from Ralph A. MacMullen, Director DNR, to Mrs. Donna Halversen, July 19, 1971, on file with author: "It is really too early to tell what the true effect of the law will be .... . Our earlier and only misgivings were that it could be used as a nuisance to curtail good game and fish management programs . . . ." 
they said, was limited by the carrying capacity of the habitat. ${ }^{114}$ In short, if hunters were not permitted to shoot the "excess" deer, the deer would die from starvation. Moreover, the DNR also took the position that there was an affirmative reason to allow hunting, for if too many deer were left to forage in an inadequate habitat, the food supply would be spread too thinly, and the deer population might be even further decimated.115

The underlying issues were in some respects more sophisticated. These included the question whether the DNR was properly calculating the carrying capacity of the habitats and the question whether it had been investing enough in habitat management to increase carrying capacity. ${ }^{116}$

Payant also posed the question whether the judiciary could respond in a timely fashion to a problem in which time was of the essence. Suit was filed on July 13, only 100 days before the 1971 hunting season was scheduled to open. The court promptly disposed of several preliminary motions, and the case went to trial on October 5. After two days the three-judge court issued an opinion that completely vindicated the DNR; the hunting season, therefore, went forward on time.

The unreported opinion merits considerable attention, for it reveals the court's attitude toward the importance of scientific evidence in environmental cases. In reaching its decision, the court noted:

The issue before the court is whether the defendant's program ... is likely to impair or destroy the deer herd [under section 3 of the Act]. Testimony introduced at the trial makes it clear there has been a steady decline of the deer herd. ...

Assuming that plaintiff made out a prima facie showing that defendants' program of taking antlerless deer is likely to impair or destroy the herd, the testimony introduced by defendants is overwhelmingly to the contrary. Such testimony was largely of a scientific nature given by trained and experienced personnel and greatly outweighs the evidence brought against it. The preponderance of the evidence convinces the court that the severity of winters in recent years and the lack of suitable food for deer ... are primarily responsible for the decline of the herd. The testimony further establishes that large numbers of deer have died in recent years due to the harshness of the winters, lack of food and consequent starvation; and that not only does the taking of a limited number of antlerless deer result in harvesting deer which would die anyway but it also

114. See Sunday Chronicle (Muskegon, Mich.), July 18, 1971, at 25, col. 4.

115. Id.

116. See Editorial, $A$ Closer Look at Deer Habitat Program, North Woods Call, March 8, 1972, at 6, col. 1 . 
is beneficial to the remaining deer in that they have a better chance of survival. The testimony of Louis Verme, a game biologist who has spent the last 18 years studying nutrition as it relates to the reproduction of deer, is particularly convincing. ${ }^{117}$

The significance of this opinion lies partly in the effect it should have on the confidence of the state regulatory agencies in the EPA: An examination of the trial transcript ${ }^{118}$ should set to rest their fears that local opinion, rather than demonstrable evidence, will govern the court. Perhaps more important is the fact that Payant clearly indicates that courts can handle scientific evidence concerning environmental matters.

An environmental trial, like any other well-litigated case, is an exercise in reducing great quantities of seemingly unrelated and contradictory data to a few critical issues, which will govern the court's ultimate decision. Payant demonstrated this point well. The plaintiff introduced statistical information about declining herds, the location and nature of forage, the causes of deer death, and the changing ratios of antlerless deer to bucks. It soon became evident that the DNR's program was largely based on claims of inadequate browse for the deer. The plaintiff then presented a number of witnesses-mostly local woodsmen-who testified that a great deal of browse was available, that the deer ate the browse, and that, indeed, there was more food available than was eaten. Several witnesses also testified that they had never seen a starved deer and that they had never known a fawn to survive when its mother had been shot. Moreover, it was noted that corn seemed to be an alternative food. source and that substantial amounts of corn had in fact been fed to deer in the area.

By this point, the plaintiff had highlighted the key issues for the court: How could it be said that deer were starving when great quantities of browse had been seen by witnesses? Were other sources of food, such as corn, available? And did the DNR's hunting program decimate the herds? The defendant DNR's witnesses, and especially Louis Verme, who was commended in the court's opinion, clearly and decisively put each of these contentions to rest.

First, Mr. Verme testified that in cold climates, like that of the Upper Peninsula, deer must often make a choice between adequate

117. Payant v. DNR, Opinion of Judges Brown, Munro, Davidson at 3 (Oct. 7, 1971).

118. We were unable to obtain a stenographic transcript in time so we listened to the court reporter's tape instead [hereinafter Payant Tape]. Summarization of trial testimony is based on the tape. 
food and good shelter. According to Mr. Verme, "Deer instinctively seek good shelter at the expense of food supply. In the Upper Peninsula deer experience extreme heat loss in travelling. And they need a tight canopy for shelter. They also need to hide, for deer are a prey species." 119 Deer in a severe climate, he added, will rarely travel more than a quarter-mile for food. Thus, even when it appears to a layman that the deer have adequate food nearby, in fact, there may be none readily accessible to them.

In addition, Mr. Verme testified that even if deer are eating, they may, nevertheless, be starving. While deer will eat anything, the important question to consider is the nutritional value of their food. Popple, for example, the browse in greatest abundance according to plaintiff's witnesses, is a poor deer food that is very low in nutritional content. "Fawns," Mr. Verme said, "who feed solely on popple browse for thirty days will die, and adults will experience severe damage ... . If there's not other food to supplement . . . we feel starvation conditions are occurring." 120 Thus, it is possible that "deer starve with their bellies full."

Mr. Verme also flatly denied the assertions that fawns die when their mothers are shot. According to Mr. Verme, fawns are completely weaned by the hunting season, and-Bambi stories to the contrary notwithstanding-they will compete with their mothers for food. A hungry adult doe will push her own fawn away to feed herself. With respect to the factual issue of corn-feeding, Mr. Verme totally rejected this method's usefulness. Corn is too rich a food for hungry deer, he said; it is, in addition, too expensive to make generally available and makes the deer too dependent, creating what Verme called a "barnyard effect."121

Perhaps the only point that was not neatly tied together by Verme's testimony was whether the DNR was doing enough cutting of adequate forage to reduce the problem. But even here, the defendant's witnesses were effective, for they noted the problems of restrictions on lumbering for forest products, the long time required for needed trees to mature, and the DNR's own efforts to improve forest management.

On the whole, no one who witnessed the Payant trial or examined the testimony could doubt that the DNR made an effective case without sacrificing detail and sophistication in the presentation of their testimony. Moreover, Payant serves as an illustration of how

119. Payant Tape, supra note 118.

120. Id.

121. $I d$. 
capable courts can be in managing a case within the enlarged judicial review of agency decisions required by the EPA. The Payant court did not uphold the DNR because the plaintiffs were unable to prove arbitrariness or caprice, or even because the agency's own record, standing alone, constituted substantial evidence to support its decision. Rather, the court permitted the plaintiff to make its prima facie case, and then put the burden on the agency to rebut that case as the EPA requires. ${ }^{122}$ This the agency was able to do by a preponderance of evidence. By accepting this larger burden and by meeting the plaintiffs directly on the merits, the agency emerged from the case stronger than ever. ${ }^{123}$

\section{Muskegon County v. Environmental Protection Organization}

Muskegon County had been the recipient of a much-praised federal grant to develop a regional sewage treatment system that used spray irrigation of partially treated water. The idea behind the project was to use the natural filtering process of land to treat waste water. However, fearing that doubters might interminably delay this important experiment with a last-minute lawsuit, the county sued a local organization that had been critical of the program, seeking a declaratory judgment that its plan was not a nuisance. ${ }^{124}$

As the plaintiff county predicted, the defendant organization counter claimed for an injunction under the EPA, and the issues were joined. The original suit was filed on March 15, 1971; there was one day of pre-trial hearings; and the case came to trial on May 4, 1971.125 On May 18, the court rendered a decision in favor of

122. EPA \& 3(1), MIcr. CoMr. LAws ANN. § 691.1203 (Supp. 1972).

123. See text accompanying note 64 supra.

124. The complaint, filed March 15, 1971, was brought against several named individuals and a local citizen group "individually and as representative of all persons having an interest in the establishment ... of the Muskegon County Wastewater Management System." Complaint at 1 . The idea was to prevent subsequent suits by others challenging the program. The defendant filed a motion for summary judgment on March 31, 1971, challenging the propriety of the class action on the grounds that there was no question commonly affecting the entire class of defendants, and that the named defendants "cannot possibly, represent" the class of defendants sought to be bound. Answer of Defendant at 5-6. The citizens abandoned this motion when the county conceded that a lawsuit filed after completion of the system on the ground that it was malfunctioning would not be barred by a decision in the instant case. See Muskegon County v. Environmental Protection Org., Transcript of Hearing on Defendant's Motion for Summary Judgment at 16-29 (April 20, 1971).

125. The defendants (and cross-plaintiffs suing under the EPA) objected to advancement of the trial on the calendar, which had been requested by the plaintiff under Mrar. CT. (GEN.) R. 521.4 (1969). The court offered a fifteen-day, and then a thirty-day, continuance, which defendants rejected as insufficient "without giving any 
Muskegon County. A motion for a new trial was denied on June 3, and the court's ruling was not appealed. The termination of the case cleared the way for the county's program to begin.

At the trial, the opponents of the spray-irrigation treatment plan built their case principally around three issues. ${ }^{120}$ They contended: that this treatment system operated rather like a large septic tank and that this system was discredited because it used infiltration into the soil as a waste disposal method; that the ground water level in this area was too near the surface for the filtering job to be effective; and that the soil in Muskegon, as contrasted with soil in other counties in which similar experimental programs had been carried out, was unsuitable for this type of project.

To each of these contentions, Muskegon County witnesses responded effectively. As for the first, they noted that septic tanks had two faults: they were anaerobic (lacking in oxygen during the period of decomposition) and they lacked means for controlling water flow and movement; but the county's witnesses further testified that neither problem existed in the county's proposed treatment works. As for the other contentions-the undesirable level of ground water and the unsuitability of the soil-the county's witnesses responded that these factors merely created greater engineering problems. This project, illustratively, had an elaborate drainage scheme to compensate for the high water table, and the soil in Muskegon County was described as not the best, but quite suitable.

On a number of other issues, the opponents of the plan were also unable to make any substantial headway. For example, while the spray-irrigation plan was conceded to be imperfect in handling certain nutrients that passed through the system, it was said to be considerably better than most other waste treatment systems. On such questions as what devices existed for dealing with system breakdown, the county adduced persuasive evidence illustrating that the Muskegon County proposal was much more flexible than conventional treatment plants.

reasonable explanation why such a continuance would not be sufficient." Muskegon County v. Environmental Protection Org., Opinion of Judge Piercey at 3 (May 18, 1971). Subsequently Judge Piercey inquired of the defendants' counsel whether a fortyfive-day continuance would be sufficient and defendants' attorney again gave the court no assurance that he would be able to present his additional proofs within such period. After due deliberation, the court denied defendants' motion for a continuance. Id. Sec also Opinion of Judge Piercey (June 3, 1971) (denying motion for a new trial).

126. Statements concerning trial testimony are the authors' summarization of an extensive transcript. 
The transcript demonstrates that the trial brought the essential issues out into the open with sufficient clarity that the court was quite able to handle them intelligently. The Muskegon County treatment plan was shown to be a well-considered and intelligent experiment for dealing with waste water. Although there may well have been preferable alternative sites, as the opponents suggested, there was no demonstration of any substantial reason to seek one out. A decision-making process can hardly be expected to do more than protect against significant and demonstrable mistakes.

\section{Crandall ข. Biergans}

The Crandall case $\mathrm{e}^{127}$ is noteworthy because it arose out of a simple common-law nuisance claim, a species of case that the judiciary has handled for centuries. The defendant operated a hog-finishing barn. The plaintiffs, who were neighbors of the defendant, claimed that the odors from the defendant's activities were intense. Other neighbors only seemed to find the problem mildly disturbing, and experts from both the Air Pollution Control Commission and the Department of Public Health testified that the odors were not severe.

Even if the plaintiff had prevailed on the odor issue, the case would no doubt have been lost, for the defendant demonstrated that there was no "feasible and prudent alternative."128 A number of experts testified that the defendant's barn was of a very modern design that effectively mitigated water pollution, rodent infestation, and aesthetic problems when compared with most hogfinishing operations. ${ }^{129}$ Alternatives suggested by the plaintiff, such as lagoons and so-called oxidation wheels, were firmly rejected by the defendant's experts. As to odor suppressants, it was shown that whenever a new product came on the market, the defendant had immediately contacted the manufacturer and had attempted to use the product as soon as possible. The alternative of moving the defendant's barn was demonstrated to be inadequate because it would only bring defendant's activities closer to other neighbors. In short, the defendant not only disproved the allegation that his activities constituted a nuisance, but established an affirmative defense permitted under the EPA as well.

127. See text accompanying notes 251-55 infra for excerpts from the court's extensive opinion vindicating the defendants.

128. EPA § 3(1), MICH. CoMP. LAws ANN. § 691.1203 (Supp. 1972).

129. Crandall v. Biergans, Tape of Trial, on file with author. 


\section{Tanton v. Department of Natural Resources}

Perhaps the most interesting case to come to trial yet under the EPA is Tanton v. Department of Natural Resources, ${ }^{130}$ in which the defendant DNR granted a developer a permit to dam Monroe Creek, a tributary of Lake Charlevoix, to create a lake around which residential housing would be built. The plaintiff proved at trial that the impoundment would have an adverse effect on trout fisheries. Yet, at the same time, it was clear that the development would have some compensating recreational benefits. There was little evidence that the DNR had compared and evaluated the benefits and losses. Thus, not only did this case raise the question of whether the defendant had met the affirmative burden of section 3(1) of the EPA, ${ }^{131}$ but -more importantly-the trial brought into question the DNR's land- and water-use policy. More specifically, the plaintiffs were asking the DNR to demonstrate that they had developed a policy against which the propriety of proposals, such as the one involved in this case, could be tested.

Indeed, the testimony of the DNR's Director, Dr. Ralph MacMullen, suggested that a quite different set of considerations guided the Department's decision. MacMullen conceded that he "would prefer that the land remain in its wild state ... [and] would prefer to have preserved the trout stream," but, "the alternative would have been uncontrolled development."132 MacMullen said that the proposed development was, as he viewed the problem, "the lesser of two evils": 133 Inasmuch as the developer's land was private property, his Department had no control over what would happen to it in the absence of a dam, ${ }^{134}$ and since the land might be sold to "unregulated and unpredictable developers, the kind that are ruining the north country," 135 the DNR ought to settle for the best environmental plan it can get under the circumstances.

130. We also have no transcript of Tanton. We did send a law student to attend the trial, and our impression of the case is based on his extensive notes [hereinafter Tanton Trial Notes]. See generally Charlevoix Couriex, March 15, 1972, at 1, col. 1. See discussion of Tanton in text accompanying notes 189, 233-36, 281-88 infra.

131. Mich. Comp. LAws ANN. § 691.1203 (Supp. 1972).

132. Tanton Trial Notes, supra note 130. See also Petoskey News Revicw, March 7, 1972, at 1, col. 1; Charlevoix Courier, March 8, 1972, at 1, col. 5.

133. Tanton Trial Notes, supra note 130.

134. Id. See Memorandum of Dr. MacMullen to Natural Resources Commission, Oct. 22, 1971, at 9-10, Exh. C to Complaint [hereinafter MacMullen Mem.]. Regarding the question whether an agency must consider alternatives beyond those that it has authority to put into effect, see Natural Resources Defense Council v. Morton, F.2d -, 2, BNA Env. Rep. Cases 1558, 1561-62 (D.C. Cir. 1972).

135. Tanton Trial Notes, supra note 130. 
Dr. MacMullen's testimony indicates that the DNR does not condition the granting of its permits on the basis of what is the best environmental plan for the area, ${ }^{136}$ but rather on the basis of what the DNR thinks might happen if the permit were denied. This approach requires the Department to engage in far-reaching speculation. For example, the evidence introduced at the Tanton trial indicated that the DNR based its decision not on concrete alternatives for development, but instead, on its estimate of what might happen if the land in question got into the hands of "unpredictable and unregulated developers."137 Moreover, it became clear under questioning by the judge that the DNR had made no study of local land use controls that could be used as a basis for an opinion about the DNR's authority to regulate other types of development of the land in question. ${ }^{138}$

To be sure, some risk is involved in judging a proposal on the basis of its current environmental acceptability, for one can never guarantee that a rejected plan might not lead to some other less desirable use. But the approach chosen by the DNR is considerably less attractive. For example, one could imagine the Public Service Commission approving an environmentally questionable pipeline route because the landowners over whose property the pipeline would run might subsequently decide to use that land for an even more destructive purpose, which might not be controllable.

It is in this setting that the judge in Tanton will have to interpret the EPA. Does the Act permit the DNR to make a "lesser evil" environmental decision, or must the Department use its permitgranting authority to evaluate the environmental impact of the particular plan before it? ${ }^{139}$ In confronting these questions, the court will have to take into account the fact that the validity of Dr. MacMullen's limited view of his legal authority is questionable. ${ }^{140}$

136. In the MacMullen Mem., supra note 134, it is stated that

If the area to be developed had been in the public trust, my decision would have been easy-hold on to it in its present state and do everything to lessen the impact of the hordes on it. However it is (for all practical purposes) in private ownership and the correct approach now is to control its development in such a way as to provide benefits to the public and a fair and just treatment to the present owners.

It should be clearly understood that we do not intend to consider this decision to be a precedent for other apparently similar cases.

137. Tanton Trial Notes, supra note 130.

138. Id.

139. In addition, the Dam Act $\S 2(\mathrm{~b})$, Mich. CoMp. LAws ANN. \& 281.132(b) (Supp. 1972), provides that a permit may be issued if "the presence of an impoundment will not have a significant adverse effect on fish, wildlife or recreational values in the watershed or infringe on the public rights in the waters of the state."

140. Nor is his view of the deference due land developers (see supra note 136) as 
Dr. MacMullen appears not to have considered the affirmative authority granted him by the EPA to challenge some other proposed use of the land in question should the dam permit be denied; nor has he taken into account the availability of the extensive traditional powers the Attorney General has in the area of public nuisance, the potential of other statutes such as the Water Resources Act, ${ }^{141}$ or-as noted above-local land use controls, as devices to prevent egregious alternative land uses.

In contrast to the DNR's timid view of its legal authority to deal with potentially destructive land uses, it should be noted that just weeks before Tanton went to trial, the Governor's Special Commission on Land Use issued a report. The following comments appeared in the summary of the report:

[T] he state should review major land sales to ensure adequate planning and to protect the natural resources and land areas with unique values. Existing departmental rules and regulations should be closely examined for use in this area of environmental abuse. . . .142

Furthermore, the Report stated: "It is impractical to wait for the adoption of a state land development plan as a precondition for state regulation, and delay all action pending comprehensive plan development. ...."143 Moreover, after Tanton had been initiated, but prior to the trial, the Natural Resources Commission unanimously pledged that it would "not in any way abet"144 new water

a constitutional matter necessarily correct. See Sax, Takings, Private Property and Public Rights, 81 YaLE L.J. 149 (1971). See notes 144, 189 infra.

141. See note 75 supra.

142. Summary OF REPort of Governor's SPEctal Commission ON LAND Use 6 (1972) (emphasis added).

143. Report of Governor's Special Commission on Land Use 14 (1972).

144. State Journal (Lansing), Jan. 14, 1972, at B-2, col. 1. The Natural Resources Commission and the DNR appear to have taken a much broader view of their au. thority, in talking to reporters, than the DNR did in testimony in Tanton. It was stated in the Detroit Free Press, Jan. 15, 1972, at 3-A, col. 5 that

[t] he Commission pledged that it and the D.N.R. will withhold approval from all private and public developments which are held to have the "potential to cause major irreversible damage to the quality of Michigan's environment."

... A. Gene Gazley, assistant D.N.R. director ... said the policy will allow the D.N.R. to be "much more effective" in dealing with the problem of cheap, haphazard development occurring in many northern areas of the state. . . .

The Commission pledged that in implementing the new policy it would act to the limit of its statutory authority. In attempting to discourage projects over which it lacked direct authority, the Commission promised that "all other means-persuasion, publicity, moral force-will be employed to prevent or at least mitigate environmental damage."

Commission chairman Harry H. Whiteley said "from now on they (the developers) are really going to have to sell us" before the Commission or the D.N.R. will approve development proposals.

See also North Woods Call, Jan. 19, 1972, at 1, col. 1. 
or land uses that could damage the environment. As the State Journal noted in its story on the Commission's action:

The interim land use policy was adopted in the wake of a report by Gov. Milliken's Special Commission on Land Use urging statewide land control.

Ironically, the approval came a day before an Ingham County court test of the Commission's December decision to permit a 440acre impoundment of Monroe Creek in Charlevoix County. ${ }^{145}$

\section{Lakeland Property Owners Association v. Township of Northfield}

In Lakeland Property Owners Association v. Township of Northfield, the plaintiffs challenged the present operation and plans for enlargement of a local waste water treatment plant. ${ }^{146}$ The testimony in the case was extensive and detailed, but the weight of evidence was not as clear-cut as in Payant or Muskegon County. The judge appeared also to be affected by the cavalier attitude of both the Water Resources Commission and the Department of Health in dealing with the plaintiff's complaints. Before and after construction of the treatment facility, officials from both agencies made representations to members of the plaintiff community that were not carried out; indeed, during the trial it was revealed that the letters had been consigned to a dead file. ${ }^{147}$ Moreover, the WRG upgraded its Final Order of Determination during the pendency of the litigation, obviously in response to the suit. This course of action is hardly likely to inspire confidence in the "scientific" nature of the WRC's judgments. 148

Besides being influenced by the plaintiffs' evidence that the receiving waters were polluted and that compliance with the WRG standards would continue to produce polluted water, the judge was obviously concerned about the testimony by defendants' witnesses that there were multiple sources of pollution and that tightening restrictions on this plant alone would not be sufficient to clean up the receiving waters. The court's opinion repeatedly noted, when referring to testimony by defendants' expert, that

[the witness] did not know if stopping all phosphates from de-

145. State Journal (Lansing), Jan. 14, 1972, at B-2, col. 1. Because Judge Reisig granted the defendants a change of venue from Ingham to Charlevoix County, the case did not go to trial until March 6, 1972.

146. See text accompanying notes 91-101 supra, 261-66 infra.

147. Authors' trial notes.

148. See text accompanying note 97 supra. 
fendant plant would make any appreciable difference with regard to Strawberry Lake. . . . It was [his] further testimony . . . that if the defendants herein comply with the amended final order of determination and damage is still being done to the receiving waters because of nutrients, the levels in the order could be ordered "adjusted" or the complaint ignored even though the "standards" are being abused. ${ }^{149}$

The court no doubt concluded that the Water Resources Commission was reluctant to deal with any one polluter in light of the fact that effluents discharged by others also contributed to pollution. The court was also unimpressed by the defendants' notion that they were relieved of responsibility because individual homeowners downstream were also polluting. Furthermore, the court determined that the defendants had not made out an affirmative defense other than by assertion. It noted:

$[D]$ efendants merely recited, through their witnesses, that there was no reasonable and feasible alternative to their actions and did not support such recitations with facts other than alluding to economic considerations. Defendants also admitted ... that present and future population below the outfall pipe had not been taken into consideration at the original construction of their waste water treatment plant and apparently is being ignored currently upon their request to continue operation and expand the volume of their discharge. ${ }^{150}$

A judgment was thus entered for the plaintiffs that included more restrictive effluent standards, but allowed as alternatives the reduction in total discharge and the establishment of a less harmful site for waste discharge.

\section{B. Restraining Orders and Preliminary Injunctions}

Preliminary relief has been at issue in about one third of the cases filed under the EPA. In nine cases hearings were held on plaintiffs' motions for restraining orders or injunctions; the relief sought by plaintiffs was granted in four of those cases, ${ }^{151}$ and denied in five. ${ }^{152}$ There are, in addition, four cases in which ex parte tem-

149. Lakeland Decision of Feb. 29, 1972, supra note 95, at 13-14.

150. Lakeland Decision of Feb. 29, 1972, supra note 95, at 22.

151. Ray v. Raynowsky; MUCC v. Anthony; Lakeland Property Owners Assn. v. Township of Northfield; Kelley v. Tannehill \& DeYoung, Inc.

152. Surowitz v. City of Detroit; Alvin E. Bertrand, Inc. v. City of Detroit; Blunt v. Apfel; Wilcox v. Board of Rd. Commrs. (the court of appeals in Wilcox ordered the injunction reinstated pending trial; see note 170 infra); McCloud v. Gity of Lansing (injunction denied but jurisdiction retained to assure defendant's compliance with a promise to screen and to place underground a challenged power line in a park; Order of Judge Reisig at 2 (May 17, 1971)). 
porary restraining orders have been issued; ${ }^{153}$ and in one other case the plaintiff has not yet pursued his ex parte motion. ${ }^{154}$

Motions for preliminary relief are among the most important tests of judicial competency in handling EPA cases, for it is at this stage that the judge's power is greatest: Before all, or even a substantial amount, of the data in the case is available, the court must decide upon whom the practical burden of the litigation is to be placed. The cases brought thus far show that judges are not wildly issuing injunctions to save the environment, oblivious to the interests of defendants; preliminary injunctions sought by plaintiffs have been denied as often as they have been granted. But this bare statistic is only the beginning of the story, for the judges before whom these motions were argued have acquitted themselves quite well, as the cases illustrate. ${ }^{155}$

Surowitz v. City of Detroit was probably the least-prepared case brought under the EPA. The plaintiffs sought to enjoin the City of Detroit from using the pesticide methoxychlor, a widely accepted substitute for DDT, for the control of Dutch elm disease. The plaintiffs sought an ex parte restraining order, but the judge quickly scheduled a hearing on a temporary restraining order the day after the complaint was filed. At the hearing, the city offered letters from both the State and Federal Departments of Agriculture, and from academic experts as well, that indicated approval of the use of methoxychlor. ${ }^{156}$ The plaintiffs could produce no hard evidence of harm, and they only suggested weakly that the city needed to do more research on the insecticides. Indeed, it was even brought out at the hearing that one of plaintiffs' own witnesses had recently recommended the use of methoxychlor as a substitute for DDT.

Judge Foley denied plaintiffs' ex parte motion, noting-perhaps

153. Leelanau County Bd. of Commrs. v. DNR; Gang of Lakes Env. Org. v. Gee; Tanton v. DNR; Trout Unlimited v. Milliken. In Trout Unlimited $v$. Milliken the order led promptly to negotiations and a consent order disposing of the case. In Leelanau, the judge held that the case was not yet ripe because the legislature had not yet authorized the transfer of state park land to the United States. In Gang of Lakes, the defendant has not rushed to proceed to a hearing. In Tanton, the defendant developer was eager to argue for the dissolution of the order, but he was temporarily delayed by his own successful motion for a change of venue from Lansing to Charlevoix, where the judge urged that the full case be brought to trial promptly and held the order in effect until then. The trial was held in March 1972, three months after the ex parte restraining order was granted and about six weeks after the change of venue was allowed.

154. WCHD v. National Steel Corp. infra.

155. See discussion of Blunt v. Apfel, in text accompanying notes 178-80, 307-08

156. Authors' notes taken during hearing. See Surowitz v. Gity of Detroit, Transcript at 2-3 (April 14, 1971). 
more tolerantly than the slapdash presentation of the plaintiffs warranted-that

[w]e have ... an involved question raised in a new area, dealing with ecology, and ... the research is in its infancy. . . We have $[210,000]$ trees ... dying at the rate of 10,000 a year. If nothing is done this will double by next year. ... This is the problem that the Gity was faced with. . . Every indication to this Court at this time is that the City is using every precaution to carry out a properly controlled program. There is no evidence to the contrary. And I appreciate the testimony here today by the experts, because they have pointed up that a great deal of work is necessary ... because we just don't know. . . . But I don't have any facts before me upon which I can enjoin the City from a program which is almost necessitated, dictated by the emergency they are faced with, and I don't have facts which indicate that this will cause harm to persons or animals or fish.

... I am going to deny the request for injunctive relief at this time, but ... rather than dismiss the case ... the case should be left pending. ... If during this period some conclusion can be arrived at which would support the allegation ... then come in and ask for injunctive relief, and I am pretty sure it would be agreed to. ${ }^{167}$

Alvin E. Bertrand, Inc. v. City of Detroit was a suit to enjoin the operation of a municipal incinerator used to burn pathological wastes. Plaintiff alleged that the city's incinerator was emitting particulate matter many times in excess of the Health Department's minimum standards. At the hearing on plaintiff's motion for a preliminary injunction, the city argued that the particular wastes fed into this incinerator could not be put in a landfill, and that it had already closed down three of its four incinerators and was presently trying to eliminate or modify this facility. ${ }^{158}$

Apparently hoping to put additional pressure on the city to develop a prompt abatement plan, the judge adjourned the hearing for sixty days without ruling on the prayer for interim relief. He explained to the press that "[i]f the incinerator is absolutely necessary, I don't want to order it closed," but he added that if the city could not abate the pollution, he might, at a later time, shut it down. ${ }^{169}$ At the second hearing, the city steadfastly maintained that no quick solution was obtainable, and plaintiff's witness testified that the emissions were only slightly in excess of the applicable limits. The judge, therefore, responded that interim relief was inappropriate and ordered the matter set for trial.180

157. Surowitz Transcript, supra note 156, at 2-4.

158. Detroit Free Press, October 23, 1971, at 5-A, col. 2.

159. $I d$.

160. Conversation between Kenneth Prather, counsel for plaintiffs and author, Jan. 17,1972 . No order has yet been signed by the court. 
Both Bertrand and Surowitz suggest not only that judges use common sense in resolving these cases, but that they are willing to go beyond their formal responsibilities and to use the leverage of their position to induce litigants to take further steps to alleviate the problem. For example, the maintenance of jurisdiction, without the issuance of a restraining order, would seem to indicate that judges are often sensitive to the dynamics of public decision-making as well as to their more narrow professional duties.

In Ray v. Raynowsky, plaintiffs brought suit to enjoin a proposed land drainage project. Work was to have begun in early November 1971 when the case was filed and an ex parte restraining order granted; the defendants filed a motion to dissolve the order, and the judge brought that motion on for a hearing one week later. ${ }^{161}$

Raynowsky raised a pervasive problem in environmental litigation. The county drain commissioners were proceeding with their land drainage project in the established way-proposing a stream channelization. ${ }^{102}$ Plaintiffs urged that there existed a more sensible solution-the creation of small ponds-that would be less harmful to the water table, to wildlife, and to pollution drainage into the rivers. They asked for an opportunity to put their proposal before the court for examination and comparison.

At the hearing on defendants' motion to dissolve the restraining order, the judge adopted a position that seems to be commonly taken in EPA cases. He was reluctant to "try" the case twice;"163 thus he both encouraged and promised the parties an early trial on the merits. ${ }^{104}$ As a result, at the dissolution hearing he concerned himself with only two questions: Would there likely be irreparable harm if the order were dissolved in the interim, and was there any urgent need for the defendants to go forward with their plan? Satisfied that the answer to the first question was yes, and to the second no, he allowed the restraining order to stand. ${ }^{165}$

Wilcox v. Board of Road Commissioners was one of the few disappointing preliminary injunction cases. The plaintiff sought to enjoin a county road commission from undertaking a highwaywidening that would require cutting down nearly a thousand old oak and maple trees. There was little, if any, indication that the Commission had undertaken a study in search of less damaging al-

161. Ray v. Raynowsky, Transcript (Nov. 23, 1971).

162. Reume v. Herrick and Gang of Lakes Env. Org. v. Gee challenged similar conduct by Drain Commissioners. A restraining order was issued in Gang of Lakes on Jan. 19, 1972.

163. See note 30 supra and accompanying text.

164. Ray Transcript, supra note 161, at 16.

165. Id. at 24-26. Trial was held on June $19 \& 20,1972$. 
ternatives. Accordingly, the case seemed an ideal vehicle for bringing the conduct of one of these local-and traditionally environmentally insensitive-agencies into the open. ${ }^{100}$ An ex parte restraining order was obtained in mid-1971, ${ }^{167}$ and the case was not brought on for hearing by the defendant for eight months. But on February 18, 1972 , the court held a hearing ${ }^{168}$ at which it denied plaintiff's preliminary-injunction motion:

It appears to this Court that although the defendant intends to cut down numerous trees, it is necessary to do so if the present plans for the improvement of Duck Lake Road are to be carried out. There appears to be good reason for making the proposed improvements. Defendant has made a good showing that the health, safety and welfare of the public should be protected by widening the . . . road. ... On balance, the protection of the health and safety of the traveling public on the highway outweighs the esthetic quality of the environmental conditions.

... Over the past three years defendant has experienced an increase in costs of road construction. . . . The defendant has made a showing that it will be subjected to material ultimate damage and deprivation of rights if the injunction continues. Neither can it be said, absolutely, that there will be an unnecessary destruction of natural resources if the trees are cut down as planned.

Balancing the possible benefits to the public to have the trees remain standing as against the benefit to the public in having an improved highway, it appears to this Court that a preliminary injunction should not be issued.169

Unless the judge found that safety considerations mandated a prompt widening of the road, his denial of the injunction seems to be contrary to the legislative intent behind the EPA. If the construction went forward, the case would become moot before it could ever go to trial on the question whether there were "feasible and prudent alternatives," an issue that was ignored in Judge Ryan's opinion. Indeed, the only ground he specifically mentioned for denying the injunction pending trial was inflation in the costs of roadbuilding. It is not surprising, therefore, that the plaintiff immediately appealed and that the injunction was reinstated by the court of appeals pending trial. ${ }^{170}$

166. For background on the case, see Jackson Citizen Patriot, Aug. 8, 1971, at 1, col. 1.

167. Wilcox v. Board of Rd. Commrs., Order of Judge Ryan (June 16, 1971).

168. We have not, at this time, been able to obtain a copy of the hearing transcript.

169. Wilcox v. Board of Rd. Commrs., Finding of Judge Ryan at 4-5 (March 1, 1972).

170. The court of appeals ordered, pursuant to Micr. CT. (GEN.) R. 806.7 (1969), that the preliminary injunction be reinstated "pendente lite for the purpose of pre- 
In two other cases, courts granted preliminary injunctions that seemed plainly appropriate in light of the existing facts. One was issued in Lakeland.171 The court enjoined the expansion of a sewage treatment plant and prohibited new customers from tapping on to the system until a trial could be held. That case has now been decided in favor of the plaintiffs after a full trial.

The other injunction was issued in Tannehill \& DeYoung, the case involving the notorious rendering plant in Traverse City that had slipped out of every effort to bring regulatory enforcement into play for eight years. ${ }^{172}$ One could hardly imagine a case in which immediate judicial action was more appropriate. ${ }^{173}$ In issuing the preliminary injunction, the court said in part:

Plaintiffs produced nine witnesses ... whose testimony was that the odors emanating from the Defendant's plant ... has [sic] been obnoxious, uncomfortable, offensive, disagreeable and nauseating. No witnesses were produced by the Defendant to counteract or contradict the testimony given by . . . the Plaintiffs. . . . Witnesses in managerial positions of two large Traverse City motels testified that they had received numerous complaints from guests... regarding these odors.

Lee Jager, ... head of the Air Pollution Control Division of the Michigan Department of Health ... testified that he has received over 100 complaints regarding the odors and that he has made more than 10 visits to the plant, the first being in $1963 \ldots$. . Defendant requested and was granted a permit to install odor reduction devices known as after-burners. ...

....

... The Court has purposely delayed rendering a decision in this matter to give Defendants every opportunity to completely install and have operable their latest proposed control device to demonstrate claims made for it but to date [the court] has not been informed that the same is in operation. Hence the Court feels that it can no longer permit the situation to exist....

....

... [A] temporary injunction ... shall be issued which will tem-

serving the status quo pending a determination on the merits at trial." Wilcox v. Board of Rd. Commrs., Order of Judges Holbrook, Burns, and Fitzgerald, No. 13835 at 1 (Ct. App. at Grand Rapids, March 31, 1972).

171. See text accompanying notes 91-101 supra, 261-66 infra.

172. See text accompanying notes 102-12 supra.

173. A final absurdity occurred when the defendant's expert lied about his credentials during the preliminary examination hearing. The court held him in contempt, fined him \$250, and sentenced him to ten days in jail for each lie. Kelley v. Tannehill \& DeYoung, Inc., Order of Judge Fitzpatrick (Feb. 7, 1972). The jail sentence was suspended upon payment of the fine. 
porarily enjoin Defendant from conducting rendering or other similar operations . . . . ${ }^{174}$

Michigan United Conservation Clubs $v$. Anthony, the Indian fishing case, ${ }^{175}$ involved the most extensive hearing on a motion for preliminary injunction. The plaintiff presented a fisheries expert from the DNR, whose testimony set the stage quite effectively. Beginning with the historic decline in Great Lakes fisheries and the difficulties in enforcing regulations, he quickly sketched the problem's background. ${ }^{176} \mathrm{He}$ then described the nature of present regulations, the way in which the Indians were violating those regulations, and the risk their violations presented to the management areas in which these Indians were fishing. The witness was temperate and cautious. He did not assert that the Indian fishermen were creating some imminent risk of destruction of trout throughout the Great Lakes. He did, on the other hand, maintain that fisheries were quite localized and that in the particular areas where the defendants were operating, their activities were consequential. He noted, too, that only a few Indians were doing the bulk of large-scale commercial fishing so that issuance of an injunction would not have widespread effects on a substantial community of persons.

The defendants produced no witnesses of their own, but instead relied upon their cross-examination of the plaintiff's witness. Counsel for the defendants pressed the point that the Indian defendants were doing only a modest part of the entire Great Lakes fishing, and thus tried to suggest that an injunction against them could hardly be a significant factor for fisheries management. But the plaintiff's witness re-emphasized that fisheries were quite localized and that within those regions where defendants did fish, their impact was substantial.

The hearing did not finally resolve the question whether damage to fisheries should be considered on an area-by-area basis or in terms of the lakes as a whole, but the plaintiff did accomplish what it had set out to do. It had educated the judge about the nature of the problem and demonstrated that continued Indian fishing in violation of state regulations might significantly deplete an important resource. As in the other injunction cases, the judge seemed quite capable of understanding the environmental problem. Subsequently the judge commented to the press, "If I had waited until a trial, it

174. Kelley v. Tannehill \& DeYoung, Inc., Decision of Judge Fitzpatrick at 2-0 (Feb. 9, 1972).

175. See text accompanying notes $49-57$ supra, 290-97 infra.

176. MUCC v. Anthony, Transcript at 47-52 (Aug. 18, 1971). 
would be closing the door after the cows were stolen. My idea is to preserve the fish for both the Indians and the white man."177

Another EPA case, Blunt v. Apfel, illustrated how a motion for a preliminary injunction may fail to make effective use of the EPA's potential. Defendants were planning to build a condominium on the shores of Torch Lake in Antrim County, but plaintiffs, who were principally concerned about pollution from sewage, sought an injunction to prevent the construction. ${ }^{178}$

The case was potentially fascinating because the issue of lakeside recreational developments is very important in Michigan and has been the subject of considerable litigation. ${ }^{179}$ Blunt was also of interest since, unlike earlier litigation, it involved a lake that was not yet overdeveloped. Blunt thus sought to bring some management to the lake's development at an early stage-something from which many Michigan lakes could have benefited years ago.

Unfortunately, Judge Brown's attention seemed riveted to the fact that no harm had yet taken place. On a number of occasions he referred to the case as being one of "mere apprehension or fear." 180 Both lawyers limited themselves to the submission of a

177. State Journal (Lansing), Sept. 16, 1971, at A-1, col. 7-8. The court of appeals at Lansing (Judges Quinn, Bronson and Danhof) denied the defendant's application for leave to appeal from the grant of the preliminary injunction, Nos. 1318 \& 1319, Jan. 19, 1972. Trial of the case in the circuit court is scheduled for July 25, 1972.

178. The case became quite complicated. Plaintiffs filed two amended complaints, alleging violation of both riparian rights and a zoning ordinance, which had been en. acted during the pendency of the suit. Both of these issues were ultimately dismissed by the court, but jurisdiction was retained over the original EPA allegations. Blunt v. Apfel, Decision and Order of Judge Brown (June 10, 1971) (dismissing plaintiffs' claims). When the developer commenced construction without a permit from the Township Zoning Commission, the Township brought a criminal action. Judge Brown, who was presiding in Blunt, enjoined the criminal proceeding in an action brought by the developer against the Township. Ware Real Estate Corp. v. Forest Home Township, No. 880, (Cir. Ct., Antrim County). This suit was consolidated with Blunt. Order of Consolidation (March 15, 1971). Subsequently, the township agreed not to enforce the zoning law if the developer would agree not to challenge the law's validity in court and to pay the $\$ 400$ required for a permit. The property owners appealed the permit approval to the Board of Zoning Appeals. In any event, Judge Brown in his Order of June 10,1971, held the zoning ordinance unconstitutional as applied to this developer. The developer filed a damage action against the plaintiffs. Apfel v. Cook, No. 926 (Cir. Ct., Antrim County).

As a collateral matter, the Securities Bureau, refused to grant the developers a permit to sell the twenty per cent of the units that have already been built. Presently, it is not certain whether, or when, the case will be tried. Settlement negotiations appear to be on the horizon.

179. See, e.g., Thompson v. Enz, 385 Mich. 103, 188 N.W.2d 579 (1971); Pierce v. Riley, 35 Mich. App. 122, 192 N.W.2d 366 (1971); Opal Lake Assn. v. Michaywe Ltd. Partnership, No. 13599-C (Cir. Ct., Ingham County, Jan. 4, 1972).

180. Blunt v. Apfel, Decision and Order of Judge Brown at 3-4 (Dec. 16, 1970) (denying preliminary injunction).

Counsel for the plaintiffs admit there is no pollution as yet but contends the approved plans and requirements are insufficient .... Act 127 (the EPA) ... is 
single affidavit from an expert, and both affidavits were brief, uninformative, and conclusory. No witnesses were called. The opportunity to offer evidence on the importance of avoiding irreversible harm was lost.

\section{Impact of the EPA ON Administrative AND INDUSTRIAL BEHAVIOR}

To evaluate fully the EPA's contribution to environmental regulation, it will be necessary to look beyond courtroom proceedings and to examine the effects of the statute on the day-to-day operations of regulatory agencies and industries in Michigan. Cases actually litigated at most can only touch the range of environmental problems. If the statute is to succeed, it must energize entrepreneurs and agencies through the threat of potential litigation into doing their jobs more conscientiously.

While no such inquiry has been undertaken by the authors, there is some suggestive, anecdotal evidence that the statute has caused agency behavior to change. ${ }^{181}$ The Air Pollution Control

\footnotetext{
extremely broad in scope by granting the right to any person to start an action alleging a defendant is likely to pollute ....

The burden of proof is on plaintiffs to at least make a prima facie showing and mere apprehension or fear that defendants "might" pollute the waters .... and that present standards ... approved by the Department of Natural Resources ... are inadequate, is, in the opinion of this Court, insufficient to effect such a prima facie showing, in view of defendants' evidence to the contrary.

Equity will not interfere in advance of the creation of a nuisance, where the injury is doubtful and contingent ....
}

See Transcript at 15, 29 (Dec. 10, 1970). Note that in Leelanau, Judge Brown seemed to take a more sympathetic view of the EPA's effort to deal with environmental dcgradation before it passed the point of no return. In an Order denying Defendant's Motion for Summary Judgment at 2 (June 14, 1971), he noted that "[t]he Michigan Environmental Control [sic] Act specifically provides action may be started ... where the alleged violation has occurred or is likely to occur. . . " Because the legislature had not yet authorized the transfer of the land in question, he adjourned the case temporarily. His opinion suggests that he intends to adjudicate the matter at the time the transfer is authorized, rather than wait until actual degradation takes place.

Note also that the "likely to pollute" language of § 3(1) of the EPA is similar to \$ 6 of the Water Resources Commission Act which makes unlawful a discharge that "is or may become injurious." Mrch. Comp. LAws ANN. \&323.6 (1967), as amended (Supp. 1972). See the Opinion of the Attorney General, No. 4721, June 7, 1971. See note 199 infra.

181. For example, the State Journal (Lansing) carried a story on April 5, 1972, at B-5, col. 5, stating that

[w]ary of a possible lawsuit, members of Livingston County's Department of Public Works may set up a close monitoring system on water quality at Thompson Lake. ...

. DPW members have taken careful note of a recent ruling by the Livingston County Circuit Court [Lakeland] ....

They are reasonably certain the Red Oaks Plant can meet most of the purity standards Judge Paul R. Mahinske imposed [in Lakeland] ....

If the question of pollution by the Red Oaks plant is ever raised in court . . . DPW members want to have statistics which can point the blame at some other source. 
Commission provides one such illustration.

From its creation in 1965 until 1971, when West Michigan Environmental Action Council v. Betz Foundry, Inc. ${ }^{182}$ was filed, the Air Pollution Control Commission issued final orders of determination in only two cases, preferring instead to negotiate pollution control programs and to grant "variances in the interim."183 The weakness of this procedure appeared whenever a violator failed to live up to his agreement; the time-consuming process of issuing a complaint, holding a hearing, and adopting a final order was required before court enforcement could be initiated.

Betz-the first EPA suit naming the Air Pollution Control Commission as a defendant-apparently caused a departure from that practice. Following initiation of the lawsuit, the approval of an application from another company seeking a variance was delayed by the Commission pending further staff investigation. Previously such applications were routinely granted. But Commissioner Stanley Quackenbush has since remarked that such applications would be scrutinized with greater care lest the Commission be brought into court again, ${ }^{184}$ and soon thereafter, the Commission adopted a new procedure under which it increasingly issued complaints and pressed for orders, rather than the informal agreements embodied in a variance. ${ }^{185}$

To be sure, this change cannot be attributed solely to Betz. The variance procedure was previously under attack from both the public and from some members of the Commission. Tannehill of DeYoung, Inc. ${ }^{186}$ had also contributed to the Commission's embarrassment. But at the least, Betz provoked reconsideration of the Commission's procedures. It was often discussed in formal and informal Commission consideration of the variance issue, ${ }^{187}$ and it was clearly an important factor in the new procedure that has been adopted.

A controversial proposal to build a harbor at the mouth of the Platte River provides another example of the manner in which agency behavior has changed since the EPA was adopted. The project had been supported by the DNR, but opposed by conservationists whose

182. See notes 34 \& 94 supra.

183. See note 103 supra.

184. Authors' notes of the Air Pollution Control Commission meeting, March 16, 1971, and tape of the meeting made by the Commission staff.

185. Minutes of the meetings of the Air Pollution Control Commission, Feb. 16, 1971; July 20, 1971; Aug. 17, 1971.

186. See text accompanying notes 102-12, 172-74 supra.

187. Roger Conner, a member of the Commission, was a participant in the discussions. 
objections were strong, but seemed unavailing. The issue reached a climax when plans were made to file a suit under the EPA that would challenge the project. According to newspaper reports, the anticipated suit played an important role in persuading the DNR to reconsider, and ultimately abandon, its plan. ${ }^{188}$

The DNR's decision on the Platte River project was also affected, no doubt, by the highly publicized Tanton case. ${ }^{189}$ Indeed, there is every reason to believe that Tanton was the motivating force in the Natural Resource Commission's formulation of its potent, new land use policy, and it was this policy that the DNR used when making its Platte River decision. ${ }^{100}$

A questionnaire we sent to attorneys handling EPA cases ${ }^{101}$ produced some interesting responses about the regulatory agencies' behavior since the EPA's enactment. The first two comments are from plaintiffs' attorneys:

188. Fulton, Platte Saved-Battle Leaves Bitter Taste, Ann Arbor News, Feb. 27, 1972, at 35, col. 6; Digest, Michigan Department of Natural Resources, Feb. 1972, at 1.

189. See text accompanying notes 130-45 supra, 233-36, 281-89 infra. Newspaper accounts include Serrin, State Dilemma: Wilderness v. Homes, Detroit Free Press, Jan. 13, 1972, at 3A, col. I; Editorial, State's Environmental Act Faces Major Test, Midland Daily News, Jan. 18, 1972, \& 1, at 8, col. 1; Editorial, Only Courts Can Now Save Our North Woods, North Woods Call, Dec. 22, 1971, at 4, col. 1.

The DNR's "environmental reputation" was at stake in Tanton. The State Journal (Lansing), Jan. 19, 1972, at A-8, col. 1, carried an editorial entitled D.N.R. Takes Odd Stance in Dispute, which stated in part:

Growing abuse in land development ... has been spotlighted recently by recommendations of a governor's commission. . . .

While the commission struggles with this approach, the D.N.R. seems, ironically, to be going in the opposite direction.... It is somewhat astonishing to find the D.N.R. defending itself in such an action [Tanton]. More difficult to understand is the fact that the D.N.R. approved the dam and lake project in spite of the fact that its own staffers in the Charlevoix area opposed it.

Dr. MacMullen immediately wrote a Ietter to the Editor, State Journal (Lansing), Jan. 28, 1972, at A-6, col. 6, in which he responded:

The editorial unfortunately exemplifies a worrisome tendency on the part of the communications media to take positions on matters of principle without full knowledge. ...

Like most issues, this one was not 100 per cent clear-cut; in my judgment it was more like $55-45$ in favor. Thus it is not surprising that some D.N.R. employees and two of the five commissioners took a contrary view. . .

Time and the Courts will tell whether the Monroe Creek decision was right or not. I think it was, but I make no claim to infallibility.

190. See notes 144-45 supra and accompanying text; North Woods Call, Jan. 19, 1972, at 5, col. 2:

The policy was drafted by the DNR following its approval in December of an impoundment and land exchange which would open the door for a 1,300-home subdivision on Charlevoix County's Monroe Creek. Commissioner Gus Scholle recommended that the department adopt a new, broader policy to regulate and limit land development after the Monroe Creek action was taken.

The complexity of efforts to analyze these problems in terms of cause and effect is revealed by the subsequent Escanaba River controversy. See Cooper, State Approves UP River Project, Detroit Free Press, June 2, 1972 at 3-B, col. 3. Cf. Foster v. DNR, No. 9906-C, Opinion of Judge Reisig (Cir. Ct., Ingham County, May 31, 1972).

191. See Appendix I infra. Because we promised the respondents anonymity, the responses are not identified. All responses are in the authors' files. 
My case involved W.R.G. standards and witnesses . . . I think that this heightened their concern for their own standards and procedures. Having them called into question .... seemed to sting.

Our case involved three administrative agencies ... the Department of Natural Resources, the Michigan Department of Health and the Securities Bureau. With respect to the former two agencies, I have noted during the period of time of the pendency of this action an increasing cautiousness on their part to grant permits for projects of the type and magnitude proposed by the Defendants in this case.

It is apparent, however, that these agencies do not feel constrained to "put the brakes on" developers to the degree that many of us would appreciate. In this regard the recent granting of permit to the developer of Monroe Creek [Tanton] is a good case in point.

Below are two comments from Assistant Attorney Generals, regarding EPA cases they have handled:

The case involves liabilities of a local unit of government and a state agency. ... In my view, the pending litigation has materially affected their attitudes toward environmental issues. Both of the agencies have tightened up their procedures for the handling of contaminating wastes.

Speaking from the agency standpoint, it has made them more careful in documenting their positions and more careful re: initial actions (what is said in a letter or in a meeting). I see no result in so far as D.N.R., Water and Air agencies etc. regarding attitudes on policy and purpose.

The EPA is apparently having an impact in the private sector, too. ${ }^{192}$ Shortly after the defendant pig-farmer won in Crandall $v$. Biergans, the following appeared in an agricultural publication:

There is a tendency for some farmers to think that agricultureespecially the animal industries-won a sweeping victory in the recent trial. This is a dangerous error ... Bill Biergans and his wife received a favorable judgment on their specific, individual operation. Each livestock producer should evaluate his own operations in light of Judge Corkin's opinion to see how he would fare in court.... It is time agriculture took direct, positive action in the area of pollution instead of always being on the defense. We desperately need voluntary guidelines. ... They would strengthen the position of any farmer brought to trial. .. . The time for us to start on them is now!

One last question: If you found yourself in court tomorrow, how would you fare?193

192. See note 224 infra.

193. Michigan Farmer, March 4, 1972. In response to our questionnaire an individual representing agricultural interests replied: ". . a greater awareness has been created 


\section{Questions of Statutory Construction}

\section{A. The EPA as a Source of Substantive Law}

\section{Introduction}

The EPA is not only a procedural statute expanding the scope of standing to sue. $I_{t}$ is also, in and of itself, a source of substantive law. The right created by the EPA is set forth in section 3(1): It is unlawful "to pollute, impair or destroy the air, water or other natural resources or the public trust therein," ${ }^{194}$ unless there is no feasible and prudent alternative that is consistent with the promotion of the public health, safety, and welfare.

Most of the cases litigated thus far do not explore the nature of the substantive right created by the EPA. Some seek to enforce rights created by other statutes, and use the EPA as a source of standing to sue $^{195}$ or as a remedy ${ }^{190}$ on the theory that the EPA incorporates by reference at least those environmental obligations imposed by other statutes.

A number of other cases probably could not have been prosecuted without using the EPA as a source of substantive law, ${ }^{107}$ but the question seems not to have been addressed in those cases. For example, in Payant ${ }^{198}$ the defendant DNR was prepared to accept the assertion that its deer management program ought to comply with the policies of the EPA. It was thus willing to defend its conduct on the environmental merits. ${ }^{199}$

within the agricultural industry toward upgrading and improving handling and disposing of livestock waste." And defense attorney Tim Green advised a Michigan Farm Bureau audience "Farmers who aren't using good animal husbandry practices are in for trouble. ... You should be a bit more conscious of how you run your operations." State Journal (Lansing), Feb. 27, 1972, at G-4, col. 1 .

194. Mich. Comp. LAws ANN. § 691.1203 (Supp. 1972).

195. E.g., WMEAC v. Betz Foundry, Inc.; Alvin E. Bertrand, Inc. v. City of Detroit; MUCC v. Anthony.

196. E.g., the cases initiated by the WCHD and WRC v. Chippewa County.

197. See Appendix I infra.

198. See text accompanying notes 58-64, 113-23 supra.

199. However during preliminary skirmishing DNR lawyers made the usual objection that deer management should be left to the discretion of the DNR, barring arbitrariness and caprice. See text accompanying note 237 infra.

In Muskegon County and Lakeland, the defendants conceded that their proposed sewage treatment facilities ought not pollute, and defended on that ground. The courts never reached the question whether or to what extent the EPA set different or higher standards than the Water Resources Commission Act. Likewise, in Crandall, the "pig odor" case, in which suit was brought both on common-law nuisancc grounds and under the EPA, it was plain that the defendant had some duty not to create noxious odors as a matter of conventional nuisance law. The court, quite reasonably, found that the same evidence which established the absence of nuisance met the affirmative defense requirement of $\S 3(1)$ of the EPA. Mich. CoMr. LAws ANN. 


\section{The Public Service Commission}

The question of the EPA as a source of substantive law arises whenever a defendant asserts that he has no obligation to take environmental considerations into account in the performance of the challenged activity, ${ }^{200}$ and the plaintiff argues to the contrary that the EPA, in and of itself, creates such a duty.

This issue has not yet arisen in pristine form. ${ }^{201}$ The question was, however, addressed, though indirectly, in Michigan Consolidated Gas Co. ${ }^{202}$ There the Gas Company petitioned the Michigan Public Service Commission to authorize it to set up a priority scheme for rationing natural gas; its proposal put the use of gas for control of air pollution problems near the lowest of priorities. Both the Attorney General and the Wayne County Health Department intervened, urging that the use of gas for pollution control should be given a much higher priority. ${ }^{203}$ The Attorney General predicated both his right to intervene and his demand for a higher priority for pollution control explicitly upon the EPA.204

The Commission never denied that it had authority to consider

\$ 691.1203 (Supp. 1972). In such a case, the addition of a count under EPA probably does no more than to shift the burden of justification to the defendant. Compare Blunt v. Apfel, Transcript at 31 (Dec. 10, 1970), in which the distinction between equity's traditional reluctance to enjoin anticipated harm in nuisance cases, and the "likely to pollute" standard of the EPA should have been considered. See note 180 supra and accompanying text; text accompanying note 308 infra.

200. It also arises when the defendant asserts that its obligations are limited by the provisions of another statute. Tanton was such a case, involving the Dam Act. See text accompanying note 233 infra. Ray presented a similar situation involving the Drain Code. See Brief of Defendant in Support of Answer and Motion for an Accelerated Judgment of Dismissal (Feb. 18, 1972). When regulatory agencies have been defendants, it has been argued that the granting of a permit or license by the agency does not violate the EPA since the agency is not causing the pollution. See note 283 infra.

201. See discussion of Roberts in text accompanying notes 65-71 supra, 239-41, 256-60 infra.

202. No. U-3802 (Mich. Pub. Serv. Commn. 1971).

203. Notice of Intervention of Frank J. Kelley, Attorney General, Jan. 8, 1971; Petition for Leave to Intervene by the Wayne County Health Department, Jan. 4, 1971.

204. Intervention is covered in $\S 5(1)$, and the substantive claim in $\S 5(2)$ of the EPA, Mich. CoMp. LAws ANN. §§ 691.1205(1)(2) (Supp. 1972). The Attorney General also predicated his intervention on Attorney General Act § 28, Mrch. Comp. LAws ANN. § 14.28 (1967), which provides that the Attorney General "shall, when requested by the governor ... and may when in his own judgment the interests of the state require it, intervene and appear for the people of this state in any other court or tribunal, in any cause or matter, civil or criminal, in which the people of this state may be a party or interested."

The intervention caused a temporary controversy. Case No. U-3802 Transcript at 16-29 (Jan. 12, 1971) [hereinafter Transcript U-3802]. Intervention was not allowed specifically under the EPA, but objections were withdrawn and intervention was allowed without citation of authority. $I d$. at 29. 
environmental issues, ${ }^{205}$ but seemed to be of the opinion that, while it could take environmental quality into account, it was not required to do so. ${ }^{206}$ The Attorney General argued that under the EPA the Commission was indeed mandated to consider environmental quality and had to give environmental protection a high priority. ${ }^{207}$ As one of the Attorney General's representatives phrased the argument, "the legislature has ... given to this Commission ... other mandates, and one of those mandates is environmental considerations . . . . Yes, there is a mandate to do something about pollution . . . . Pollution questions or considerations should be given equal consideration with industrial uses for which gas is the only feasible fuel." 208

The Commission did not resolve this question explicitly in its order, but it did move pollution control higher on its priority list; and, as one member of the Attorney General's staff later noted, ${ }^{200}$ the intervention served to educate the Commission and to sensitize it to the presence of the EPA as a factor that must be considered when it formulates utility regulation policy.

Subsequent events involving the Public Service Commission seem to confirm this observation. Only a few months later the Commission had before it a proposal for the construction of two separate gas transmission lines within the same general area. ${ }^{210}$ The Attorney General intervened under the EPA on behalf of the DNR, ${ }^{211}$ and objected on environmental grounds to the duplication of pipelines. ${ }^{212}$

205. The Commission cited (Transcript U-3802, supra note 204, at 9) Scenic Fudson Preservation Conference v. FPC, 354 F.2d 608 (2d Cir. 1965), cert. denied 384 U.S. 941 (1966), on appeal from remand, $453 \mathrm{~F} .2 \mathrm{~d} 463$ (2d Cir. 1971), at $354 \mathrm{~F} .2 \mathrm{~d}$ at 620 for the proposition that as a representative of the public, the Federal Power Commission must provide the public with "active and affirmative protection."

The Public Service Commission is given broad general powers under the Public Service Commission Act \& 6, Mrch. Comp. LAws ANn. \& 460.6 (Supp. 1972):

It is vested with power and jurisdiction to regulate all rates ... conditions of service and all other matters pertaining to the formation, operation or direction of such public utilities ... to hear and pass upon all matters pertaining to or necessary or incident to such regulation of all public utilities. . . .

206. Transcript U-3802, supra note 204, at 991-99.

207. Id. at 951-99.

208. Id. at $991-92,994$.

209. Letters from M. Robert Carr, Assistant Attorney General, to Roger Conner, Oct. 4, 1971 \& Oct. 8, 1971, on file with authors.

210. Michigan Consolidated Gas. Co. (No. U-3933) \& Consumers Power Company, (No. U-3935), consolidated, Michigan Public Service Commission, Pipeline Construction Order (Oct. 22, 1971) [hereinafter Pipeline Order].

211. The Boardman River Advisory Council also intervened.

212. Pipeline Order, supra note 210 at 4 . The Attorney General's Petitions to Intervene were filed July $15,1971$. 
Shortly thereafter, the Commission brought about a mutually acceptable settlement that consolidated the pipelines. ${ }^{213}$

These proceedings set a highly important precedent, for they represent the first instance in which the Commission relied on the EPA, ${ }^{214}$ rather than using the broad language in the Public Service Commission Act ${ }^{215}$ to find jurisdiction. The Commission's opinion stated:

On its own initiative and in accordance with the mandate of the Environmental Protection Act of 1970, the Commission has given very careful consideration to the environmental aspects of and alternatives to the proposals of the two Applicants, and the subsequent compromise settlement. Testimony and evidence on the environmental aspects of the routes ... were taken. . . . The compromise settlement has resulted ... in a route which is superior from an environmental standpoint to that originally proposed.216

\section{Commissioner William R. Ralls stated that the case was}

an environmental triumph for the people of Michigan. At one time the two utilities as well as the two oil companies said it was technically and economically impossible to develop a single pipeline system.

But when it became clear that approval of duplicate systems would be difficult to obtain, the producers and utilities got together with members of our staff and the Department of Natural Resources and decided that a single pipeline system could be developed.217

Having moved this far, the Commission took two further steps. It first asked the legislature for authority to order public hearings on the environmental effects of proposed routes for electric power lines, and it simultaneously requested a formal opinion from the Attorney General on whether the Commission already has such authority under the EPA. ${ }^{218}$ Under present practice, the Commission considers only the safety of proposed power lines. Should the Commission be found to have authority to order public hearings-and the Attorney General's office has contended that it does under the EPA $^{210}$ - the routing of power lines in Michigan would be subjected to environmental regulation for the first time.

213. Pipeline Order, supra note 210 at 11.

214. Pipeline Order, supra note 210 at 12. 1972).

215. The Public Service Commission Act § 6, Mrch. Comp. Laws ANn. $\$ 460.6$ (Supp.

216. Id. at 11 .

217. Detroit Free Press, Oct. 23, 1971, at 3-A, col. 1.

218. Id., Jan. 21, 1971, at 3-A, col. 1 .

219. Id. 
Notably, the steps taken by the Commission have been motivated not only by the Attorney General's initiative in the two cases discussed above, but also by another precedent that was initiated under the EPA, Beach v. Detroit Edison Co.

\section{Eminent Domain}

Beach arose out of a condemnation petition filed by Detroit Edison to acquire land in Washtenaw County for a proposed highvoltage transmission line. ${ }^{220}$ The affected landowners responded by bringing suit under the EPA to enjoin the condemnation on the grounds that the proposed route would be environmentally detrimental and that Detroit Edison had not adequately considered less harmful alternatives, such as use of existing utility corridors. The statute granting utilities the right to eminent domain does require a showing of "necessity" by the condemner, ${ }^{221}$ but that requirement has traditionally been ignored as a practical matter; most condemnation cases have involved little more than the question of how much money the landowner would receive.222

Beach was brought in the circuit court to enjoin or control the condemnation proceeding in the probate court. It raised for the first time the question of how the EPA's enactment affects condemnations by utilities. The following excerpt from the circuit court hearing provides a partial answer:

The Court: May I suggest for counsels' consideration a possibility and that is that $I$ issue to the Probate Court a mandamus, or a writ of superintending control instructing the Probate Court that in conducting the hearing on necessity in this action they are to establish standards for compliance with the Environmental Protection Act ... that I retain jurisdiction for the purpose of reviewing any finding of necessity which might be made in the Probate Court and under section $2 \mathrm{~b}$ of the Environmental Protection Act to review the standards, or standard there established, to see whether such is or is not efficient.

... The purpose of that is as follows: This allows the Probate Court

220. Petition of Detroit Edison Co. to Condemn a Right-of-Way, No. 58.068 (P. Ct., Washtenaw County).

221. Mich. Comp. LAws ANN. 486.251-.252, -.254 (1967).

222. See Detroit Edison Co. v. Matuja, 365 Mich. 35, 112 N.W.2d 109 (1961). The situation is changing, but slowly. See Thompson v. Fugate, 452 F.2d 57 (4th Cir. 1971); New Windsor v. Ronan, 329 F. Supp. 1286 (S.D.N.Y. 1971); Seadale Indus. v. Florida Power \& Light Co., 232 S.2d 46 (Fla. 1971); Texas Eastern Transmission Co. v. Wildlife Preserve, 48 N.J 26I, 225 A.2d 130 (1966), 49 N.J. 403, 230 A.2d 505 (1967), discussed in Sax, The Search for Environmental Quality, in The Environmental CRisis 99 (H. Helfrich, Jr., ed. 1970); Foster v. DNR, No. 9906-C (Cir. Ct., Ingham County, May 31, 1972); Note, Eminent Domain and the Environment, 56 CORNELr L. REv, 651,659 (1971). 
to discharge the primary duty of finding project necessity and it does not bar it from proceeding to make a determination of site necessity so long as the Probate Court has established or found satisfactory standards of compliance with the Environmental Protection Act, yet it reserves to this court the power to review those standards in the present action and under that Act, and to overturn, if necessary, the standards approved and specified by this Court, and if necessary to direct another re-hearing on at least site necessity, should that be indicated. That leaves this Court in its proper position of reviewing the actions of the Probate Court, yet raises clearly the issue of whether or not the Probate Court can properly follow this Court's order to comply with the standard provisions of the Environmental Protection Act, thus raising a proper question of law. ${ }^{223}$

The attorneys were unable to agree on a precise wording for the writ, and the dispute has since gone forward in the probate court. 224

\section{Roberts $v$. Michigan}

Roberts v. Michigan ${ }^{225}$ indicates the limits of the EPA as a source of new duties for administrative agencies. It will be recalled that the plaintiff sued the Highway Department and Secretary of State for failing to deal with automotive air pollution. While, as we have seen in connection with our discussion of the Public Service Commission, ${ }^{226}$ the EPA can be read into a regulatory agency's mandate, the question still remains: whether the particular environmental obligations the plaintiff seeks to impose should be made the responsibility of the agency he has sued.

The Highway Department does not have a general mandate to

223. Beach v. Detroit Edison Co., Transcript at 2-3 (Sept. 16, 1971).

224. The three-member probate court commission found the project "necessary," but found no necessity for the taking of certain parcels of land. Ann Arbor News, April 27, 1972, at 3, col. 6; id., May 5, 1972, at 11, col. 3; id., May 23, 1972, at 3, col. 4. A final decision must await the determination of the probate judge and subsequent proceedings in the circuit court. Meanwhile:

The Detroit Edison Co., concerned by public crticism over its condemnation of private property, initiated a unique policy ... of holding public hearings on

routes it selects for electric transmission lines.

....

Edison's [d]ecision to hold the hearings came . . . after public attention brought by a number of landowners who . . challenged in court the company's right to condemn private property.

Although lower court decisions in that case [Beach v. Detroit Edison Co.] have so far supported Edison, the company has also come under the review of the Public Service Commission, which for the first time is considering making an attempt to control the location of power lines and power plants.

Detroit Free Press, May 26, 1972, at 7-G, col. 1.

225. See text accompanying notes 65-71 supra, 239-41, 256-60 infra.

226. See text accompanying notes 200-19 supra. 
regulate traffic on the highway, but is primarily responsible for the highways themselves; ${ }^{227}$ while the Secretary of State is authorized to enforce statutory standards governing the condition of vehicles, 228 it is the Air Pollution Control Commission that is responsible for "[p]romulgat[ing] rules and regulations for controlling or prohibiting air pollution ..."229-the relief that the plaintiff in Roberts was seeking. Even though Roberts could have demonstrated that there existed some nexus between the agencies he sued and the relief he sought, he would still have had to convince the court that the legislature had not invested some other agency-in this instance the Air Pollution Control Commission-with primary authority over the subject matter of the suit. ${ }^{230}$

\section{Relation of the EPA to Other Statutes}

Whenever a plaintiff suing under the EPA challenges a defendant who has complied with the provisions of another statute that also governs his conduct, two difficult questions arise: Does the EPA supplement and amend the other statute? If it does not, and if the statutes are viewed as conflicting, which is to prevail?

Ordinarily, no substantive conflict will arise. The broad antipollution provisions of the Water Resources Act, for example, will generally serve as ample basis for suits filed under the EPA. ${ }^{231}$ In such cases the courts can, and will view the EPA as an alternate route for implementing the State's antipollution policy. ${ }^{232}$

In other instances, while the substantive environmental policy of another statute may be adequate, it may be necessary to allege that the EPA supplements the existing law by making mandatory

227. State Highway Department Organization Act $\S 7$, MrGH. CoMr. LAws ANN. \$ 247.801 (1967) as amended (Supp. 1972), General Highway Law ch. 5 \& b, Mich. CoMP. LAWS ANN. $\$ 225.2(\mathrm{~b})$ (1967).

228. Vehicle Code $\S \S 204,707$ (a), Micr. CoMp. LAws ANN. $\S \S 257.204,-.707$ (a) (1967) as amended (Supp. 1972).

229. Air Pollution Act $\S$ 2(c), 5(a), Mich. CoMr. LAwS ANN. $\S \S 336.12$ (c), -.15 (c) (1967) as amended (Supp. 1972).

230. This is not to say that there will not at times be more than one agency with authority over various elements of an environmental problem. See, e.g., Ray v. Raynowsky, Transcript at 18-19 (Nov. 23, 1971), regarding the relative responsibilities of the Drain Commissioners and the WRC. But whenever there is an agency that has an obvious relationship to the problem, and which can do the job adequately, there is no need to impose responsibility upon another agency whose regular functions are quite unrelated to the issue plaintiff wishes to raise. See Upper Pecos Assn. v. Stans, 452 F.2d 1233 (10th Cir. 1972). See note 70 supra.

231. This is not always the case. See discussion of Marble Chain of Lakes v. WRC in note 71 supra.

232. See discussion of primary jurisdiction, especially Lakeland and Chippewa County, in text accompanying notes 72-101 supra. 
what would otherwise be discretionary. For example, in Tanton, in which the plaintiff challenged the DNR's granting of a permit for the construction of a dam, the defendant Department relied upon section $2 \mathrm{~b}$ of the Dam Act, which states:

A permit may be issued if, in the opinion of the director . . . the presence of an impoundment will not have a significant adverse effect on fish, wildlife or recreational values in the watershed or infringe on the public rights in the waters of the state. ${ }^{233}$

In cases like Tanton-where the Dam Act amendment became effective subsequent to the enactment of the EPA-the court must read the statutes compatibly if possible. In Tanton, for example, harmonizing the provisions of the EPA and the Dam Act would seem to present no great difficulty. The principal purposes of the EPA were to remove free-wheeling administrative discretion and to assure that regulatory agency decisions were environmentally defensible on their merits. ${ }^{234}$ There is no reason to believe that the recent Dam Act amendment was intended to amend the EPA, and it is quite easy to read the two statutes as conforming with each other. Thus the language of the Dam Act emphasized above can be interpreted -in conformity to the EPA-to mean that a permit may be issued when the director believes there is no threat of harm and when that opinion is warranted by the facts of the case. ${ }^{235}$ Such interpretations

233. Mich. Comp. LAws ANn. \& 281.132b (Supp. 1971) (emphasis added).

234. Sax Testimony supra note 47; Press Release of Rep. Thomas Anderson (sponsor of H.B. 3055) at 1, Jan. 16, 1970, on file with author; Remarks of Sen. Basil Brown (debate on H.B. 3055, Michigan Senate), June 25, 1970, transcript on file with author; Allbaugh, Public Overwhelmingly Supports Antipollution Bill at Hearing Here, Grand Rapids Press, Feb. 27, 1970, at I-B, col. 3.

235. This interpretation is supported by two other legal mandates under which the DNR operates. The DNR's enabling legislation, MICH. CoMP. LAws ANN. § 299.3 (1967) as amended (Supp. 1972), provides:

The Department of Conservation shall protect and conserve the natural resources of the state of Michigan; ... prevent and guard against the pollution of lakes and streams within the state, and enforce all laws provided for that purpose with all authority granted by law, and foster and encourage the protecting and propagation of game and fish.

See also GOvernor's Execurrve Direcrive 1971-10, Sept. 30, 1971, which reads in pertinent part:

To: All Department Heads

From: Governor William G. Milliken

Subject: Environmental Impact Review

I believe it is the responsibility of State government to lead the way in all aspects of environmental quality protection. Major state activities which affect the environment need to be carefully scrutinized, so that the changes brought about in land, water or air use are consistent with overall State environmental policy objectives.

I am directing that each agency of State government review all major activities within their jurisdiction to determine their effects on the environment. Such review must include the following:

1. The probable impact of the action on the environment; this includes the 
have been made of similar language in other environmental cases. ${ }^{230}$

A similar question arose in Payant. In a pre-trial motion for summary judgment, the Attorney General argued that the court had no authority over the Department's game management program other than that necessary to correct abuse of discretion, and cited as authority for this proposition a 1925 statute that gave the Conservation Commission its "power to regulate the taking ... of all game or fur bearing animals ... whenever in the opinion of said commission ... it becomes necessary to assist in the increased or better protection of such . . . animals." ${ }^{237}$ The court's response, denying the DNR's motion, should set a significant precedent for interpreting the EPA:

$[W]$ e do not believe, especially in the light of the Environmental Protection Act, that arbitrary, unfettered discretion and unchallengeable power is vested in the Department and Commission. If it can be shown that the regulations permitting the taking of antlerless deer are likely to impair or destroy a natural resource, the courts may intervene. It is conceded that plaintiff has a standing to bring the action and the Act clearly authorizes suits against such bodies as the Department and Commission. ${ }^{238}$

In addition to the methods adopted in Tanton and in Payant for reconciling the provisions of potentially conflicting statutes, there is one other interpretive technique courts could use to preserve the EPA's vitality. If necessary, provisions in existing statutes could be

impact on human life or other ecological systems such as wildlife, fish and aquatic life; or on air, water or land resources;

2. Probable adverse environmental effects of the action which cannot be avoided (such as air or water pollution, damage to life systems, urban congestion, threats to health or other adverse effects on human life);

3. Evaluation of alternatives to the proposed action that might avoid some or all of the environmental effects indicated above. This should include a full explanation of the reasons why the agency decided to pursue the action in its contemplated form rather than an alternative course of action;

4. The possible modifications to the project which would eliminate or minimize adverse environmental effects, including a discussion of the additional costs in-

volved in such modifications. ... .

236. For instance, in Environmental Defense Fund, Inc. v. Hardin, 428 F.2d 1093, 1097-98 (D.C. Cir. 1970), the court stated that

[r]espondents . . . argu[e] that the decision to suspend the registration . . . is committed by statute to unreviewable administrative discretion ..... That evidence cannot be found in the mere fact that a statute is drafted in permissive rather than mandatory terms. Although [the statute] provides that the Secretary "may" suspend the registration of an economic poison that creates an imminent hazard to the public, we conclude that his decision is not thereby placed beyond judicial scrutiny.

See Barlow v. Collins, 397 U.S. 159, 165-66 (1970); Citizens To Preserve Overton Park v. Volpe, 401 U.S. 402 (1971).

237. Conservation-Fish \& Game-Regulatory Powers \& 1, Mrch. Comp. Laws ANN. $\S 300.1$ (1967). For a similar argument, See Ray Transcript, supra note 161, at 9-11.

238. Payant v. DNR, Opinion of Judges Brown, Davidson \& Munro at 2-3 (Sept. 4, 1971) (denying defendant's motion for summary judgment). 
viewed as exemplary rather than exclusive, and no conflict could therefore be said to exist between those statutes and the EPA. For example, in Roberts, the judge noted that the Vehicle Code requires every motor vehicle to "be so equipped and adjusted to prevent the escape of excessive fumes and smoke." ${ }^{339} \mathrm{Had}$ the case gone to trial, and had the plaintiff proved that other emissions besides excessive fumes and smoke caused pollution problems, Judge Warren could quite comfortably have treated the EPA and the Vehicle Code as complementary. Instead, inexplicably, he viewed the prohibition of fumes and smoke as the furthest that the legislature had gone in regulating automobile air pollution, and suggested that if he were to find and remedy pollution from other sources, he would, in effect, be repealing a legislative limitation. ${ }^{240}$ Not only is this interpretation of the Vehicle Gode forced, but if accepted, it would create a conflict between the Vehicle Code and the much broader standards of the Air Pollution Act. ${ }^{211}$

Thus far no case has involved an explicit conflict between the provisions and policies of the EPA and those of any other statute. ${ }^{242}$ Indeed, because the EPA is a direct implementation of a constitutional provision, ${ }^{243}$ it is unlikely that the EPA will, upon examination, be found in conflict with policies of other statutes; and it was certainly the understanding of the legislature that the EPA stated the general environmental policy of the state.

Naturally, it is always open to the legislature to enact an explicit exception to the EPA. Just as they have enacted the law, so is it within their authority to modify it; but one ought to be cautious in reading implied modifications into statutes of general application such as the EPA. Moreover, when attempting to determine legislative policy, it is important to compare the present status of a 1970 law, like the

239. Roberts v. Michigan, Opinion of Judge Warren at 3 (May 4, 1971), quoting Vehicle Code $\S 707(\mathrm{~b})$, Mich. Comp. LAws ANN. \$ 257.707(b) (1967).

240. Id. at 3-4.

241. See note 229 supra.

242. At present, only one case, Leelanau, which involves a proposed transfer of state park lands to the federal government, may raise a specific conflict problem. Should the legislature enact a law explicitly authorizing the transfer of the land and expressly addressing the environmental issues involved in the transfer, it would be diffcult to argue that the transfer violated the EPA.

243. Mrcr. Consr. art. IV, \& 52 (1963), set out in note 6 supra. To be sure, at some point there is a constitutional question concerning the preservation of the public trust, which even the legislature cannot violate; see Sax, The Public Trust Doctrine in Natural Resource Law: Effective Judicial Intervention, 68 MICH. L. REv. 471, 489-92 (1970). Moreover, even when an express legislative authorization exists, it must be examined closely, for it may well grant authority that is subject to compliance with other laws. See, e.g., D.C. Fedn. of Civic Assns. v. Volpe, 434 F.2d 436, 443-44 (D.C. Cir. 1970). 
EPA, with that of some much older statute that is asserted to undercut the EPA's environmental mandate.

To the extent that judges may in future cases find conflict between the EPA and explicit, detailed provisions in other germane statutes, they must, of course, apply the usual standards of statutory construction for bringing diverse legislative pronouncements into harmony. When the legislature has incorporated an exacting or quantitative standard into a law subsequent to the EPA, the courts should ordinarily view that standard as governing. If, for example, the legislature has declared explicitly that certain areas shall be roadless wilderness, certainly one would expect a court to view that determination as setting the environmental standard, and the EPA would have to be read in conformity with this more specific statute. Similarly, if the legislature has decided that there shall be so many parts per million of dissolved oxygen in a given stream, or that certain industries shall have a limited number of years to clean up pollution, the EPA would have to conform to those explicit mandates. It should be noted, however, that the preceding speaks only to legislatively set standards, not to those promulgated by administrative agencies; for if anything is clear about the EPA, it is that the law was designed to reduce the range of discretion traditionally given to regulatory agencies and to enable citizens to challenge standards established by those agencies.

Surely, difficult borderline cases will arise, and courts may at times have to struggle to reconcile statutes that look in different directions; but this task is inherent in the very nature of the judiciary's traditional job of statutory construction. ${ }^{244}$ Thus far the courts have not had to face this problem in the litigated cases.

\section{B. Constitutionality of the EPA}

The only provision of the EPA that has raised a constitutional question is section 2, which provides:

(2) In granting relief provided by subsection (1) where there is involved a standard for pollution or for an anti-pollution device or procedure, fixed by rule or otherwise, by an instrumentality or agency of the state or a political subdivision thereof, the court may:

244. Some recent cases under the National Environmental Policy Act, 42 U.S.C. \& 4921, 4331-35, 4341-47 (1970), illustrate the problem. See National Helium Corp. v. Morton 455 F.2d 650 (10th Cir. 1971); Ely v. Velde, 451 F.2d 1130 (4th Cir. 1971). 
(a) Determine the validity, applicability and reasonableness of the standard.

(b) When a court finds a standard to be deficient, direct the adoption of a standard approved and specified by the court. ${ }^{245}$

Although the main purpose of this Article is to provide a description of cases litigated under the EPA-not to set out a legal analysis of the statute-in light of the controversy that has developed over section 2 in the litigated cases, a few general observations are warranted.

Section 2 seems to have created the impression in some quarters that the courts are empowered, because of the EPA, to re-examine legislatively set standards and to repeal and replace those found to be deficient. Clearly, the section has no such purpose. Section 2 is not directed to standards fixed by the legislature, but to those set by regulatory agencies and political subdivisions. If the legislature sets a specific standard that is inconsistent with the EPA, the courts must comply with that standard. The EPA, after all, is not a constitution.

At the same time, the EPA itself does set an environmental policy; and for the courts to implement that policy-against an agency's rule or regulation-is not to usurp legislative prerogatives, but to enforce them. Although its provisions are phrased in broad terms, the EPA is nonetheless a statute, superior to the explicit decisions and rules of regulatory agencies and local governments.

Moreover, there is no constitutional reason why the legislature, which granted authority to the courts by enacting the EPA, may not limit the ambit of agency discretion and require every agency to meet the legal standard of section 3(1), leaving the enforcement of that standard to the court. Indeed, the recent decision of the Supreme Court in Citizens To Preserve Overton Park v. Volpe ${ }^{246}$ confirms this point. In that case, the Court had to determine the validity of a statute in which Congress, using language identical to that in section 3 of the EPA, ${ }^{247}$ had commanded that highways should not be built through parklands unless "there is no feasible and prudent alternative to the use of such land. ..."248 The government argued that the location of highways had been left to the discretion of the Secretary of Transportation and that the court could not interfere with his determination of whether there were feasible and prudent alterna-

245. Mich. Comp. Laws ANN. \$ 691.1202 (Supp. 1972).

246. 401 U.S. 402 (1971), on remand, 335 F. Supp. 874 (W.D. Tenn. 1972).

247. Mich. Comp. Laws ANN. § 691.1203 (Supp. 1972).

248. The Department of Transportation Act of 1966, 49 U.S.C. $\S 1653(f)$ (1970). 
tives. The Court flatly rejected this interpretation, stating, "there is law to apply"; 248 that is, the Court was of the opinion that the regulatory official's determination must now be tested against his compliance with a legal standard relating to alternatives, and, of course, the meaning and scope of that legal standard is a question for the courts to decide. ${ }^{250}$

In light of these preliminary comments, it would be appropriate to consider the three cases in which constitutional questions have been addressed by the courts: Roberts, Crandall, and Lakeland.

Crandall is at once the most enlightening and puzzling of cases. Although Crandall was originally brought as a common-law nuisance action by neighbors of an odorous hog-finishing barn, a claim was subsequently added under the EPA.

After hearing extensive testimony at the trial, the Crandall court held that the defendants were carrying on their business "in a careful and husbandlike manner and us[ing] such odor control products as are . . . available. . . ."251 It thus concluded that "on balance the equities are in favor of defendants and they are not maintaining a nuisance." 252 As for the EPA claim, the court stated:

as the Court interprets Sec. 3 of the Act the legislature is in effect saying that some balance has to be maintained between absolutely no pollution and the carrying on of activities necessary to human existence. The raising of livestock . . . is a lawful and necessary occupation that of necessity will result in . . . odor. It would be the opinion of the Court that if the livestock operation is carried on in an area zoned for that purpose in a generally accepted manner, and that the operation is carefully carried on so that waste products are handled with reasonable efficiency and dispatch so that the odor entering the atmosphere is held to a practical minimum, it could very well be said that a defendant has established an affirmative defense "that there is no feasible and prudent alternative to defendant's conduct and that such conduct is consistent with the promotion of the public health, safety and welfare."253

Had the judge said no more than this, it would no doubt be generally

249. 401 U.S. at 413 .

250. The Overton Park case was governed by the federal Administrative Procedure Act, 5 U.S.G. \& 706 (1970), which provides a more limited degree of judicial review than the EPA. Nonetheless, the Court made it clear that when a legislature limits agency discretion and substitutes a legal standard, it is the duty of courts to enforce that legal standard by the scope of judicial review that they have been authorized to apply. Thus Overton Park addresses questions concerning the judicial function that are similar to the constitutional questions raised under the EPA.

251. Crandall v. Biergans, Opinion of Judge Corkin at 6 (Feb. 14, 1972).

252. $I d$.

253. Id. at 11-12. 
agreed that he had responded quite appropriately to the case before him. He had heard the testimony, evaluated it, and found that the defendants' conduct was in compliance with the mandate of the EPA. As the judge quite correctly pointed out, the EPA demands that "some balance has to be maintained. . .." So long as that balance gives important weight to environmental quality, and the court considers the availability of alternatives and the necessity of defendant's conduct, the policy of the EPA is vindicated.

However, for reasons that are not clear, ${ }^{254}$ Judge Corkin seemed to believe that the EPA required something more of him, for he proceeded to say:

Here the Court, of necessity, must determine that standards relating to the raising and maintaining of livestock are deficient because none exist. It is being asked to create standards, direct their adoption and proceed to enforcement. The Court would regard this as making law and thus an unconstitutional delegation of legislative power so far as the raising of livestock is concerned. The Court does not think the Environmental Protection Act, as it now stands, can serve as a basis for any relief to plaintiffs. ${ }^{255}$

The decision, as a whole, and especially that part reprinted above, suggests that the court did indeed develop specific standards for the case where none previously existed in legislation or administrative rules; and that the judge enforced those standards by finding that the defendants had complied with the policy of the EPA, a policy that is largely coextensive with the law of nuisance as he applied it in this case. Thus his own decision seems to obviate the constitutional concerns he expressed. The case may be counted as a successful application of the EPA.

In Roberts, Judge Warren, after observing that the Vehicle Code prohibited "excessive smoke and fumes," vision as indicating that the legislature was unwilling to accept any regulation beyond that of "excessive smoke and fumes." Thus he refused to read the EPA as authorizing him to take evidence on, and to control, other automobile exhaust pollution problems. With that rather peculiar interpretation behind him, he continued:

Quite clearly the legislature did adopt standards, and quite clearly those standards are deficient.

This gives rise to the first question which is this: "Just who is it

254. The plaintiff seemed to be urging the judge to write a set of general regulations for agriculture, rather than merely apply appropriate standards to the instant case. Crandall v. Biergans, Tape of trial (comments of plaintiff's attorney).

255. Crandall Opinion, supra note 251 , at 13.

256. See note 228 supra. 
that this Court will "direct" to adopt adequate standards? Could it be any body other than the legislature? ... This Court is disinclined to attempt to "direct" the legislative branch of government. Courts should resist the temptation to legislate and to substitute themselves and their judgment for that of the duly elected representatives of the general public.

...

"Legislative power" may not be delegated. . . . This Court concludes that it is being called upon to make law. ... .

For the foregoing reasons the Court concludes that this Act, so far as it pertains to pollution arising from the operation of motor vehicles is unconstitutional. ${ }^{257}$

What Judge Warren apparently failed to realize is that the legislature is not required to spell out precisely what courts must do. Rather, it may enunciate the general policy and leave the details to be filled in by the judiciary on a case-by-case basis. It would clearly be anomalous to find the EPA unconstitutionally vague ${ }^{258}$ when other laws-such as the federal antitrust laws ${ }^{260}$ - which are even less detailed than the EPA-have been upheld by the courts for years. Furthermore, it would seem odd for the courts, which have for centuries evolved and applied common-law rights such as nuisance without statutory help, to balk at developing a similar body of law for environmental regulation, especially when they are under an explicit mandate from the legislature to do so. ${ }^{200}$

In Lakeland, the court, after a full trial, found that the effluent from defendant's treatment plant was polluting waters below the point of discharge and that the effluent from the proposed enlargement of the plant, even if in conformity with effluent standards set by the Water Resources Commission, would constitute pollution. ${ }^{201}$ The court held that the plaintiffs had made a prima facie case and

that the affirmative defense raised by the defendants herein of there being no feasible and prudent alternative to their conduct [had] not been borne out by defendant's proofs. Defendants merely recited, through their witnesses, that there was no reasonable and feasible

257. Roberts Opinion, supra note 239, at 4-5.

258. See Note, The Constitutional Question: Vagueness and Delegation of Powers, 4 U. Mich. J. L. REF. 397 (1970). See also Annot., 32 A.L.R.3d 215 (1970).

259. See Appalachian Coals, Inc. v. United States, 288 U.S. 344, 359.60 (1933). See also United States v. Republic Steel Corp., 362 U.S. 482, 492 (1960) (vagueness challenge to Rivers and Harbors Act of 1899).

260 See State ex rel. Board of Health v. Diamond Mills Paper Co., 63 N.J. Eq. 111, 115-16 (1902); Air Commn. v. Coated Materials, 1 BNA Env. Rep. Cases 1444, 1447 (Ct. C.P., Dauphin County, Pa. 1970).

261. Lakeland Opinion of Feb. 29, 1972, supra note 95, at 180. 
alternative to their actions and did not support such recitations with facts other than alluding to economic considerations. ${ }^{262}$

Judge Mahinske then noted that this suit was not brought to review the standards set by the Water Resources Commission, but was instead an original EPA action against the defendants for pollution in which the defense was largely predicated on compliance with those standards. ${ }^{263}$ Under the EPA, his opinion quite properly indicated, mere compliance with such standards is not a defense; plaintiffs may challenge administratively set standards as inadequate to prevent pollution prohibited by the EPA. ${ }^{264}$ In this respect, he also found that defendant's conduct constituted a nuisance and violated the plaintiffs' riparian rights. ${ }^{265}$

Having found that the defendant's conduct violated the EPA and that the WRC's administrative standards, which defendant had relied on, were insufficient to meet the demands of the EPA, Judge Mahinske next dealt with the defendant's contention that the EPA was unconstitutional:

Defendant, in its Brief, relies heavily on the opinion of Judge Warren, . . . in the matter of Roberts v. State of Michigan. ... This Court is of the opinion that it is not controlled by the opinion set out in Roberts by the learned Ingham County Circuit Court Judge and further finds that any dispute between circuits must be resolved by a higher tribunal.

This Court does not believe [the EPA] is unconstitutional by virtue of it having contained therein a prohibited delegation of powers. Said Act simply states that when a Court finds a standard to be unreasonable or deficient the Court may set an acceptable standard which the Court may enforce directly or order the agency involved to enforce such standard.266

\section{Intervention in EPA Cases}

The EPA provision on intervention is not as clear as it might be. The statute provides:

Whenever administrative licensing or other proceedings, and judicial review thereof are available by law, the agency or the court may permit ... any person ... to intervene as a party plaintiff. ... ${ }^{267}$

262. Id. at 18.

263. Id. at 19.

264. Id. at 21-23.

265. The Water Resources Commission Act, $\$ \S 6(c) 12,12(a)$, itself preserves other remedies. Mich. Comp. LAws ANN. \& 323.6(c) (Supp. 1972), 323.12, -.12(a) (1967).

266. Lakeland Opinion of Feb. 29, 1972, supra note 95, at 19-20.

267. EPA \& 5(1), Mich. CoMp. LAws ANN. § 691.1205 (Supp. 1972). For a discussion of the Attorney General's intervention in Public Service Commission Proceedings, see text accompanying notes 200-24 supra. 
Plainly, the draftsmen of this provision did not have in mind inter. ventions in suits originally filed under the EPA. The purpose of the provision was to "equalize" the law by permitting anyone who could have filed an original suit under the EPA to intervene in a proceeding in which the same type of issues might arise-that is, in an administrative proceeding or in a court case brought to review an administrative decision.

It was not thought necessary to specify a right to intervene directly in a suit filed under the EPA for the simple reason that anyone who might wish to intervene could file an original suit himself under the broad standing provision of the EPA. Indeed, when the question of intervention by an environmental group arose in Tanton, the judge responded to the defendant's opposition by saying "You want them to file a separate action? I'll just consolidate them." ${ }^{208} \mathrm{He}$ then granted the motion to intervene, under the rules governing permissive intervention. ${ }^{269}$

While it seems wasteful to deny intervention to an applicant who can simply file a new complaint on his own and then seek consolidation, at least one court has nevertheless held that the right to intervene is permissive. ${ }^{270}$ In Wayne County Health Department $v$.

268. Hearing on Motion To Intervene and for a Change of Venue, Jan. 14, 1971 (from authors' notes taken at pre-hearing conference in Judge Reisig's chambers). The question arose again in Charlevoix when EMEAC petitioned to intervene. The motion was granted (authors' trial notes).

269. MICH. CT. (GEN.) R. 209.2(2) (1969): "Upon timely application anyone may be permitted to intervene in an action ... when an applicant's claim or defense and the main action have a question of law or fact in common."

270. See MICr. CT. (GEN.) R. 209.1(1) (1969). The legislative history of the intervention provision provides a fascinating sidelight on the dangers of divining legislative intent. The original bill, introduced April 1, 1969, exactly as drafted by Joseph L. Sax, provided:

Sec. 5(1) In such administrative, licensing or other proceedings, and in a judicial review thereof made available by law, the attorney general ... or a citizen may intervene as a party on the filing of a verified pleading asserting that the proceeding or action for judicial review involves conduct ... . which may have the effect of impairing, polluting. ...

This provision, permitting intervention as a right, was not challenged. The Governor's legal adviser objected to numerous provisions of the bill but approved of the intervention provision. See Memo from the Governor's legal adviser to Governor Milliken, Jan. 26, 1970.

On March 25, 1970, the House Committee reported out a substitute bill which continued to include the language on intervention of section $5(1)$ cited above, and in. cluded in the proposed section 6 additional intervention-as-of-right language recommended by the Governor's legal adviser.

It was not until the second substitute version of the bill, passed by the House of Representatives on April 21, 1970, that the language "the agency or the court may permit" intervention first appeared. The only known source for this change is a pencilled modification adding this language on a copy marked up by Joseph L. Sax, which was prepared with a number of suggestions sent by Sax to the sponsor of the bill (Rep. Thomas Anderson) to be added to the second substitute bill. Sax has no recollection of why the change was made or what provoked it, nor does he recall having 
Chrysler Corp., a case involving air pollution at a Chrysler foundry, intervention was sought by both the Attorney General and a group of several hundred residents of the neighborhood. ${ }^{271}$ No objection was interposed to the Attorney General's motion, ${ }^{272}$ but Chrysler opposed the private intervention, noting that the EPA gave no unconditional $^{273}$ right to intervene. Chrysler also contended that the parties seeking intervention were splitting their cause of action because they had a nuisance case for damages pending against Chrysler; they were already adequately represented by the WCHD; and the suit would be unduly delayed because complex negotiations between Chrysler and the WCHD had been in progress for several months. ${ }^{274}$

At first, the judge granted the citizens permissive intervention, ${ }^{275}$ and disposed of fears of delay by emphasizing that his strong management of the case would preclude any such problems. He added:

[t] his whole problem of pollution-environmental problems, we now learn is affecting health, homes, property. . . . Who else has a greater right, as a class, ... to be represented? ... One of the great sins of our time, I think, is that there is a breakdown of communication between people in public life and people in quasi-public life, as I would refer to the Chrysler Corporation. . . This constant communication and understanding and exchange is most important, and if it has to be done in the media of a court, then I shall be the first to see that it is done.278

Five months later, however, Chrysler, Wayne County, and the Attorney General were all in agreement on a proposed order that set out responsibilities for Chrysler and continued the court's jurisdiction to assure compliance with the order. But the intervening citizens would not agree to the order. They wanted the judge to hear testimony and Chrysler to admit that it had been polluting. ${ }^{277}$ The

any intention of making intervention more difficult. In any event the new permissive language, replacing the previous intervention provision, stayed in the bill.

A detailed scrutiny of all the voluminous correspondence, drafts, reports and newspaper articles on the bill, gathered from the files of all those who were active in the bill's enactment, including legislators, reveals that there was never any discussion or consideration whatsoever of this language.

271. Motion of Frank J. Kelley, Attorney General, to Intervene as a Party Plaintiff, May 11, 1971; Motion of Rev. Joseph C. Nosal and 327 Others To Intervene as Parties Plaintiff, March 23, 1971. See text accompanying notes $38-42$ supra.

272. See note 204 supra.

273. Memorandum of Law of Defendant in Opposition to Motion To Intervene at 6, WCHD v. Chrysler Corp. See Transcript at 6 (April 2, 1971); Transcript at 45, 58-64 (Sept. 16, 1971).

274. Memorandum supra note 273 , at 1-5.

275. Chrysler Transcript of April 2, 1971, supra note 273, at 8.

276. Id. at 5.

277. Chrysler Transcript of Sept. 16, 1971, supra note 273, at 56 . 
intervening plaintiffs had a special interest in using this suit to advance their interest in the separate, pending damage action.

The situation created a dilemma for the judge. He wanted to settle the case, and he was obviously proud of the consent order he had obtained from three of the parties, but he doubted the legality of his signing the order without the consent of all of the parties.278

The solution the judge found was to dissolve the order granting intervention. But to do this, he had to be satisfied that the private parties were permissive intervenors and not intervenors of right. The judge thereupon ruled that the EPA did not give a right of intervention, that the intervention was creating delay, and that the intervenors' rights would be adequately protected in their damage action. He then set aside the order permitting intervention and granted the private parties the status of amici curiae. ${ }^{270}$

\section{Jurisdiction and Venue}

In addressing the issues of jurisdiction and venue, section 2(1) of the statute simply provides that a plaintiff "may maintain an action in the circuit court having jurisdiction where the alleged violation occurred or is likely to occur."280

In Tanton, ${ }^{281}$ suit was brought against both a developer and against the DNR, which had issued the permit authorizing the dam. Although the proposed project itself was in Charlevoix County, the plaintiff decided to sue in Ingham County, where the DNR was located and where the permit had been issued. Thus three issues

278. The judge noted, id. at 57:

I am still fearful that if this case goes to trial now (you will not go to trial for some time) and in the meantime nothing is being done, and the people out there wait ... the possibility is imminent and great that if $I$ enter an order it may be appealed and that is going to take years.

What I am trying to do is get some Court order controlling the Chrysler Corpo. ration with respect to these problems that not only has some finality, but still gives this Court a continuing jurisdiction over the project. ... It requires Chrysler to do certain things and if they don't comply, on forty-eight hours notice they are back in court for contempt of the Court's judgment.

279. Id. at 44-46, 59.64. The judicial order disallowing the intervention of the private plaintiffs has been appealed, WCHD v. Chrysler Corp., appeal docketed No. 1219 Mich. Ct. App. In Lakeland, a local community intervened as a defendant. In Payant, the MUCG intervened, without protest, as an amicus curiae. In Betz Foundry, the plaintiff was denied the right to intervene in pending administrative proceedings and has appealed that denial (see note 94 supra); and in Chippewa County, the State Highway Department was joined as a third party defendant.

280. MICH. CoMP. LAwS ANN. § 691.1201 (Supp. 1972). The issue of removal from state to federal courts is not discussed in the text. WCHD v. National Stecl Corp. was removed to the federal court. Judge DeMascio remanded to the Wayne County circuit court. WCHD v. National Steel Corp., Order of Remand (Nov. 11, 1971). See McPhail v. Corps of Engineers, note 13 supra.

281. See text accompanying notes 130-145, 233-36 supra. 
had to be decided by the Tanton court. First, was the issuance of the permit (which does not itself create pollution) a "violation" of the Act? Even if it was, does the EPA lay venue in the place where the violation of the Act-the issuance of the permit-occurs, as well as where the injury to the environment occurs? Finally, should the case be transferred from Lansing to Charlevoix on forum non conveniens grounds?

As to the first question, the Act rather inartfully refers in section $3(1)$ to "conduct of the defendant" that "is likely to pollute."282 While the granting of a permit does not comfortably fit within this language as conduct that itself is likely to pollute, it is clear that the legislature intended that plaintiffs be able to enjoin the granting of permits by government agencies when the use of those permits will create pollution. ${ }^{283}$ Moreover, section $5(2)$ of the Act imposes substantive duties on regulatory agencies that confirm this point. This section of the Act states that in any "administrative, licensing or other proceedings .... no conduct shall be authorized or approved which does, or is likely to ..." pollute. ${ }^{284}$

282. Mich. CoMr. LAwS ANN. § 691.1203 (Supp. 1972).

283. This issue has been raised in only one case, Beaman v. Township of Summit. The plaintiff, a township resident, claimed that failure of the township to prosecute individual polluters itself constituted "conduct ... polluting . . . the water" within the meaning of $\S 3(1)$ of the EPA. The case was unusual since the relief sought was an injunction against the township prohibiting it from building sewers for pollution treatment (as required by the Water Resources Commission). Apparently plaintiff's theory was that as a township taxpayer, he should not have to pay for the consequences of the township's failure to deal with individual polluters. The court granted summary judgment for the defendant, holding that no cause of action upon which relief could be granted had been stated. The court stated at 2 of its Opinion on Defendant's Motion for Summary Judgment that

[i]n interpreting a statute, it must be strictly construed, especially when it has not been construed by higher courts .... I agree with the defendant that interpreting the statute strictly, that the defendant would have to be alleged to be

guilty of polluting. In reading ... [the EPA] it refers to the plaintiff showing that the defendant "has polluted or is likely to pollute." ... The complaint does not claim the defendant is guilty of polluting or is doing anything that is apt to result in pollution. The plaintiff's action under the "Environmental Act" should

be brought against the individuals who are polluting and not against the defendant township.

The legislative history of the EPA is clear that the Act was explicitly intended to allow suits by private citizens against regulatory agencies to require them to fulfill their legal obligations to prosecute polluters, and to treat their failure to do so as a violation of section 3 of the Act. See note 234 supra and accompanying text. The plaintiff's problem in Beaman was that he sought the wrong relief, not that he failed to state a cause of action under the EPA.

Thus, Betz Foundry (see text accompanying notes 182-85 supra) was precisely the type of suit the legislature contemplated. This is not to say that the EPA compels mandatory enforcement of every violation, but at the least it requires a challenged nonenforcing agency to persuade the court that its restraint is consistent with the policy of the Act and art. IV, $\S 52$, of the Michigan Constitution. It might meet this burden by showing that the problem is trivial or that conciliatory tactics are more likely to be effective than rigorous enforcement.

284. Mich. CoMr. LAws ANN. \$ 691.1205 (Supp. 1972). 
As to the question where did the legislature intend venue to lie, the statute does not explicitly refer either to the place where a violation of the Act occurs or to the place where damage to the environment occurs. But it would seem natural to read the EPA as referring to a violation of the law rather than to the more poetic "violation of the environment." There is no documentary evidence on this last point, but those involved in drafting the statute did have a specific restriction in mind. They feared that some environmental problems were so pervasive that a plaintiff in the Upper Peninsula might sue there for air pollution that occurred in Detroit. ${ }^{285}$ Thus, to protect defendants, rather than speaking of the place where the injury occurred, the Act limits suit to the place or places where the defendant has acted; that is, to a place where the conduct that allegedly violated the law has occurred.

It was understood that-in cases like Tanton-this would permit suits either in Lansing or at the site of the alleged physical conduct, and thus would be consistent with the general venue provision that states: "if the cause of action arose in the county of the principal office of [a] governmental unit [that] county is the proper county in which to commence and try actions against such governmental units."288

Finally, in resolving the most-convenient-forum issue, the Tanton court, accepting the fact that venue was properly laid in Ingham County, ${ }^{287}$ nevertheless granted a permissive change of venue "for

285. Debate in the Michigan Senate, June 26, 1970 (colloquy between Senator Joseph Mack and Senator Basil Brown) (transcript on file with author).

286. Revised Juđicature Act § 1651, Mich. CoMP. LAws ANN. § 600.1615 (Supp. 1972). The venue issue arose from a suggestion of the Michigan chamber of commerce. In a memo to the legislature dated March 4,1970, the chamber's Special Legal Subcommittee suggested an amendment providing that

All actions ... shall be commenced in the circuit court for the county in which the defendant resides or has its principal place of business, or in the circuit court for the county in which the conduct... occurs, and if such occurs in more than one county, an action may be commenced in any of said counties and the circuit court for the county in which the action is first initiated shall have exclusive jurisdiction. Actions against the State of Michigan or any agency thereof shall be commenced only in Ingham County.

The provision ultimately adopted, proposed by Senator Mack, was applauded by the chamber of commerce. See Michigan State Chamber of Commerce State Legislation Report, July 29, 1970, at 4; 95 Mich. S. J. 1628.

In Lakeland the defendant township was a municipal corporation in Washtenaw County, but the sewage treatment facility at issue in the case was located in Livingston County. Thus, the defendant argued, since the general venue provision provides that proper venue in a suit against a government unit is the county in which it exercises governmental authority, venue must be laid in Washtenaw County. Motion of Defendant for a Change of Venue, Sept. 15, 1970. The court denied the motion. Lakeland Property Owners Assn. v. Township of Northfield, Order of Judge Mahinske (Oct. 7, 1970).

287. Tanton v. DNR, Order of Judge Reisig (Jan. 21, 1972). 
the convenience of parties and witnesses,"288 noting that many issues in the case involved the Charlevoix area and that the Ingham County courts were very busy. ${ }^{289}$

A somewhat more complicated problem was presented by Michigan United Conservation Club v. Anthony, a case brought against a defendant-class that included "all other persons who claim by virtue of Indian treaty rights with the United States . . . the right to fish in the waters of the State of Michigan without compliance with the provisions of the fish and game laws ... of the State of Michigan." 290 The first problem here was that Indians were fishing in Great Lakes waters that were offshore of many different counties. The question, therefore, was whether a suit filed in one circuit court would be sufficient. ${ }^{291}$ More specifically, was section 2(1) of the EPA jurisdictional, ${ }^{292}$ or did it only set venue? If it was jurisdictional, the court would have no authority over Indians who were fishing outside of the waters off Ottawa County. Relying on the Practice Commentary's provisions that relate to circuit court jurisdictions, ${ }^{203}$ the plaintiff asserted, and the court agreed, ${ }^{294}$ that section $2(1)$ of the EPA is not a jurisdictional limitation; it is simply a statement of venue.

Thus the remaining question was how to handle the specific venue provision of section $2(1)$ in a case in which the defendant class members were engaging in conduct all over the state. Since the

288. Id. See Mrch. CT. (GEN.) R. 403 (1969).

289. Author's notes taken at hearing in circuit court, Jan. 14, 1972.

290. MUCG v. Anthony, Complaint at 1. The essence of the claim was that the Indians were subject to Michigan conservation laws and that the violation thereof constituted a violation of the EPA. See text accompanying notes 49-56, 175-77 supra.

291. The defendant conceded that suit was properly brought in Ottawa County to challenge fishing off the shores of that county in Lake Michigan. MUCC v. Anthony, Transcript at 27 (Aug. 18, 1971).

292. EPA \& 2(1), Mich. CoMp. LAwS ANN. § 691.1202(1) (Supp. 1972), provides that the plaintiff "may maintain an action in the circuit court having juxisdiction where the alleged violation occurred." In Payant, the defendant argued that the preliminary injunction sought was in essence a petition for a writ of mandamus against a state officer, as to which the courts of appeals and the supreme court have exclusive jurisdiction. Revised Judicature Act \$ 4401, Micr. Comp. LAws ANN. § 600.4401; Mich. CT. (GEN.) R. \& 714.1(1) (1969), Brief of Defendants Supporting a Motion To Dismiss at 1, Payant v. DNR. See Minarik v. Ziegler, 336 Mich. 209, 57 N.W.2d 501 (1953). The court implicitly rejected this claim. Payant v. DNR, Per Curiam Opinion (Sept. 4, 1971).

293. The commentary to the Revised Judicature Act $\S 601$, Mick. Comp. Laws ANN. \$ 600.601 (1968), provides that

.. the organic law of Michigan confers jurisdiction upon the circuit courts in broad affirmative terms. ... Therefore, the basic approach to jurisdictional problems in Michigan is not a search for specific jurisdictional grants, but rather an assumption that the circuit courts have jurisdiction unless the matter in question is specifically excluded by law.

294. MUCC v. Anthony, Opinion of Judge Smith at 1 (Sept. 15, 1971). 
EPA does not speak to this precise question, the general court rules governing venue are controlling. ${ }^{205}$ On this point, the Practice Commentary states that "if the action joins defendants who are established in different counties, venue is proper in the county in which any defendant is established." ${ }^{298}$ Applying this principle to the EPA, it would seem appropriate, if the "violation occurred" in different counties, to lay venue in any county in which any violation occurred. This is the result the court ordered. ${ }^{297}$

\section{E. Security Bonds}

Section 2(a) of the EPA ${ }^{208}$ reflects the legislature's effort to accommodate preliminary injunction practices with the Act's innovative grant of standing-to-sue to private citizens and organizations that initiate litigation in the public interest. The problem here is that the general court rules governing preliminary injunctions anticipate that the plaintiff will be required to post security sufficient to cover the damages incurred by a defendant during the pendency of any injunction wrongfully granted. ${ }^{299}$

This rule usually presents no great problem since the magnitude of litigation in which private plaintiffs ordinarily become involved is closely related to their own economic standing. ${ }^{300}$ This ordinary equality of economic standing among the parties to a controversy, however, does not apply to the kind of cases contemplated by the EPA, for an EPA plaintiff is not, in most circumstances, suing to 1972).

295. Revised Judicature Act \& 1621, Mrch. Conrp. LAws ANN. $\$ 600.1621$ (Supp.

296. Commentary to Revised Judicature Act § 1621, Mick. Comp. Laws ANN. $\S 600.1621$ (Supp. 1972).

297. Anthony Opinion, supra note 294, at 1: "The nature of the subject matter of these actions indicates that Ottawa County as well as many other counties may be affected by the alleged activities of the defendants. Accordingly, it is the opinion of this court that jurisdiction lies in the Ottawa Circuit Court."

298. Mich. Comp. Laws ANN. $\$ 691.1202 a$ (Supp. 1972).

299. MrCH. CT. (GEN.) R. 718.3 (1969) provides:

The court may require the giving of security by the applicant in the sum the court deems proper, for the payment of costs and damages that may be incurred or suffered by any party who is found to have been wrongfully enjoined or restrained, before granting a preliminary injunction or restraining order. If security is not required, the order shall specifically state why security is unnecessary.

Mraf. CT. (GEN.) R. 718.11 (1969) provides: "This rule shall not apply to special statutory actions to obtain an injunction, if the statute prescribes special procedures to be followed. ..."

300. This is not always the case, and courts exercise discretion to protect the right of plaintiffs to sue effectively by waiving security or setting it very low. E.g., Powelton Civic Home Owner's Assn. v. Department of HUD, 284 F. Supp. 809, 840 (E.D. Pa. 1968); Natural Resources Defense Council v. Morton, 337 F. Supp. 167 (D.D.C. 1971); Denny v. Health \& Social Services Bd., 285 F. Supp. 526, 527 (1968). 
protect his private interests, except to a very minor degree; he sues as a "private attorney general," 301 to protect public resources. Even a brief recollection of the cases discussed above makes this clear.

Having included a broad standing-to-sue provision in the EPA, the legislature recognized that to apply the usual bond requirements governing preliminary injunction practice to such cases would undo with one hand what the legislature had just done with the other. Obviously, to expect individuals to sue to protect large tracts of public lands, or to see that fishery conservation regulations are enforced state-wide, means that they cannot be expected to bear the losses wrongfully sustained by defendants during the pendency of litigation. At the same time, to deny such plaintifts the opportunity to obtain preliminary injunctive relief is frequently to deny them any meaningful right to sue at all, for environmental cases are typically those in which failure to "stop the bulldozer" is to permit the irreversible activity that is ultimately in controversy.

The equities are not all on the side of the plaintiffs, however, for the damage incurred by a defendant under a preliminary injunction ought also to be a serious concern. A law that discourages plaintiffs from casually seeking such relief is highly desirable, too. ${ }^{302}$ Since there is no perfect accommodation of these competing interests, the EPA has tried to resolve the problem through compromise. Some protection is given to defendants, but that is accomplished without significantly restricting the plaintiff's right to sue.

Section 2(a) thus provides:

If the court has reasonable ground to doubt the solvency of the plaintiff or the plaintiff's ability to pay any cost or judgment which might be rendered against him in an action brought under this act

301. See Newman v. Piggie Park Enterprises, Inc., 390 U.S. 400, 402 (1968); Associated Indus., Inc. v. Ickes, 134 F.2d 694, 704 (2d Cir. 1943), vacated as moot, 320 U.S. 707 (1943).

302. For reasons that are not entirely clear, the good sense and restraint of judges has not been generally accepted as sufficient protection for the defendants. Notably, the Michigan law follows the general pattern in stating specifically that no security may be required of the state, a county, municipal corporation, or any officer or agency thereof, in granting preliminary relief to such a public plaintiff. MicH. CT. (GEN.) R. 718.3(2) (1969). It is not clear whether this provision merely exempts them from having to post security, or whether it also exempts them from potential damage claims arising out of a preliminary injunction found to have been wrongfully granted. We have found no case in which a governmental plaintiff has had to pay such damages. If immunity from payment of damages is the law, it reflects interestingly on the limited responsibility put on private attorney general plaintiffs under the EPA. See note 301 supra. But see Attorney General ex rel. State Banking Commr. v. Hyde, 265 Mich. 363, 368, 251 N.W. 570, 571 (1933). 
the court may order the plaintiff to post a surety bond or cash not to exceed $\$ 500.00 .808$

The provision is not felicitously drafted. It was inserted at a late stage when a number of provisions were simultaneously being revised under considerable time pressure. Nonetheless, the provision's intent was never in doubt, as the background to its enactment indicates.

The first decision made by the legislature was to limit the amount of security that could be required when a preliminary injunction is issued. ${ }^{304}$ This amount was originally set at $\$ 300$, but raised to $\$ 500$ in response to requests that it be made as high as $\$ 3,000 . .^{305}$ There was some concern that even a modest security that had to be supplied during litigation would be undesirable for a publicly concerned plaintiff who might have very limited resources at hand. However, the legislature was persuaded that some disincentive should be imposed on a plaintiff with no resources who might be called upon to pay for damages resulting from an injunction wrongfully issued.

As a result of the discussions, a distinction between insolvent plaintiffs and those who were not judgment-proof was drawn. It was thought that subjecting a solvent plaintiff's assets to risk would be in itself a sufficient deterrent so that these plaintiffs should not be placed under the additional burden of putting up even 500 extra dollars to support their litigation. As to plaintiffs who might have no such self-restraint because they were essentially without assets, it was decided to protect defendants by requiring these plaintiffs to post security, if the judge thought it desirable. The purpose, then, of section 2(a) is to provide that (1) Solvent plaintiffs need not post any security to obtain a preliminary injunction; (2) Plaintiffs whose solvency the court has reasons to doubt may be required to post security to obtain a preliminary injunction, but not more than $\$ 500$; (3) The liability of all plaintiffs, solvent and insolvent alike, is limited to a maximum of $\$ 500$ for losses incurred if the preliminary injunction is determined to have been wrongfully granted. ${ }^{300}$

303. MrCh. CoMr. LAwS ANN. \& 691.1202a (Supp. 1972).

304. The provisions of section 2(a) of the EPA are intended to apply only to preliminary injunctions, the problem dealt with in Mrcr. Cr. (GEN.) R. 718.3 (1969).

305. Michigan Manufacturers Association Newsletter, May 13, 1970, at 3 (statement on H.B. 3055).

306. There was no bond provision in the original bill. This issue was first raised by the state chamber of commerce in its State Legislation Report, Feb. 27, 1970, at 3. On March 4, 1970, the chamber's Special Legal Subcommittee, in a memo prepared for the legislature, suggested the following amendment, at 2:

The court may require the giving of security in the sum the court deems proper for the payment of costs and damages that may be incurred or suffered by any 
Thus far the bond issue has arisen in controversial fashion in only one case, Blunt $v$. Apfel. ${ }^{307}$ The suit involved an attempt to enjoin a proposed condominium development. According to the plaintiff, the arrangements for disposing of the development's sewage would pollute the lake on which the development was to be located. The judge found no present danger in the project and refused to grant a preliminary injunction, but he retained jurisdiction in the event that damage could be shown after the project commenced. The court's comments on the bond issue are all by way of dictum, but they are nonetheless significant for their rather exotic interpretation of section 2(a):

Such a provision could well allow any person on the welfare rolls to start an action to delay an honest building project of millions of dollars and is therefore, in the opinion of this Court, an invasion by the legislative branch of the Government of the right of the judicial branch of the Government to exercise judicial discretion as to the amount of indemnity to be required of a party starting suit before restraining work on such project.

...

This Court does hereby specifically find that defendants [sic] are not insolvent and in the event any further proceedings to restrain this condominium project of over Two Million Dollars are sought,

party who is found to have been wrongfully enjoined or restrained. If security is not required, the order shall specifically state why security is unnecessary.

On April 20, 1970, Rep. Rohlfs proposed an amendment to the bill allowing bond to be required without any limit. This proposal was rejected. 56 Mich. H.J. at 1273 (1970). The next day he amended his proposal to provide that "the court may order the plaintiff to post a bond or cash not to exceed $\$ 300.00 . "$ This was accepted. 57 Mich. H.J. at 1296 (1970). The amount was ultimately raised to $\$ 500.00$ by the Senate. 95 Mich. S.J. 1267 (1970).

Each of the proposals above contained the "solvency" language that now appears in the bill. We have not been able to find any formal record of discussion on this matter. Following the adoption of the Senate provision, the UPI story on the bill reported:

One of the amendments adopted raises from $\$ 300$ to $\$ 500$ the amount of bond a complainant would have to post if the court had "reasonable ground" to suspect he did not have the money to pay any costs that might be rendered against him. Sponsors of the change said the money increase would prevent frivolous lawsuits.

Ann Arbor News, June 27, 1970, at 9, col. 1.

307. Blunt Decision, supra note 180. See also Blunt v. Apfel, Transcript at 29 (Dec. 10, 1970), where the judge noted: "Well, I will say this: I am not in agreement with only a $\$ 500$ bond, as required. I don't think that is anywhere near adequate." In Tanton, Judge Reisig's Order of Dec. 16, 1971, granting a temporary restraining order, declared that "Since the Court has no reasonable ground to doubt the solvency of the Plaintiff . . . no bond is required." In both Gang of Lakes and Wilcox, the ex parte restraining order carried the notation: "No bond is required because a public question is involved and no economic interest of the Defendant is attacked or threatened." In Leelanau, the order stated: "It is further ordered that no security be required of the Plaintiffs." The order in Ray simply said "No bond shall be required." Bond was waived by the County in Muskegon County (cross complaint). 
will require plaintiff to furnish an Indemnity Bond of between Fifty and One Hundred Thousand Dollars. ${ }^{308}$

\section{Conclusion}

In the first sixteen months following enactment of the EPA, several dozen cases moved steadily through Michigan's courtrooms demonstrating that citizen participation is not an empty slogan. The Act, though still very young, has strikingly emphasized several important points.

(1) Government and industry are highly inertial, but when prodded from without, they are quite capable of responding to pressures for reform.

(2) Regulatory agencies are more often victims than villains, and well-placed lawsuits naming them as defendants can liberate them from unwarranted political pressures.

(3) Experts, however well intentioned, do not have all the answers. Far more than is generally believed, the application of well-informed common sense is the vital ingredient in resolving environmental controversies.

It is not necessary here to reiterate the specific findings detailed in this Article. Suffice it to say that enough cases have been resolved speedily and intelligently to mark the Act as a success. This is not to suggest that every case has come to a commendable conclusion. We have seen ill-considered and ill-prepared suits that fell of their own weight. We have judges who failed to face the responsibilities that the Act imposed upon them; and we have seen attorneys who interposed unnecessary and undesirable technical objections. We have seen, too, that money is an issue. The inability of plaintiffs to recruit expert witnesses or to launch expensive, full-scale litigation has certainly undermined the potential usefulness of some cases, and has prevented others even from being filed. ${ }^{309}$

The true success of the EPA, however, cannot be measured either in the cold statistics of cases or in a closely reasoned analysis of the statute's provisions. More than anything else, the Act has instilled in ordinary citizens a confidence that it is possible for them to have their day in court-in the fullest meaning of that phrase. Too often stu-

308. Blunt Order, supra note 180, at 3-5.

309. For example, plans to file an EPA suit in Ann Arbor to challenge a proposed condominium development adjacent to Bird Hills Park was abandoned because:

We were told that to start a suit would cost $\$ 4,000$ to $\$ 6,000$, and it was open ended from there. Depending on the need for experts and how far it was neces. sary to carry the case, it could cost as much as $\$ 30,000$ to $\$ 60,000$. People were willing to commit themselves to some extent, but not to that level. . . They were willing to put up hundreds, but not thousands.

Author's interview with Mrs. M. Sahlins, March 15, 1972. 
dents of the administrative process forget that behind the formal cases are always human problems. To some official, a new highway may be another link in a grandiose transportation network; to the individual in its path, it is a swath dividing the neighborhood in which he has chosen to live and to raise his children. A small trout stream or scenic woodland that is only an impediment to large-scale planners is often a special source of joy and refreshment to those who come back to it season after season seeking repose.

These values, unpretentious as they are, lie deep in the hearts of many of our citizens, people who are unable to support representatives in the capital or to buy slick advertising in the mass media. These are the people to whom the EPA speaks. And, as we have seen, it is they who have most often used the Act. They have not always prevailed, but they have had ample opportunity to be heard; and in almost every instance, they have received fair and intelligent treatment by the courts.

As noted earlier, the Act has been used affirmatively by public officials more often than we expected. To us, this development has been a happy bonus of the EPA for it indicates an unexpected public willingness to remedy environmental problems that only needed the encouragement of a strongly worded legislative mandate. However, court cases alone cannot significantly ameliorate environmental problems. In this regard, the evidence cited above of modified procedures by the Air Pollution Control Commission, of enlarged perspectives by the Public Service Commission, and of the whole panoply of new initiatives in land use control by the Natural Resources Commission, is hopeful.

Whether the Act will fulfill its larger promise remains to be seen. The ultimate issue is whether a fast-moving and complex society can still afford to pause and permit an ordinary citizen to play a role in the formulation of public policy. The EPA is a small but significant affirmation of confidence in the citizen. Thus far the evidence is encouraging that the legislature's trust has not been misplaced. 
APPENDIX A

Trtue, Date, and Place of Cases filed *

\begin{tabular}{|c|c|c|c|c|}
\hline & Title of Case & File No. & Date Filed & County \\
\hline 1. & $\begin{array}{l}\text { Alvin E. Bertrand, Inc. } \\
\text { v. City of Detroit }\end{array}$ & $191-622$ & $10 / 12 / 71$ & Wayne \\
\hline 2. & Beach v. Detroit Edison Co.1 & 5993 & $9 / 9 / 71$ & Washtenaw \\
\hline 3. & $\begin{array}{l}\text { Beaman v. Township of } \\
\text { Summit }\end{array}$ & C11-212 & $9 / 10 / 71$ & Jackson \\
\hline 4. & Bise v. Detroit Edison Co. & 181665-S & $5 / 24 / 71$ & Wayne \\
\hline $\mathbf{5 .}$ & Blunt v. Apfel2 & 849 & $\begin{array}{l}11 / 4 / 70 \\
\text { (amended } \\
\text { complaint) }\end{array}$ & Antrim \\
\hline 6. & $\begin{array}{l}\text { Brown v. Lever } \\
\text { Bros. Co. }\end{array}$ & 161228 & $\begin{array}{l}2 / 15 / 71 \\
(3 \mathrm{~d} \\
\text { amended } \\
\text { complaint) }\end{array}$ & Wayne \\
\hline 7. & $\begin{array}{l}\text { Busard v. Muskegon } \\
\text { Heights }\end{array}$ & 5291 & $10 / 27 / 70$ & Muskegon \\
\hline 8. & Crandall v. Biergans & 844 & $\begin{array}{l}6 / 11 / 69 \\
\text { (amended } \\
\text { complaint) } \\
9 / 3 / 71\end{array}$ & Clinton \\
\hline 9. & $\begin{array}{l}\text { Davis v. Dept. of } \\
\text { Natural Resources (DNR) }\end{array}$ & 482 & $10 / 1 / 70$ & Otsego \\
\hline 10. & $\begin{array}{l}\text { Gang of Lakes Env. Org. } \\
\text { v. Gee }\end{array}$ & 7 & $1 / 19 / 72$ & Calhoun \\
\hline 11. & $\begin{array}{l}\text { Hadley Township v. } \\
\text { Dept. of Natural } \\
\text { Resources (DNR) }\end{array}$ & $3454-B$ & $10 / 14 / 71$ & Lapeer \\
\hline 12. & $\begin{array}{l}\text { Kelley v. Tannehill } \\
\text { \& DeYoung, Inc. }\end{array}$ & 2626 & $11 / 4 / 71$ & $\begin{array}{l}\text { Grand } \\
\text { Traverse }\end{array}$ \\
\hline 13. & $\begin{array}{l}\text { Lakeland Property Owners } \\
\text { Assn. v. Township of } \\
\text { Northfield }\end{array}$ & 1453 & $8 / 27 / 70$ & Livingston \\
\hline 14. & $\begin{array}{l}\text { Leelanau County Bd. of } \\
\text { Commrs. v. Dept. of Natural } \\
\text { Resources (DNR) }\end{array}$ & 510 & $3 / 1 / 71$ & Leelanau \\
\hline 15. & $\begin{array}{l}\text { Marble Chain of Lakes } \\
\text { v. Water Resources Commn. } \\
\text { (WRC) }\end{array}$ & $235-70$ & $12 / 14 / 70$ & Branch \\
\hline 16. & $\begin{array}{l}\text { McCloud v. City of } \\
\text { Lansing }\end{array}$ & 13057-C & $4 / 23 / 71$ & Ingham \\
\hline 17. & $\begin{array}{l}\text { Michigan Consolidated } \\
\text { Gas Co. }\end{array}$ & U-3802 & $1 / 11 / 71$ & $\begin{array}{l}\text { Public } \\
\text { Serv. } \\
\text { Commn. }\end{array}$ \\
\hline 18. & $\begin{array}{l}\text { Michigan Consolidated Gas } \\
\text { Co. \& Consumers Power Co. }\end{array}$ & $\begin{array}{l}\text { U-3933 } \\
\text { U-3935 }\end{array}$ & $\begin{array}{l}7 / 15 / 71 \\
\text { (notice of } \\
\text { interven- } \\
\text { tion) }\end{array}$ & $\begin{array}{l}\text { Public } \\
\text { Serv. } \\
\text { Commn. }\end{array}$ \\
\hline 19. & $\begin{array}{l}\text { Michigan United } \\
\text { Conservation Clubs } \\
\text { (MUCC) v. Anthony }\end{array}$ & 2331 & $8 / 2 / 71$ & Ottawa \\
\hline 20. & $\begin{array}{l}\text { Muskegon County v. En- } \\
\text { vironmental Protection Org. }\end{array}$ & C-5585 & $3 / 15 / 71$ & Muskegon \\
\hline
\end{tabular}


APPENDIX A (Continued)

\begin{tabular}{|c|c|c|c|c|}
\hline & Title of Case & File No. & Date Filed & County \\
\hline 21. & $\begin{array}{l}\text { Owens v. Water Resources } \\
\text { Commn. (WRC) }\end{array}$ & 5708 & $5 / 14 / 71$ & Washtenaw \\
\hline 22. & $\begin{array}{l}\text { Payant v. Dept. of } \\
\text { Natural Resources (DNR) }\end{array}$ & 1100 & $7 / 13 / 71$ & Dickinson \\
\hline 23. & Ray v. Raynowsky & $2-760$ & $11 / 17 / 71$ & Mason \\
\hline 24. & Reume v. Herrick & 180998R & $5 / 21 / 71$ & Wayne \\
\hline 25. & Roberts v. Michigan & $12428-\mathrm{C}$ & $10 / 23 / 70$ & Ingham \\
\hline 26. & $\begin{array}{l}\text { Surowitz v. City of } \\
\text { Detroit }\end{array}$ & 178,640 & $4 / 12 / 71$ & Wayne \\
\hline 27. & $\begin{array}{l}\text { Tanton v. Dept. of } \\
\text { Natural Resources (DNR) } 4\end{array}$ & $13859-\mathrm{C}$ & $12 / 8 / 71$ & Ingham \\
\hline 28. & $\begin{array}{l}\text { Trout Unlimited } \mathbf{v} \text {. } \\
\text { Milliken }\end{array}$ & $13243-\mathrm{G}$ & $6 / 18 / 71$ & Ingham \\
\hline 29. & $\begin{array}{l}\text { Water Resources Commn. } \\
\text { (WRC) v. Chippewa County }\end{array}$ & 1255 & $2 / 10 / 71$ & Chippewa \\
\hline 30. & $\begin{array}{l}\text { Wayne County Health Dept. } \\
\text { (WCHD) v. American } \\
\text { Cement Co. }\end{array}$ & 194927-R & $11 / 29 / 71$ & Wayne \\
\hline 31. & $\begin{array}{l}\text { Wayne County Health Dept. } \\
\text { (WCHD) v. Edw. Levy Co. }\end{array}$ & $166-224$ & $10 / 1 / 70$ & Wayne \\
\hline 32. & $\begin{array}{l}\text { Wayne County Health Dept. } \\
\text { (WCHD) v. Chrysler Corp. }\end{array}$ & $166-223$ & $10 / 1 / 70$ & Wayne \\
\hline 33. & $\begin{array}{l}\text { Wayne County Health Dept. } \\
\text { (WCHD) v. National Steel } \\
\text { Corp. } 5\end{array}$ & 187 905-R & $8 / 20 / 71$ & Wayne \\
\hline 34. & $\begin{array}{l}\text { Wayne County Health Dept. } \\
\text { (WCHD) v. McLouth Steel } \\
\text { Corp. }\end{array}$ & 166,222 & $10 / 1 / 70$ & Wayne \\
\hline 35. & $\begin{array}{l}\text { West Michigan Env. Action } \\
\text { Council (WMEAC) v. Betz } \\
\text { Foundry, Inc. }\end{array}$ & 11409 & $3 / 12 / 71$ & Kent \\
\hline 36. & Wilcox v. Board of Rd. Commrs. & $7-237$ & $6 / 16 / 71$ & Calhoun \\
\hline
\end{tabular}

1. Collateral case In re Detroit Edison Co., No. 580068 (P. Ct., Washtenaw County) (condemnation proceedings).

2. Consolidated with Ware Real Estate Corp. v. Forest Home Township, No. 880 (Cir. Ct., Antrim County). Collateral case Apfel v. Cook, No. 926 (Cir. Ct., Antrim County) (suit by developers against plaintiffs for damages).

3. Collateral case Fisher v. Morton, No. G302-71 C.A. (W.D. Mich.) (to enjoin United States Park Service from proceeding with development of park).

4. Change of Venue to Charlevoix County granted.

5. Collateral case WCHD v. National Steel Corp., C.A. No. 37111 (E.D. Mich. filed Sept. 16, 1971) (removed) (order of remand Nov. 11, 1971). study.

- See note 13 supra for a list of cases filed subsequent to the closing date of this 


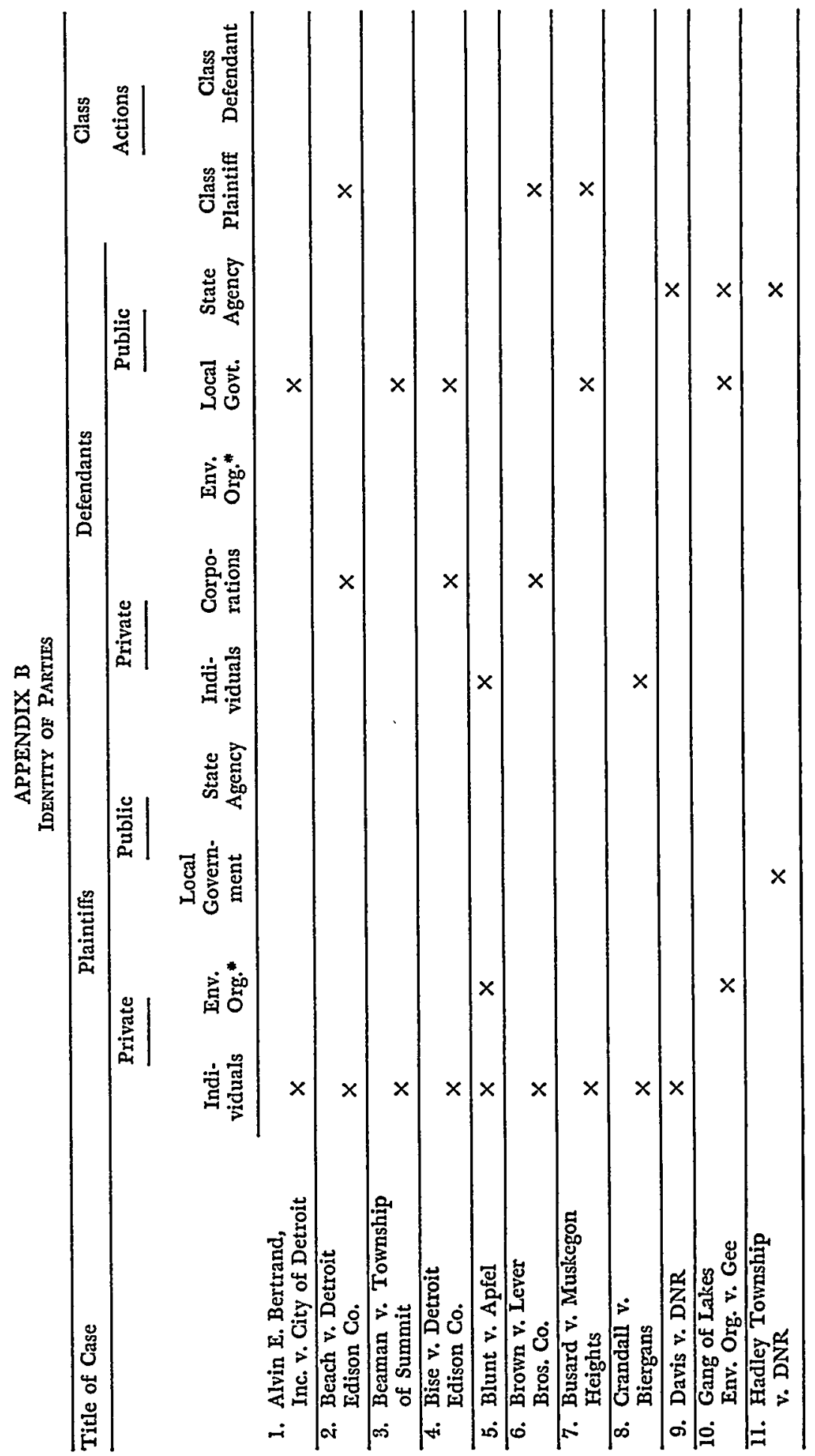


May 1972] Michigan's Environmental Protection Act

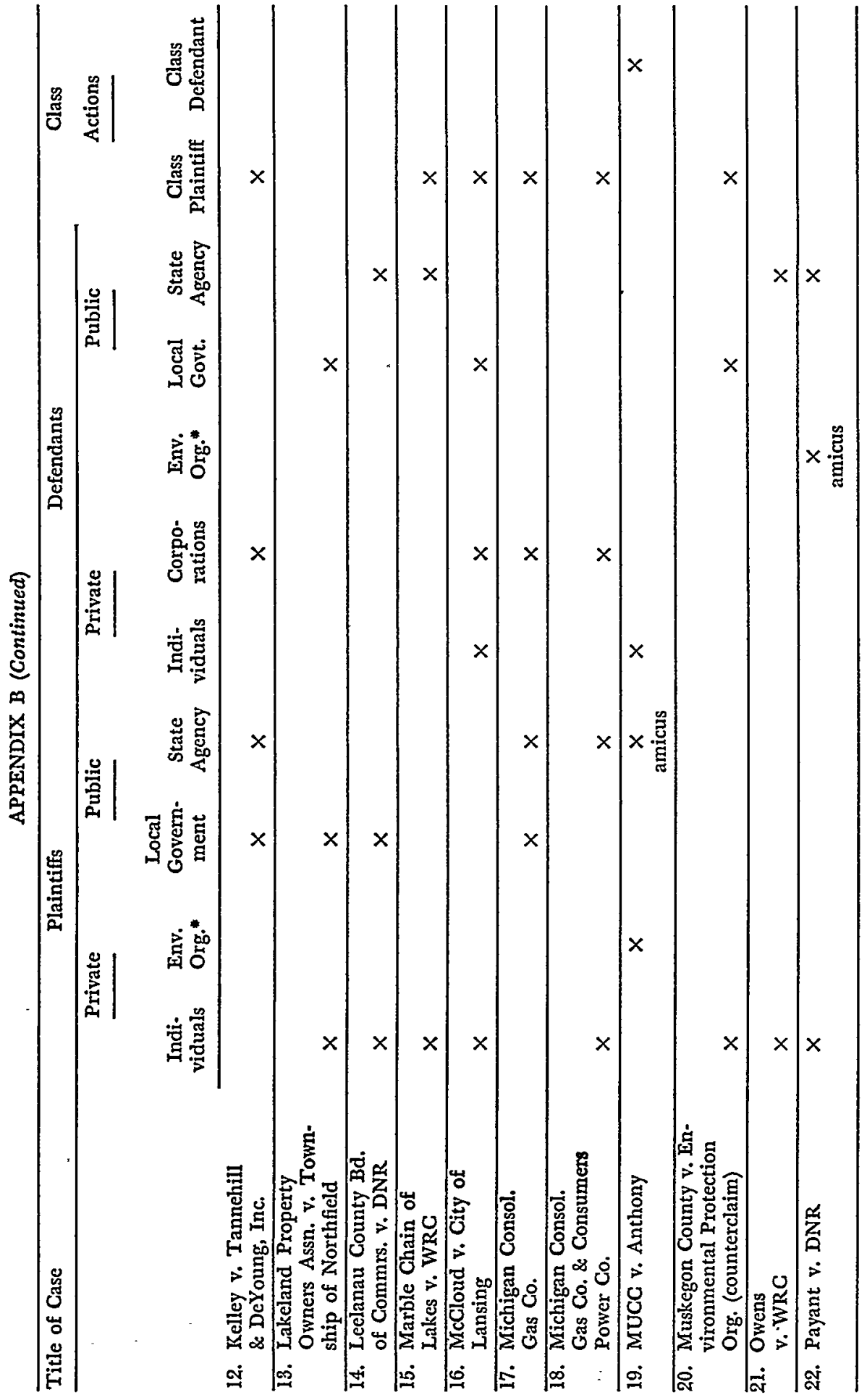




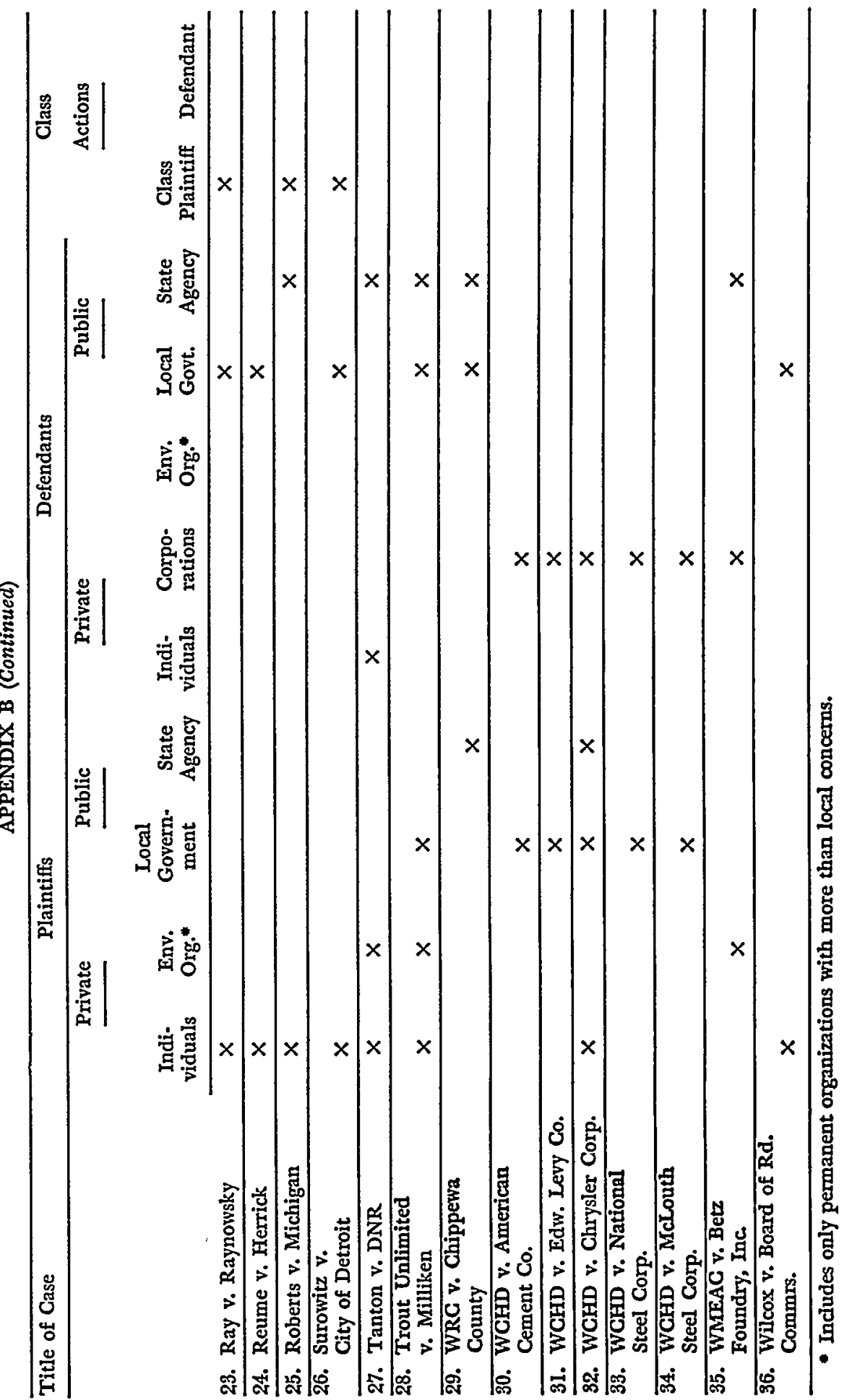


APPENDIX C

Public Agencies and Environmental Organizations InVolved in CASES FILED UNDER THE EPA

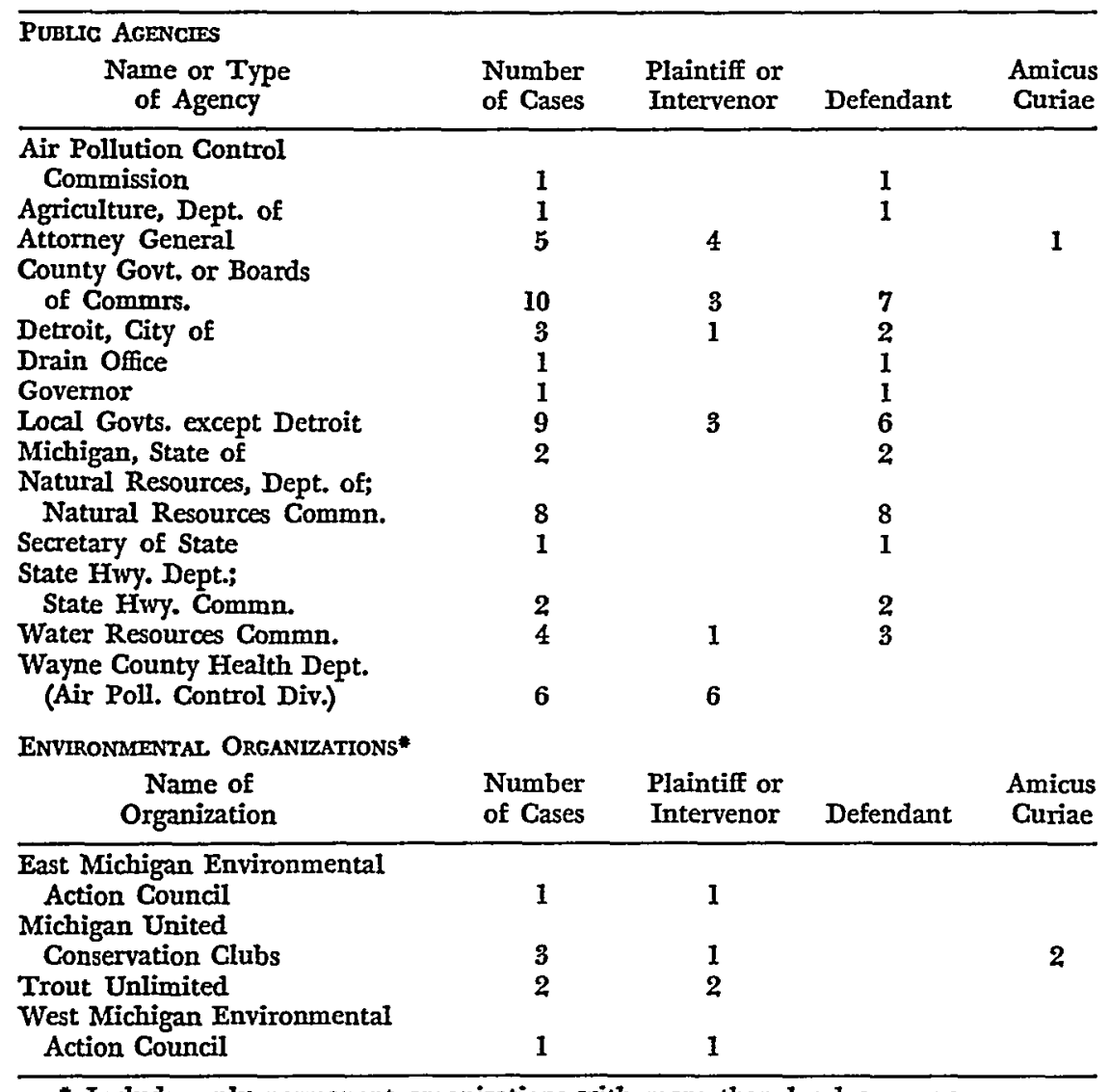

* Includes only permanent organizations with more than local concerns. 


\section{APPENDIX D}

Titles of Gases in Which Public Agencies and Environmental OrGaNIZATIONS WERE INVOLVED

\begin{tabular}{|c|c|}
\hline Public Agenctes & $\begin{array}{c}\text { TrTLES of CASES } \\
(\mathrm{P}=\text { Plaintiff; } \mathrm{D}=\mathrm{Defendant;} \\
\mathrm{A}=\text { Amicus Curiae; } \mathrm{I}=\text { Intervenor })\end{array}$ \\
\hline $\begin{array}{l}\text { Air Pollution Control } \\
\text { Commission }\end{array}$ & WMEAC v. Betz Foundry, Inc. (D) \\
\hline Agriculture, Dept. of & Gang of Lakes Env. Org. v. Gee (D) \\
\hline Attorney General & $\begin{array}{l}\text { Michigan Consol. Gas Co. \& } \\
\text { Consumers Power Co. (I) } \\
\text { Michigan Consol. Gas Co. (I) } \\
\text { Kelley v. Tannehill \& DeYoung, Inc. (I) } \\
\text { MUCG v. Anthony (A) } \\
\text { WCHD v. Chrysler Corp. (P) }\end{array}$ \\
\hline $\begin{array}{l}\text { County Governments or } \\
\text { Boards of Commrs. }\end{array}$ & $\begin{array}{l}\text { Trout Unlimited v. Milliken (P \& D) } \\
\text { Kelley v. Tannehill \& DeYoung, Inc. (P) } \\
\text { Leelanau County Bd. of Commrs. v. DNR (P) } \\
\text { Ray v. Raynowsky (D) } \\
\text { Muskegon County v. Environmental } \\
\text { Protection Org. (D) } \\
\text { Reume v. Herrick (D) } \\
\text { WRC v. Chippewa County (D) } \\
\text { Wilcox v. Board of Rd. Commrs. (D) } \\
\text { Gang of Lakes Env. Org. v. Gee (D) }\end{array}$ \\
\hline Detroit, City of & $\begin{array}{l}\text { WCHD v. American Cement Co. (P) } \\
\text { Surowitz v. City of Detroit (D) } \\
\text { Alvin E. Bertrand, Inc. v. Gity of Detroit (D) }\end{array}$ \\
\hline Drain Office & Gang of Lakes Env. Org. v. Gee (D) \\
\hline Governor & Trout Unlimited v. Milliken (D) \\
\hline $\begin{array}{l}\text { Local Governments } \\
\text { except Detroit }\end{array}$ & $\begin{array}{l}\text { Leelanau County Bd. of Commrs. v. DNR (P) } \\
\text { Hadley Township v. DNR (P) } \\
\text { Lakeland Property Owners Assn. v. } \\
\text { Township of Northfield (P\&D) } \\
\text { Muskegon County v. Environmental } \\
\text { Protection Org. (D) } \\
\text { Beaman v. Township of Summit (D) } \\
\text { Bise v. Detroit Edison Co. (D) } \\
\text { Busard v. Muskegon Heights (D) } \\
\text { McCloud v. City of Lansing (D) }\end{array}$ \\
\hline Michigan, State of & $\begin{array}{l}\text { Roberts v. Michigan (D) } \\
\text { Leelanau County Bd. of Commrs. v. DNR (D) }\end{array}$ \\
\hline $\begin{array}{l}\text { Natural Resources, Dept. of; } \\
\text { Natural Resources Commn. }\end{array}$ & $\begin{array}{l}\text { Hadley Township v. DNR (D) } \\
\text { Leelanau County Bd. of Commrs. v. DNR (D) } \\
\text { Marble Chain of Lakes v. WRC (D) } \\
\text { Payant v. DNR (D) } \\
\text { Tanton v. DNR (D) } \\
\text { Trout Unlimited v. Milliken (D) } \\
\text { Davis v. DNR (D) } \\
\text { Gang of Lakes Env. Org. v. Gce (D) }\end{array}$ \\
\hline Secretary of State & Roberts v. Michigan (D) \\
\hline
\end{tabular}


APPENDIX D (Continued)

\begin{tabular}{|c|c|}
\hline $\begin{array}{l}\text { State Highway Dept.; } \\
\text { State Highway Commn. }\end{array}$ & $\begin{array}{l}\text { Roberts v. Michigan (D) } \\
\text { WRC v. Chippewa County (D) }\end{array}$ \\
\hline Water Resources Commn. & $\begin{array}{l}\text { WRC v. Chippewa County (P) } \\
\text { Marble Chain of Lakes v. WRG (D) } \\
\text { Owens v. WRC (D) } \\
\text { Gang of Lakes Env. Org. v. Gee (D) }\end{array}$ \\
\hline $\begin{array}{l}\text { Wayne County Health Dept. } \\
\text { (Air Poll. Control Div.) }\end{array}$ & $\begin{array}{l}\text { Michigan Consol. Gas Co. (I) } \\
\text { WGHD v. American Cement Co. (P) } \\
\text { WCHD v. Chrysler Corp. (P) } \\
\text { WCHD v. Edw. Levy Co. (P) } \\
\text { WCHD v. McLouth Steel Corp. (P) } \\
\text { WCHD v. National Steel Corp. (P) }\end{array}$ \\
\hline \multicolumn{2}{|l|}{ ENVIRONMENTAL ORGANIZATIONS } \\
\hline $\begin{array}{l}\text { East Michigan Environmental } \\
\text { Action Council }\end{array}$ & Tanton v. DNR (P) \\
\hline $\begin{array}{l}\text { Michigan United Conservation } \\
\text { Clubs }\end{array}$ & $\begin{array}{l}\text { MUCC v. Anthony (P) } \\
\text { Payant v. DNR (A) } \\
\text { Tanton v. DNR (A) }\end{array}$ \\
\hline Trout Unlimited & $\begin{array}{l}\text { Tanton v. DNR (P) } \\
\text { Trout Unlimited v. Milliken (P) }\end{array}$ \\
\hline $\begin{array}{l}\text { West Michigan Environmental } \\
\text { Action Council }\end{array}$ & WMEAC v. Betz Foundry, Inc. (P) \\
\hline
\end{tabular}


APPENDIX E

Types of Cases Filed Under the EPA, by Subject Matter

\begin{tabular}{|c|c|c|}
\hline Type of Case & $\begin{array}{l}\text { No. of } \\
\text { Cases }\end{array}$ & Short Title of Cases \\
\hline \multicolumn{3}{|l|}{ Pesticides } \\
\hline Municipal Spray Program & 1 & Surowitz v. City of Detroit \\
\hline \multicolumn{3}{|l|}{ Land Use } \\
\hline Land Drainage & 2 & $\begin{array}{l}\text { Gang of Lakes Env. Org. v. Gec; } \\
\text { Ray v. Raynowsky }\end{array}$ \\
\hline Pipeline Location & 1 & $\begin{array}{l}\text { Michigan Consol. Gas Co. \& Con- } \\
\text { sumers Power Co . }\end{array}$ \\
\hline Dam \& Homesite Development & 1 & Tanton v. DNR \\
\hline $\begin{array}{l}\text { Road Widening-Tree Cutting } \\
\text { Park Management }\end{array}$ & $\begin{array}{l}1 \\
2\end{array}$ & $\begin{array}{l}\text { Wilcox v. Board of Rd. Commrs. } \\
\text { Leelanau County Bd. of Commrs. } \\
\text { v. DNR } \\
\text { McCloud v. Gity of Lansing }\end{array}$ \\
\hline Oil and Gas Leasing & 1 & Davis v. DNR \\
\hline $\begin{array}{l}\text { Condemnation by Utilities } \\
\text { Solid Waste Disposal }\end{array}$ & $\begin{array}{l}1 \\
1\end{array}$ & $\begin{array}{l}\text { Beach v. Detroit Edison Co. } \\
\text { Hadley Township v. DNR }\end{array}$ \\
\hline \multicolumn{3}{|l|}{ Air Pollution } \\
\hline Industrial & 9 & $\begin{array}{l}\text { WMEAC v. Betz Foundry, Inc.; } \\
\text { WCHD v. Chrysler Corp.; } \\
\text { WCHD v. Edw. Levy Co.; WCHD } \\
\text { v. McLouth Steel Corp.; WCHD v. } \\
\text { Great Lakes Steel Corp.; WCHD } \\
\text { v. American Cement Co.; } \\
\text { Kelley v. Tannehill \& DeYoung, } \\
\text { Inc.; Crandall v. Biergans; } \\
\text { Bise v. Detroit Edison Co. }\end{array}$ \\
\hline Automobiles & 1 & Roberts v. Michigan \\
\hline $\begin{array}{l}\text { Natural Gas Allocation } \\
\text { Municipal Incineration }\end{array}$ & $\begin{array}{l}1 \\
1\end{array}$ & $\begin{array}{l}\text { Michigan Consol. Gas Co. } \\
\text { Alvin E. Bertrand, Inc. } \\
\text { v. City of Detroit }\end{array}$ \\
\hline \multicolumn{3}{|l|}{ Water Pollution } \\
\hline $\begin{array}{l}\text { Phosphate Detergents } \\
\text { Ground Water Contamination } \\
\text { Municipal and Private } \\
\text { Treatment Systems }\end{array}$ & $\begin{array}{l}1 \\
1 \\
8\end{array}$ & $\begin{array}{l}\text { Brown v. Lever Bros. Co. } \\
\text { WRC v. Chippewa County } \\
\text { Reume v. Herrick; Owens v. } \\
\text { WRC; Muskegon County v. Envi- } \\
\text { ronmental Protection Org.; Lake- } \\
\text { land Property Owners Assn. v. } \\
\text { Township of Northfield; Busard } \\
\text { v. Muskegon Heights; Blunt v. } \\
\text { Apfel; Beaman v. Township of } \\
\text { Summit; Marble Chain of Lakes } \\
\text { v. WRC }\end{array}$ \\
\hline \multicolumn{3}{|l|}{ Water Management } \\
\hline $\begin{array}{l}\text { Lake Level Maintenance } \\
\text { and Drainage }\end{array}$ & 1 & $\begin{array}{l}\text { Trout Unlimited v. } \\
\text { Crawford County }\end{array}$ \\
\hline \multicolumn{3}{|l|}{ Fish and Game Management } \\
\hline $\begin{array}{l}\text { Deer Hunting } \\
\text { Indian Fishing Rights }\end{array}$ & $\begin{array}{l}1 \\
1\end{array}$ & $\begin{array}{l}\text { Payant v. DNR } \\
\text { MUCC v. Anthony }\end{array}$ \\
\hline
\end{tabular}


WON-LOST Record of CASES FILED UNDER THE EPA

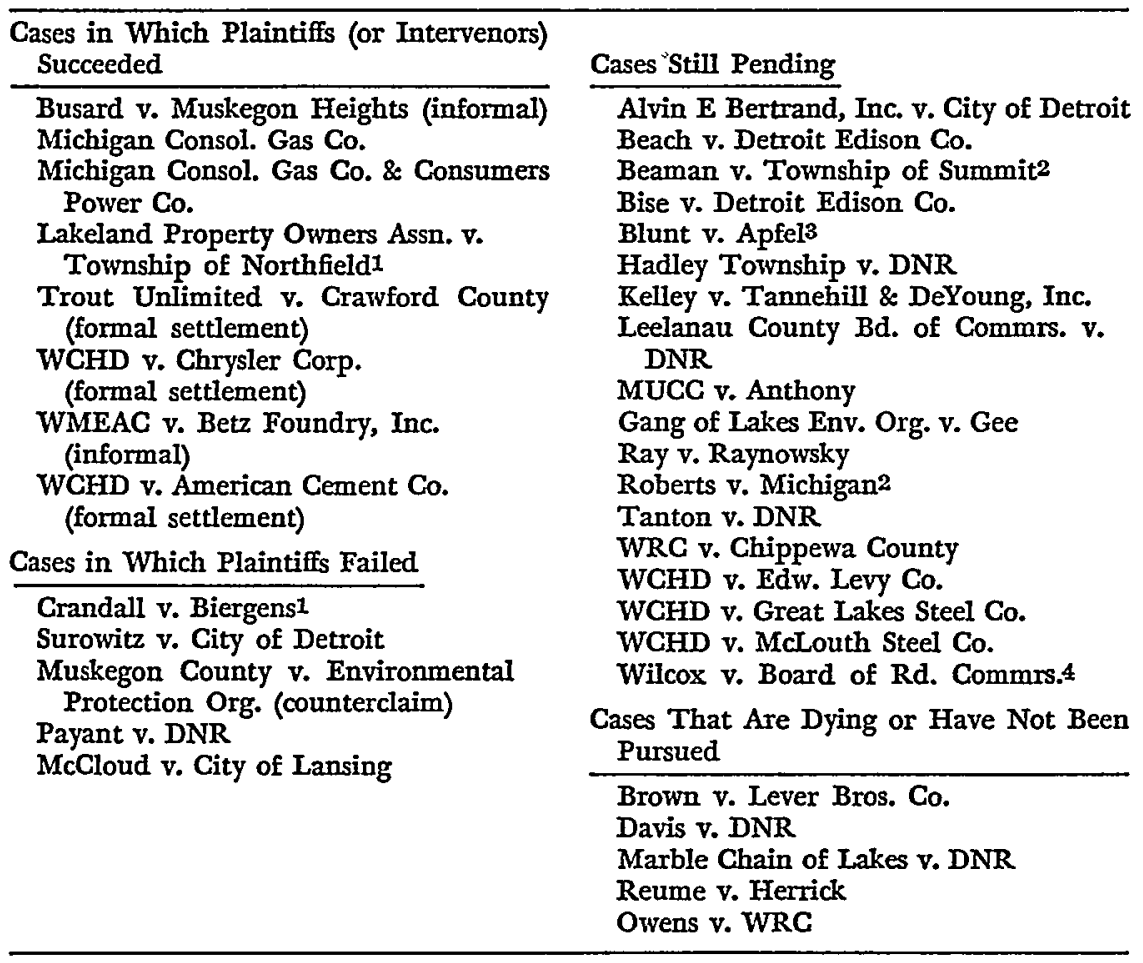

1. Case may be appealed.

2. Case on appeal, plaintiff lost in circuit court.

3. Status uncertain; Defendant won partial summary judgment. Case may go to trial.

4. The court of appeals reinstated preliminary injunction pending trial on the merits. 
APPENDIX G

Duration of Cases

Cases Completed

From Initiation to Termination

Months

Title of Cases

$\begin{array}{lllllllllllllllll}1 & 2 & 3 & 4 & 5 & 6 & 7 & 8 & 9 & 10 & 11 & 12 & 13 & 14 & 15 & 16 & 17\end{array}$

Busard v. Muskegon

Heights (voluntary

dismissal-settled)

Crandall v. Biergans

(judgment for defendant

after full trial)1

Lakeland Property Owners

Assn. v. Township of Northfield (judgment

for plaintiffs after full trial)

McCloud v. Gity of Lansing (preliminary injunction denied)

Michigan Consol. Gas Co. (order issued granting relief sought)

Michigan Consol. Gas Co. \& Consumers Power Co. (order issued granting relief sought)

Muskegon County v. Environmental Protection Org. (judgment for original plaintiff, EPA defendant, after full trial)

Payant v. DNR (judgment for defendant after full trial)

Surowitz v. City of Detroit (plaintiffs' application for T.R.O. denied)

Trout Unlimited v. Milliken (consent order issued)

WCHD v. American Cement Co. (consent judgment)

WCHD v. Chrysler Corp. (consent judgment)

WMEAC v. Betz Foundry, Inc. (informally concluded) 2

1. Case filed as nuisance action before EPA became effective.

2. Equipment purchased but not yet installed; appeal pending on collateral issue. 


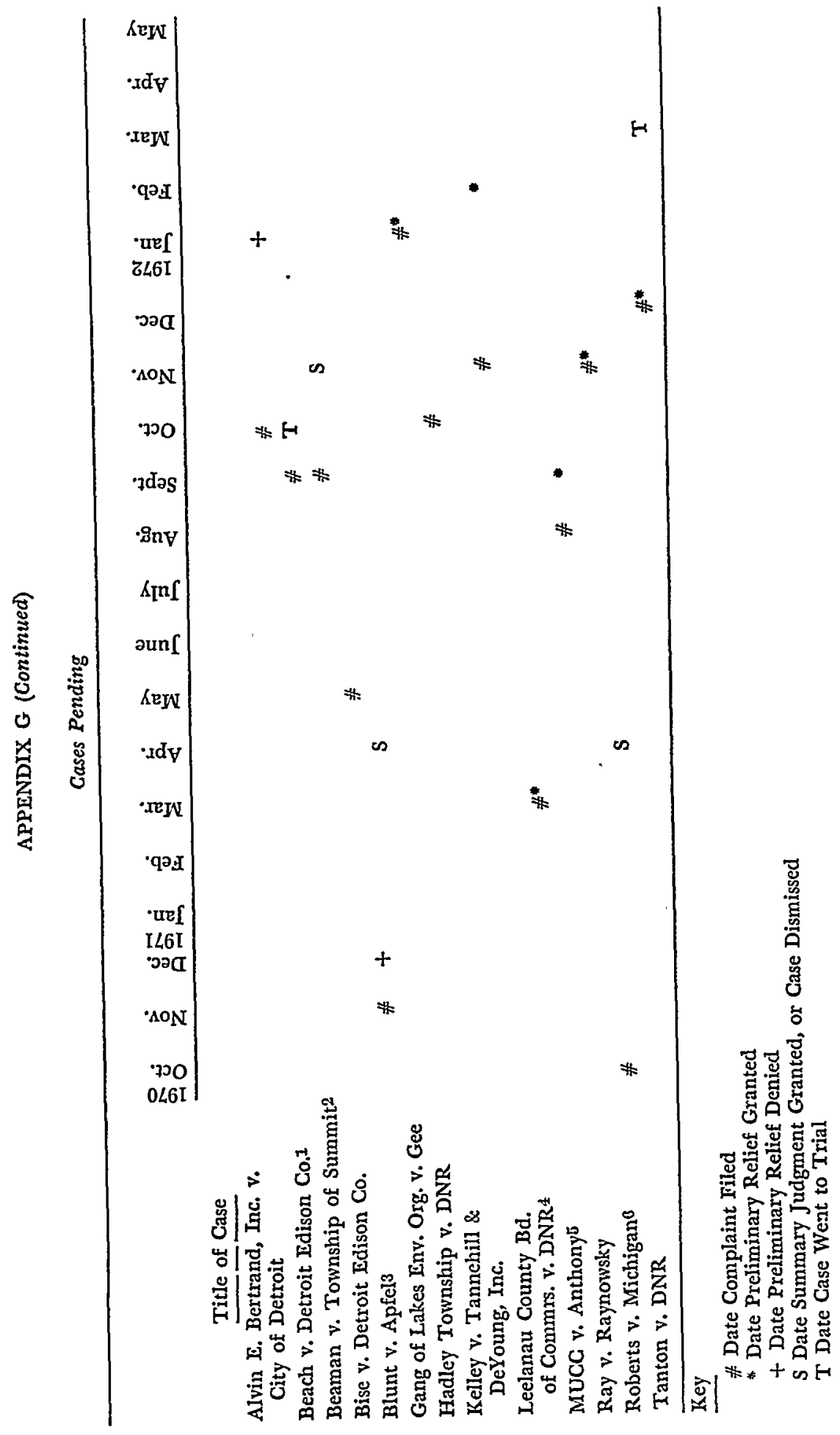




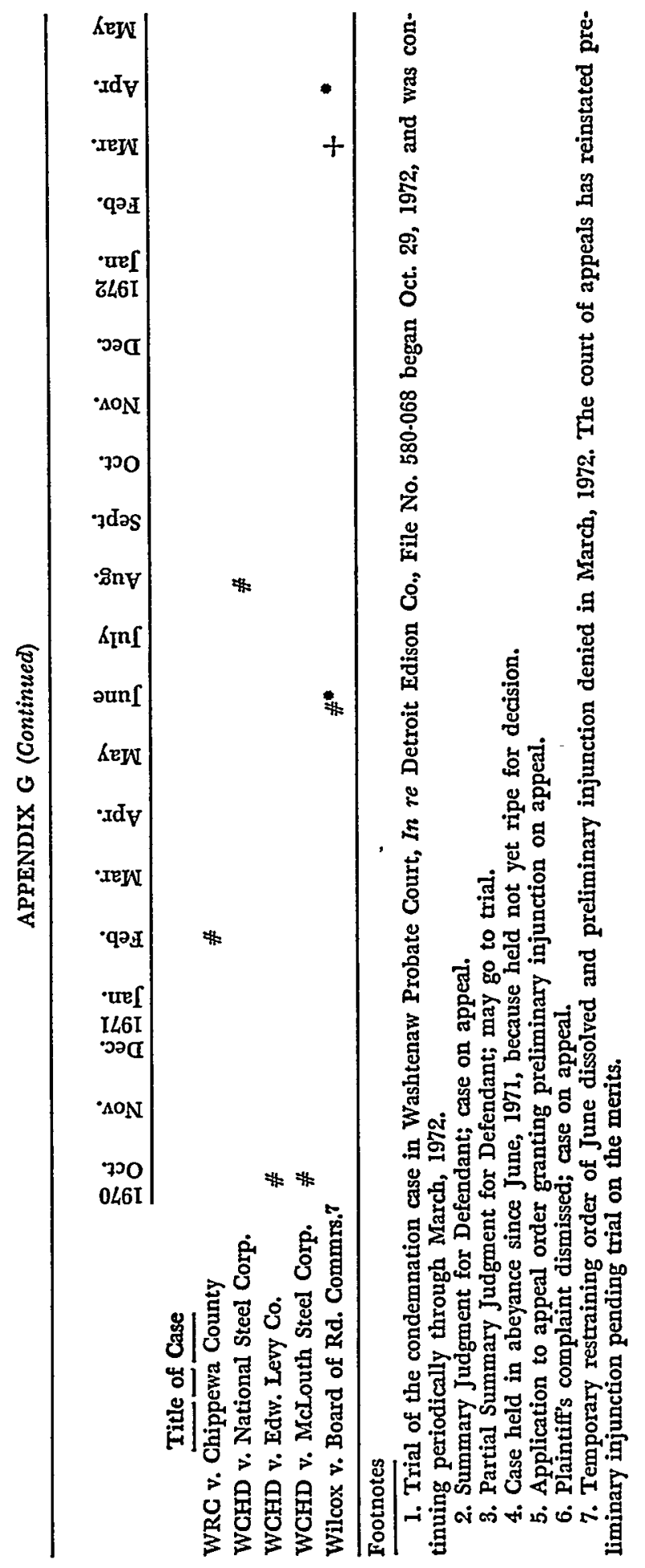




\section{APPENDIX $\mathrm{H}$}

Thomas J. Anderson, Gordon Rockwell Environmental Protection Act of 1970

Mich. Comp. Laws Ann. 691.1201-.1207 (Supp. 1972).

The People of the State of Michigan enact:

Sec. 1. This act, shall be known and may be cited as the "Thomas J. Anderson, Gordon Rockwell environmental protection act of 1970."

Sec. 2. (1) The attorney general, any political subdivision of the state, any instrumentality or agency of the state or of a political subdivision thereof, any person, partnership, corporation, association, organization or other legal entity may maintain an action in the circuit court having jurisdiction where the alleged violation occurred or is likely to occur for declaratory and equitable relief against the state, any political subdivision thereof, any instrumentality or agency of the state or of a political subdivision thereof, any person, partnership, corporation, association, organization or other legal entity for the protection of the air, water and other natural resources and the public trust therein from pollution, impairment or destruction.

(2) In granting relief provided by subsection (1) where there is involved a standard for pollution or for an anti-pollution device or procedure, fixed by rule or otherwise, by an instrumentality or agency of the state or a political subdivision thereof, the court may:

(a) Determine the validity, applicability and reasonableness of the standard.

(b) When a court finds a standard to be deficient, direct the adoption of a standard approved and specified by the court.

Sec. 2a. If the court has reasonable ground to doubt the solvency of the plaintiff or the plaintiff's ability to pay any cost or judgment which might be rendered against him in an action brought under this act the court may order the plaintiff to post a surety bond or cash not to exceed $\$ 500.00$.

Sec. 3. (1) When the plaintiff in the action has made a prima facie showing that the conduct of the defendant has, or is likely to pollute, impair or destroy the air, water or other natural resources or the public trust therein, the defendant may rebut the prima facie showing by the submission of evidence to the contrary. The defendant may also show, by way of an affirmative defense, that there is no feasible and prudent alternative to defendant's conduct and that such conduct is consistent with the promotion of the public health, safety and welfare in light of the state's paramount concern for the protection of its natural resources from pollution, impairment or destruction. Except as to the affirmative defense, the principles of burden of proof and weight of the evidence generally applicable in civil actions in the circuit courts shall apply to actions brought under this act. 
(2) The court may appoint a master or referee, who shall be a dis. interested person and technically qualified, to take testimony and make a record and a report of his findings to the court in the action.

(3) Costs may be apportioned to the parties if the interests of justice require.

Sec. 4. (1) The court may grant temporary and permanent equitable relief, or may impose conditions on the defendant that are required to protect the air, water and other natural resources or the public trust therein from pollution, impairment or destruction.

(2) If administrative, licensing or other proceedings are required or available to determine the legality of the defendant's conduct, the court may remit the parties to such proceedings, which proceedings shall be conducted in accordance with and subject to the provisions of Act No. 306 of the Public Acts of 1969, being sections 24.201 to 24.313 of the Compiled Laws of 1948. In so remitting the court may grant temporary equitable relief where necessary for the protection of the air, water and other natural resources or the public trust therein from pollution, impairment or destruction. In so remitting the court shall retain jurisdiction of the action pending completion thereof for the purpose of determining whether adequate protection from pollution, impairment or destruction has been afforded.

(3) Upon completion of such proceedings, the court shall adjudicate the impact of the defendant's conduct on the air, water or other natural resources and on the public trust therein in accordance with this act. In such adjudication the court may order that additional evidence be taken to the extent necessary to protect the rights recognized in this act.

(4) Where, as to any administrative, licensing or other proceeding, judicial review thereof is available, notwithstanding the provisions to the contrary of Act No. 306 of the Public Acts of 1969, pertaining to judicial review, the court originally taking jurisdiction shall maintain jurisdiction for purposes of judicial review.

Sec. 5. (1) Whenever administrative, licensing or other proceedings, and judicial review thereof are available by law, the agency or the court may permit the attorney general, any political subdivision of the state, any instrumentality or agency of the state or of a political subdivision thereof, any person, partnership, corporation, association, organization or other legal entity to intervene as a party on the filing of a pleading asserting that the proceeding or action for judicial review involves conduct which has, or which is likely to have, the effect of polluting, impairing or destroying the air, water or other natural resources or the public trust therein.

(2) In any such administrative, licensing or other proceedings, and in any judicial review thereof, any alleged pollution, impairment or destruction of the air, water or other natural resources or the public trust therein, shall be determined, and no conduct shall be authorized or approved which does, or is likely to have such effect so long as there 
is a feasible and prudent alternative consistent with the reasonable requirements of the public health, safety and welfare.

(3) The doctrines of collateral estoppel and res judicata may be applied by the court to prevent multiplicity of suits.

Sec. 6 . This act shall be supplementary to existing administrative and regulatory procedures provided by law.

Sec. 7. This act shall take effect October $1,1970$.

This act is ordered to take immediate effect. 


\section{APPENDIX I}

In February 1972 we sent questionnaires to all of the lawyers involved in EPA cases. We received thirty-three responses covering twenty-eight cases. The questions are reprinted in this Appendix along with a summary of the responses.

1. Were you able to obtain the kind of experts you needed to support client's case? If not (or if the difficulty was great) was the problem one of finding knowledgeable people? Too expensive? Unwilling to testify for your side of the case?

The following are excerpts from plaintiffs' replies:

The problem is that most of the experts in the field ... are employed by the defendant, and any other experts would have been too expensive.

We were unable to obtain a sanitary engineer willing to testify against other sanitary engineers-their livelihood depends on the favor of [defendants and others like him].

I have not had a great deal of trouble. . . . These people are, however, quite expensive. Many of the people who are in the air pollution consulting field with respect to engineering and control derive most of their income from consulting with polluters and are unwilling to testify. The only way I have been successful is by finding out who their principal employers are and using them to testify against other polluters and even then they are sometimes reluctant.

We had no difficulty whatsoever in securing expert testimony since we in effect were representing .... the interest of [a state agency]. Since [the agency] employs most of the experts with regard to the [problem area] in this stage, ... we were able to secure expert testimony without cost simply by subpoenaing those persons whom we knew had knowledge in the field.

We were able to obtain two expert witnesses who were willing to testify in our case without fee but only by deposition. . . . We did have considerable reluctance on the part of ... professors at [the universities] to get involved because they work so closely with the [agency involved].

\section{The following are excerpts from defendants' replies:}

We were able to obtain any experts we needed at modest cost. I am primarily engaged as counsel to the manufacturer and do not have any problems finding expert witnesses. The cost of such experts is high, i.e., $\$ 75.00$ per hour.

My client is an Intercounty Drainage Board. It is very difficult to find knowledgeable experts who are willing to testify on matters of this type either for the plaintiff or the defendant ... there is such a wide variety of what the experts agree and disagree upon, it is difficult to tell who to believe. 
2. If your client was an industry or government agency, did you find the lawsuit a serious impediment to your client's activities? Was there great delay? Did the court handle the case expeditiously? Did you view the case as an opportunity to vindicate a controversial program in the courtroom? How much delay (in months) did the case involve for your client?

Two thirds of the defendant attorneys who responded reported no significant delay in the handling of their cases and several specifically praised the courts' expeditious handling of the suits. Only one lawyer-of a dozen respondents-criticized a court's failure to schedule a trial promptly. One other lawyer noted that the trial court had acted promptly, but that a subsequent appeal had led to a delay of between six months and a year in resolving the controversy.

Several respondents, however, noted collateral delays arising out of the suits. One said: "The mere fact that there is litigation and an injunction will increase [contractors'] bids by at least twenty percent, as contractors are very leery of bidding on matters . . . when there is litigation involved." Another noted that the litigation had delayed ongoing negotiations between his client and the regulatory agency with which the client was dealing, commenting that "the moment that a suit is commenced the typical corporate reaction is to cease negotiations and fight the lawsuit." Interestingly, in this particular case, the regulatory agency with whom the client had been negotiating was itself the plaintiff.

Only one defendant's lawyer responded positively to the second question: "The suit was an excellent vehicle to resolve a very controversial issue-its final [decision] had a very settling effect on the affected persons."

3. In round numbers, how much did the case cost the client? $\$ 1,000$; $\$ 5,000 ; \$ 10,000 ; \$ 25,000 ;$ more?

Generally, how were these costs allocated, as between:

1) costs of obtaining expert opinion and studies?

2) depositions, travel and other out-of-pocket expenses?

3) attorney costs?

Give rough percentages.

The economics of EPA cases seem to break down into three general categories:

1. About ten per cent of the cases involve costs which are not directly measurable. These include a few cases in which an attorney sues as plaintiff pro se, and absorbs the costs in his general office expenses; cases in which public agencies are parties and do not cal- 
culate attorneys fees or out-of-pocket expenses separately, and in which there is often access to expert witnesses who work on salary for the public agency. In one case the attorney's fee is contingent on success in a companion damage case.

2. About a third of the cases have either been settled at an early stage or have not progressed beyond preliminary hearings and pretrial activities. Of the ten such cases on which we received responses, expenses in half were estimated to have run between $\$ 2,000$ and $\$ 2,500$. In the other half, expenses were estimated at between $\$ 4,000$ and $\$ 5,000$. The more expensive estimates generally represent cases that have involved a number of preliminary motions, a hearing on a preliminary injunction and some pre-trial discovery and conferences.

It seems a fair conclusion that a case that is settled fairly quickly without much courtroom action will probably not exceed $\$ 2,500$ in cost, assuming there is not a great deal of preliminary legal motion practice involved. A case that involves a preliminary injunction and other preparatory work short of a trial seems to average about $\$ 5,000$.

One exception to this observation inheres in the fact that most cases thus far have not been handled by "Wall Street" type law firms. We have only one response from such a firm, involving a case that has not gone to trial, but has involved somewhat more in the way of preliminary hearings and motions than the average such case just mentioned. The lawyer handling the case reported that his billings thus far were $\$ 15,000$ and that this fee was calculated at only half his regular billing rate.

3. In the third category are cases that have gone to full trial. The costs in such cases average about $\$ 10,000$, with a minimum cost of $\$ 5,000$ and a maximum of $\$ 12,500$.

The allocation of costs as between attorneys' fees, expert witnesses and other out-of-pocket expenses is directly related to the degree to which scientific issues are brought into the case. In the quick-settlement type of case referred to above-the $\$ 2,000$ cases-attorneys' fees amount to about ninety per cent of the costs.

Many of the cases that have gone to preliminary-injunction hearings and through some discovery-the $\$ 5,000$ cases-have involved very little use of experts. Thus the increased cost is attributed by lawyers largely to increased attorneys' time and to greater out-ofpocket expenses for transcripts and travel. A typical $\$ 5,000$ case would involve $\$ 3,000$ in lawyers' fees, $\$ 1,500$ in out-of-pocket costs, and $\$ 500$ for experts. 
As the cases go to trial, all costs increase of course, but the proportion devoted to expert costs increases most sharply. The average such case (in the $\$ 10,000$ range) will involve $\$ 5,000$ in lawyers' fees, $\$ 3,000$ in expert witness fees, and $\$ 2,000$ in out-of-pocket expenses. The range is from seventy per cent of costs for lawyers, twenty per cent for experts, and ten per cent for out-of-pocket costs, to thirty per cent of costs for lawyers, fifty per cent for experts, and twenty per cent in out-of-pocket expenses.

It seems clear that most private litigants thus far have under-used experts in terms of the objective requirements of the case; and a number of responding attorneys have noted the high cost of expert witnesses. Thus it might be concluded that the costs of litigation noted above would probably be doubled if the lawyers used as much expert help as they truly needed. An average case prior to trial would jump in cost from about $\$ 5,000$ to $\$ 10,000$; and a case taken to full trial would cost about $\$ 20,000$ rather than $\$ 10,000$. Litigants using big-city, large corporate firms (unless they get a bargain) can expect their costs to be more than twice this much; that is, a full trial, properly conducted, involving extensive expert testimony, can be expected to run from $\$ 40,000$ to $\$ 50,000$.

4. Was the judge able to understand and handle the environmental, scientific and technical issues? Greater, less or about the same problems of comprehension as in accident, commercial, corporate cases?

Sixty per cent of the respondents reported that the judge understood the scientific, technical and environmental issues. Only ten per cent said the judge had more problems of understanding than in the ordinary case, and the rest found that the judge had "a little problem" of understanding, but no greater than in the ordinary case. Excerpts from some of the responses follow:

The Court has shown unusual ability to understand and handle the legal, scientific, and technical issues involved. (Agency lawyer)

I doubt that the judge was able to handle the principal [legal] issue involved. In my judgment it was a very simple issue, ... and ... the opinion denying plaintiff's motion made no sense in terms of the briefs ... presented. (Plaintiff's counsel)

The problem with 127 [the EPA] is the need in each case to educate the judge on often highly technical matters. (Agency lawyer)

Judge probably has as good a grasp on issues as in other cases. (Defendant's counsel)

I think the judge was able to understand the issues. (Defendant's counsel) 
(The following two responses are from a winning plaintiff and a losing defendant, respectively, in the same case.)

I have seen judges show less comprehension of [ordinary] personal injury cases. [The judge] showed a comprehension borne of attentiveness devoutly to be wished for in other cases.

I believe that the trial judge was not as familiar with the scientific and technical aspects as he would be in the case of accident ... cases.

5. If your case involved an industry or an administrative or regulatory agency, do you think the case has affected their general way of doing business, or their attitude toward environmental issues, in any significant way? Please be as specific as possible. (E.g., the agency has tightened up its procedures for giving variances; it has hired some new staff with environmental expertise).

A bare majority of the respondents felt a defendant public agency's behavior had been affected by the suit. In one case industry behavior was said to be affected by the litigation. Several respondents wrote that it was too early to say. Comments include the following:

[The agency] won't do this again on ad hoc information from the government-[it] will require some flow data on stream, and may even get some legal advice before signing something it might regret. (Plaintiff)

[We] proved it [the agency] had insufficient data. [We] hear rumors that it was embarrassed. Certainly it will get data before granting any more such permits-[the case] may have resulted in a major change of position. (Plaintiff)

I heard various rumors indicating that it forced the agency to tighten up its procedures for granting variances while other rumors indicated that it had no effect. I am convinced ... that because the agency viewed the suit as frivolous or otherwise unjust that it will favor the polluter on any position taken by it if it possibly can. (Plaintiff)

I announced concurrently with commencing the litigation that I would dismiss it if [the defendant] would agree to join the waste water plan.... They did join the plan ten days or two weeks [later]. While $I$ am sure that the ... litigation was not the only factor which compelled reconsideration of their position, I feel that it probably played some part and such part may possibly have been decisive. (Plaintiff)

None of these cases has resulted in a tightening up of any attitude except [one case which] I believe is much to do about nothing. (Agency)

Speaking from the agency standpoint, it has made them more careful in documenting their positions and more careful re initial actions (what is said in a letter or in a meeting). I see no result regarding attitude on policy and purposes. (Agency) 
In my view, the pending litigation has materially affected their attitudes toward environmental issues. Both of the agencies have tightened up their procedures for the handling of contaminating wastes. (Agency)

Since our plant was an industry, specifically the case substantially affected the way of doing business since it terminated its business activities. (Defendant)

The State ... Department is now providing means to [deal with the problem so that the issue raised in the case will not arise again]. While denying any connection [with the harm] or liability, they are very, very aware of the problem. (Defendant)

The suit was an excellent vehicle to resolve a very controversial issue-its final determination had a very settling effect on the affected parties. ... I think the [federal and state] agencies welcomed the opportunity to get the controversy resolved. It took the pressure off them since the Court's decision was well accepted and practically eliminated further complaints. (Agency)

6. If your client was a plaintiff, could you have sought the relief you wanted without the EPA? E.g., could nuisance law or a claim under another statute have done the job? Was the EPA indispensible as to standing-to-sue?

The EPA was said to be necessary in ten cases, and alternatives would have been uncertain or created difficulties of proof in three others. In three cases respondents felt that an alternative ground, such as nuisance, could have been the basis for the action. Excerpts from some of the responses follow:

Answering from the point of view of the ... defendant; this plaintiff would have no standing to sue without the E.P.A.

. . . A similar suit was started several years ago in Houghton County and the case was dismissed summarily because the court found there was no authority under Michigan law to entertain such a suit.

... [I]t would appear that the nuisance law would have been sufficient to get the relief obtained. .. The EPA was helpful in this case however because the intervening plaintiffs residents could put pressure on the administrative agency, which could not have been done in a nuisance suit.

No [we could not have sought the relief] except [as to] the Riparians. Note that we brought them in under EPA so as to get the protection of the bond limitation.

$\therefore .[P]$ laintiff could not have effectively sought the equitable relief requested without the EPA. It is clear that we could not obtain this relief under theories of common law nuisance, or by proceeding under Act 245 of the Michigan Public Acts of 1929, as amended.

Judicial redetermination of the WRC standards could not have been had without the EPA. However, the principal relief sought ... was available under common law and other statutes. ... 
.. Nuisance law would have done the job with respect to damages but probably would not have afforded as good a level for injunctive relief. I have not yet filed a case in which the EPA was indispensable as to standing.

The Environmental Protection Act was essential in this case since the Drain Code provides very little avenue of appeal from decisions of the Drain Commissioner, whether environmental or not.

With regard to the EPA specifically, this represents but one count of our lawsuit. In addition we have alleged that the project constitutes a violation of the common law riparian rights of other proprietors in the area as an unreasonable overuse of riparian property and that it violates a local Zoning Ordinance. At various stages in the lawsuit the various claims have assumed different relative positions of importance. It is our opinion that the EPA did provide initial access to the Court for the individual Plaintiffs that could not otherwise have been obtained by them. We regard the granting of standing to individuals to sue for present or future damage to the environment as one of the major accomplishments of our legislature in the recent past. ...

EPA was essential to joining the State ... Department in this case.

7. The EPA was drafted to be as concise as possible. Was this a mistake? Do you find the statute too cryptic? Does its brevity help to cut down time-consuming litigation over details, or increase it?

A sample of the comments follows:

I do not think it was a mistake to keep this statute brief and concise. ... One of the arguments made by the Attorney General's office in their motion for a summary judgment was that attempting to enjoin [the agency] from issuing ... permits does not come under the statute. The court specifically found that this was a proper object under the statute. (Plaintiff)

I thought in my particular case ... the statute was clear. ... [R] egardless of how a statute is drafted the first few years of litigation under it always require ironing out procedural matters. (Plaintiff)

[A] possible problem . . . is . . that, in suing an administrative agency, the Courts may incorporate some of the old appellate review standards such as "whether the findings were supported by the law. ..." (Plaintiff)

The EPA was drafted in a concise manner and perhaps this is the best way to start. I am not in a position at this time to say that there should be any amendments. We need to obtain some Court decisions and then determine the direction of where our efforts and pressures should be put. Case by case method appears to be the best. (Plaintiff)

I think the [EPA] was drafted in too concise [of a] manner and I en- 
vision that this will be apparent as time goes along. It is my position that there will need to be a substantial amount of legal precedent before the statute is finally settled in its niche and I don't believe the brevity of it is going to cut down on time-consuming litigation. (Defendant)

The EPA is a definite benefit to plaintiffs filing suit under it. It allows for very little quibbling over procedural details and forces the parties to get to the merits of the case. (Plaintiff)

The statute is too indefinite to be of any value. I am of the personal opinion that it is unconstitutional, as it delegates complete powers to the judge to set up regulations and standards without any guidelines. (Defendant)

It is not too cryptic. I believe it does help cut down time-consuming litigation. (Defendant)

It is too cryptic. Litigation . . . doesn't come about because of too many details, but because people who have to spend money to comply with the law will ... fight whenever it costs less to fight than to comply. (Defendant)

8. In general have you found judges sympathetic, hostile, or neutral on the goals of the EPA?

Thirteen judges were found to be "sympathetic" to the goals of the Act; thirteen "neutral," three "hostile," and one "really didn't want to get involved."

9. Any other comments? (We need a provision for attorneys' fees; the provision on bonds is helpful, harmful? The venue provision creates problems, etc.).

Concerning the bond requirement $(\S 2 \mathrm{a})$, the lawyers responded as follows:

The provision with respect to a bond is neither helpful nor harmful. While my client was never requested to put up a bond it could have done so easily and since the bond requirement is so minimal the willingness of a plaintiff to put up a bond may have some influence on a judge. (Plaintiff)

This is a double edged sword. The low limit is helpful because without it I think few cases would be started. On the other hand, it may lead some judges to refuse to issue TRO's or preliminary injunctions. (Plaintiff)

The bond provision has merit and should be continued in order to prevent harassment by litigious plaintiffs. (Defendant)

I understand [the bond provision's] purpose but believe it does cause injustice as to a private defendant who is subject to great financial loss because of delays, etc. (Agency lawyer)

Provision on bonds may be contrary to equal protection notions. (Plaintiff)

The provision on bonds is extremely helpful since none of the parties plaintiff in [EPA] suits whom I have represented have had 
the wherewithal to pay any substantial bond fee and might well have been precluded from achieving any relief by way of preliminary injunction if the bond maximum had not been set by the statute. (Plaintiff)

Four lawyers gave unqualified support to a provision allowing attorneys' fees to be awarded to the prevailing party; another found the idea "intriguing"; and three others offered more extended discussions:

I would be careful about attorney fees. Very careful. I don't want them being assessed against plaintiffs when a public question is involved. While the experts are expensive, their expense limits vexatious suits. If costs could include attorneys fees and be assessed only if defendant loses, who would buy that? Necessarily these actions will be self-limiting because of expenses and attorneys fees. Many attorneys will have to be at least partially pro bono, as I have been .... We need a state bar section of EPA-type attorneys. (Plaintiff)

[A good idea] as long as it only works one wayl It would obviously stimulate suits. Too soon for this, in my opinion, in Michigan. (Plaintiff)

In our judgment, the [EPA] opens the door to a plague of law suits in which any defendant needs protection from expense . . . . [W] hen the suits are brought, redress should be available for the defendant to recoup its legal and financial expenses and losses resulting from the litigation if the defendant prevails. (Defendant) 